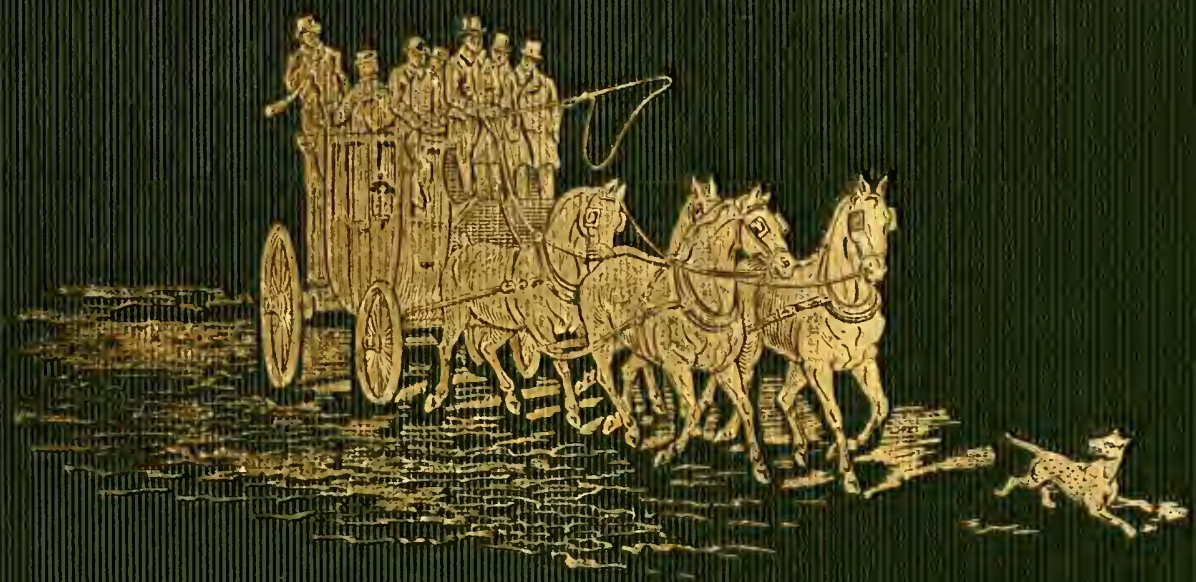




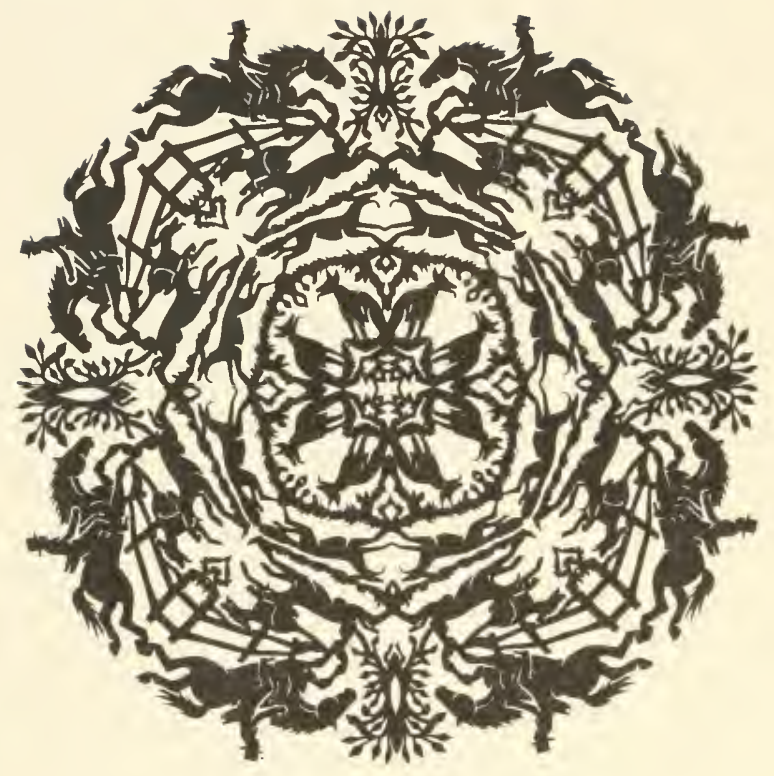

\section{JOHN A.SEAVERNS}




\section{Vetertnary Lborary}

Tutrs University

School of Veterinary Medicine 200 Westboro Rd.

North Grafton BAA ?...s 

This Edition is limited to 500 copies 



\section{THE AUTOBIOGRAPHY OF A STAGE COACHMAN}






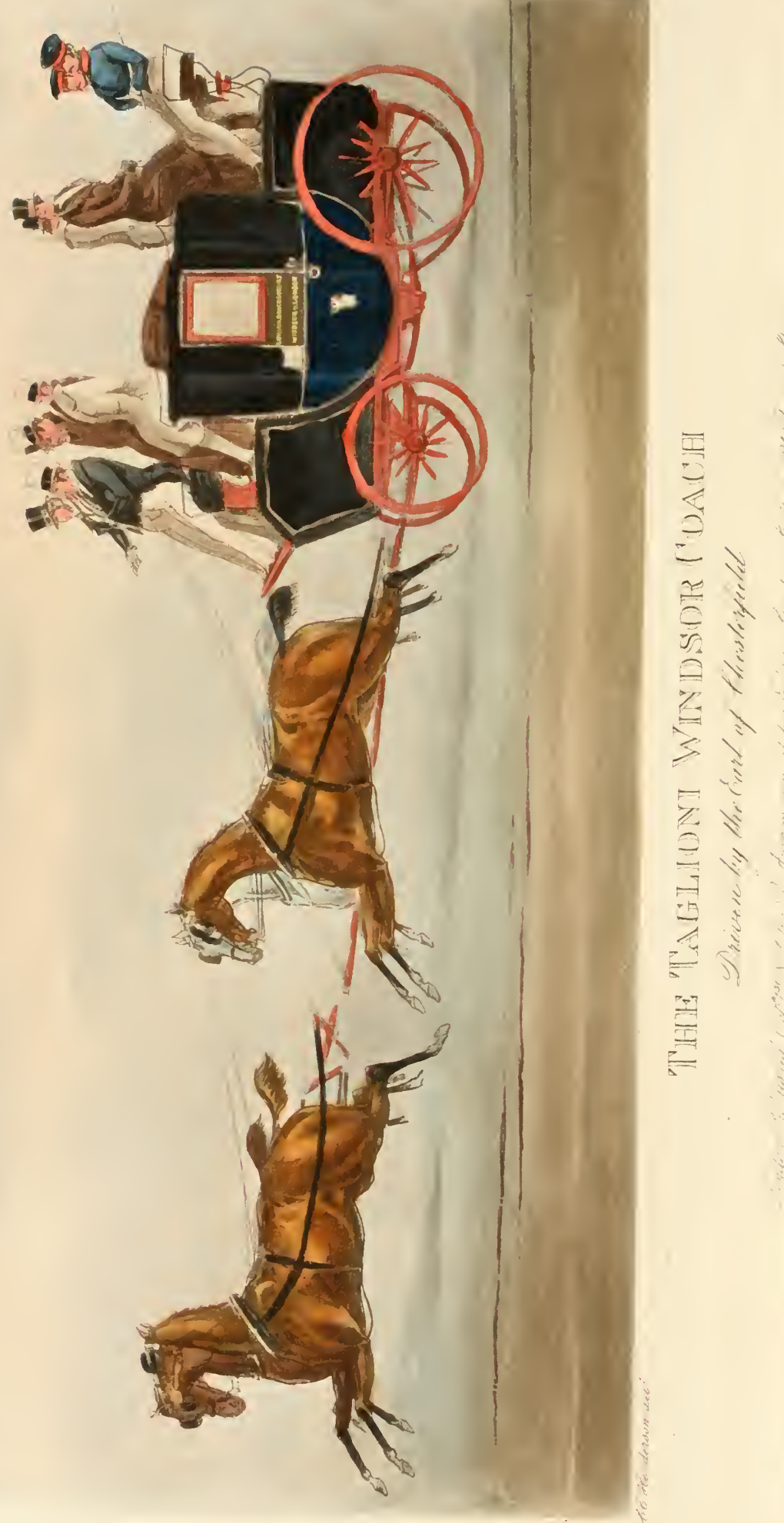




\section{THE AUTOBIOGRAPHY \\ OF A \\ STAGE COACHMAN \\ BI \\ THOMAS CROSS \\ Illustrated With 43 Plites by James Pollard, Robert Havelu, C. Cooper Hexdersox, C. B. Newhouse \\ Thomas Rowlaxdson, H. Alnex \\ AND OTHERS}

IN TWO VOLUMES

VOL. I.

LONDON

KEGAN PAUL, TRENCH, TRÜBNER \& CO. LtD.

Drydex House, 43, Gerrard Street, W.

1901 


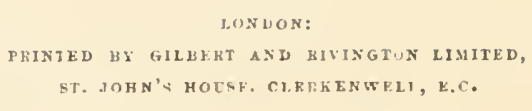


то

HENRY VILLEBOIS, ESQ.

THESE PAGES

ARE

BY PERMISSION

MOST RESPECTFULLY

AND GRATEFULLY DEDICATED

BY

THE AUTHOR 



\section{PREFACE}

IF in the perusal of this narrative it should be objected that there is fir too much of a personal or private nature, the author's excuse is, that it was commenced to gratify a large circle, beyond whose limits it was never intended to pass; but some friends, thinking it worthy of a more extended circulation, have induced him to offer it to the public.

If it should be found not altogether to correspond with the title, and here and there to treat of persons and things in a manner not warranted by the position of the author, he claims the privilege of free agency, and shelters himself under the shadow of precedent.

In the Autobiography of a Stage Coachman the reader must not expect to find any exalted sentiment, any imaginary tale, any burlesque review, or any very deep pathos; discursive as it may be, no caricature of ereryday life, no pungent satire on the follies or fashions of the day, enlivens its pages--they contain merely a plain, unsophisticated detail of incidents and occurrences that came under the observation of a man who had daily intercourse with all classes of people. 



\title{
CONTENTS OF TOL. I.
}

\author{
CHAPTER I \\ A Novel Commencement-A London Coach-office-A Country \\ one-A Provincial Book-keeper-Lord Bacon-Shakspere \\ - Lord Byron-Inquisitiveness-An Important Confes- \\ sion-A Father-A Mother-A Prognostic-Alexander \\ Pope-The Itchen-A Scene in Hampshire-Gibbon-A \\ Popular Divine-A Tyrannical Pedagogue-An Instructor \\ of Youth-A Long Ride-A Hasty Decision . . . \\ PAGE
}

\section{CHAPTER II}

The Departure and Outfit-A Fourth-rate Man-of-WarCaptain, Officers, and Crew-Sea-sickness-The Quarterdeck-The Cock-pit-An Accident-Lubbers' Hole-The Schoolmaster-Midshipmen-Rio de Janeiro-An Extraordinary Feat-A False Alarm--The Captain's Table-A Court-martial, Sentence, and Execution-Scenes in the Gun-room and in the Captain's Cabin-A Pleasant Time - The Middle Watch-Fore and Afternoon WatchesThe First Lieutenant-Corporal Punishment-The Haven

\section{CHAPTER III}

Day-Dreams-The Shark and the Dolphin-Yarns-A Hard Hit-The Armourer's Chest-Calcutta-The Marquis Wellesley-The Return-Madras-A Scene in the Water -Trincomalee and Colombo-Bombay and ElephantaThe Straits of Sumatra, and the Captain's Advice-China Seas-A Typhoon-Canton - A Distinguished Naval Officer-Parting-An Historical Comparison-An Agreeable Shipmate-St. Helena-The Chops of the ChannelThe Pilot Boat-A Polite Request-The Landing-Sentiment . 


\section{CHAPTER IV}

A Coach Proprietor-Members of Parliament-A WelcomeNelson's Funeral-The Theatres-George Frederick Cooke - John Kemble and Mrs. Siddons-The Country-A Death-bed Scene-An Elegy--The Lawyer-A Second Blow-The Wine Merchant-A Third Blow-A Valetudinarian-The Postmaster-A Scene at the Dinner-table -A Consultation and Trial-Unexpected Result-Philanthropy . . . . . . . .

\section{CHAPTER T}

Convalescence-Thoughts for the Future-The Sixth MateAmusements - A Rash Adrenture-A Literary SocietyJunius-Lord Macaulay-A Character-A Fire-Gunpowder Companionship-Cord Gambier-_Sir Eliab Harvey - Sir Roger Curtis-Lord Cochrane-A Curious Rencontre-The Prince of Wales-A Dreadful ExplosionWonderful Escape-A Rash Attempt

\section{CHAPTER VI}

Younger Sister-Pleasant Gallop-Younger Brother-Pleasant Swin-Dreadful Disastel at Sea-A Naval Ball-Selfconfidence-Domestic Sorrow-New Branch of an Old Acquaintance-Career of an Officer-A Distressed Mother, her Trials and her Death-Pleasant Life-A Welcome Visitor-Sad Calamity-A Trio-Duel-Pleasant Body Companion-The Comets of 18.58 and of 1811-Description of-Astronomers

\section{CHAPTER VII}

The New Forest-The Confines of Dorset-A Country Town -Shooting - Lord Chancellor Eldon - Encombe-Sir Walter Raleigh — Smoking - Lulworth - Corfe CastleEdward the Martyr-King John-Lady Bankes-The Heroes of the Parliamentary Army-Christian Preachers -Education-An Original Sect-A Legend-The Isle of Wight-The Royal Cockpit-A Joke-The Duke of Deron- 
shire-Two Foreign Princes-A Prince of Coach Proprietors-Friend in Need-A False Step-An Establishment - Wedding-Breach of the Law-Mr. Justice Burroughs - Soberton Downs-An Israelite Sportsman-A Bet-A Fracas-Lawsuit_Judge Gazelee-A Dispute on a Point of Law-1Ir. Serjeant Pell

\section{CHAPTER VIII}

The War-Trafalgar-Sir John Moore-Sir David BairdCorunna-Disembarkation-Walcheren-Camp at Southsea-Embarkation-The Earl of Chatham-Sir Richard John Strachan-Prosperity of Seaport Towns-A Profitable Business-A Distinguished Military Gentleman; his Wants Supplied-A Dinner and Wine-The Bill-An Interesting Discovery-Drive to Reading and Oxford-An Agreeable Surprise - Prompt Resolve-Clouds in the Distance-The Russian Campaign-The Campaign in Germany-Peace-The Visit to Portsmouth-Insanity of the People-Prince Blucher-The Emperor Alexander —The King of Prussia-Napoleon . . . . .

\section{CHAPTER IX}

A Long Frost-Fair on the Thames-Journey to the NorthGuinea Pigs-A Younger Brother-Charming Domicile -Edinburgh-Messrs. J. \& J. Ballantyne-Departure - Deep Snow-Pleasant Ride by Moonlight_CarlisleLiverpool-Delightful Companions-A Morning's WalkPeace-Two False Steps-A Master of Hounds-Our Peoples - Scene in a Wood-A Yorkshire Tyke-Laughing Philosophy - Whitechapel — Somerset House - Portsmouth Dockyard-The Commissioner . . . .

\section{CHAPTER $\mathrm{X}$}

A Wet Season-Beneficial Farming-A Racing Stud-A Commissary-Petworth-Duke of Somerset-Seymour the Painter-Scene in a Brook-An Alarming Purchase-Contagion-Pathology-Naval Captain-Domestic Calamity - Alterations and Improvements-An Unblushing Villain -Driving Clubs-A Saturnalia-Comparison-An Attraction-A Final Resolution . 
Ambition-The Beetle-Loss of Caste-The Brighton Road -Box Companions-A Naval Hero-Sporting ColonelR. B. Sheridan-New Friends-A Race-The ResultFog-Singular Appearance - Talkative Companion - A Spill-Scene in the Bere Forest-Unrewarded FriendsExperience-An Exeat . . . . . . . 218

\section{CHAPTER XII}

Amor Patrix-Domestic Arrangement-Emery-A Revolution -Education-A Swell Dragsman-Contrast_Leamington -A Proposition-Warwick Castle-Stoneleigh Abbey and Kenilworth-An Agreeable Surprise-A New Start-Idle Hours - A Country Walk-Gorhambury-A Pleasing Adventure - Sir Harbottle Grimstone and Lord Bacon again-Reflections and a Reflection-An Invitation-The Consequences-A Scene at South Mimms . . . $23 \pm$ 


\title{
LIS'I OF PLA'TES
}

\author{
TO TOL. I.
}

PAGE

1. The Taglioni Windsor Coach, by C. Cooper Hexderson Frontispiece

2. Royat, Malls startixg froji the Post Office, by S. J. E. Joxes . . . . . . . . To fuce 1

3. Arrival of the Stage Coach, by Jayes Pollard . " 3

4. Stage Coach Travellixg, by James Pollard . . , " 15

5. A Loxdoy Mall ayd Stage Coach, by Robert Harell , $6: 3$

6. Loxdox, Dover, axd Deal Солch, by H. Vernet • " 81

7. Puttixg-up a Cock-fight ox the Road, by H. Alkex , 94

8. Stage Coach Passengers at Breakfast, Redbours, by Jajes Pollard . . . . . . . . . . 153

9. The Readixg Telegraph Coach, by Robert Havell . „ 158

10. The Allied Sotereigss attexdixg a Peviet, 1814, by A. SAEERWIED . . . . . . . . " 167

11. Extraordixary Exploit derixg the Erost, by Iygrey AXD NADELEY . . . . . . . . . . , . 173

12. The Sxowstory-Delay of the MaIl, by JaMes

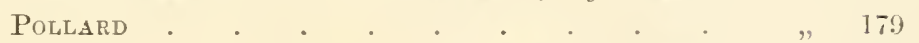

13. The MaIl CoAch ix a Drift of Sxom, by .Jayes Pollard . . . . . . . . . . , . 1 . 1

14. The York Highflyer Coach, by Mr. Emery • . " , 209

15. Four-ix-Haxd at "The Rokbuck," by James Pollard "

16. Sotthamptos Coaches-The Telegraph, by C. B. Nemhotse. . . . . . . . . . . . . 213

17. The Prymouth Fly, by Thomas Rowlaxdsox . . " 215

18. "The Age" Brightox Coach at The "Bull axd Moctir," Regext Circes, Prccadilir, by E. F.

LAMBERT . . . . . . . . . . . . . . 
xir LIS'T OF PLA'TES

PAGE

19. The Opposition Coaches, by C. Cooper Hexdersox . To fuce 228 20. "The Blenheim" Coach leavisg the Star Hotel, OXford, by George Havelal . . . . . , 237

Woodcuts in the Text

The Glory of the Age (Steverson), ly "Wildrake" . page 202.2 A Clefar Stage axd yo Favol"r, by "Wildrake" . . " 2.53 



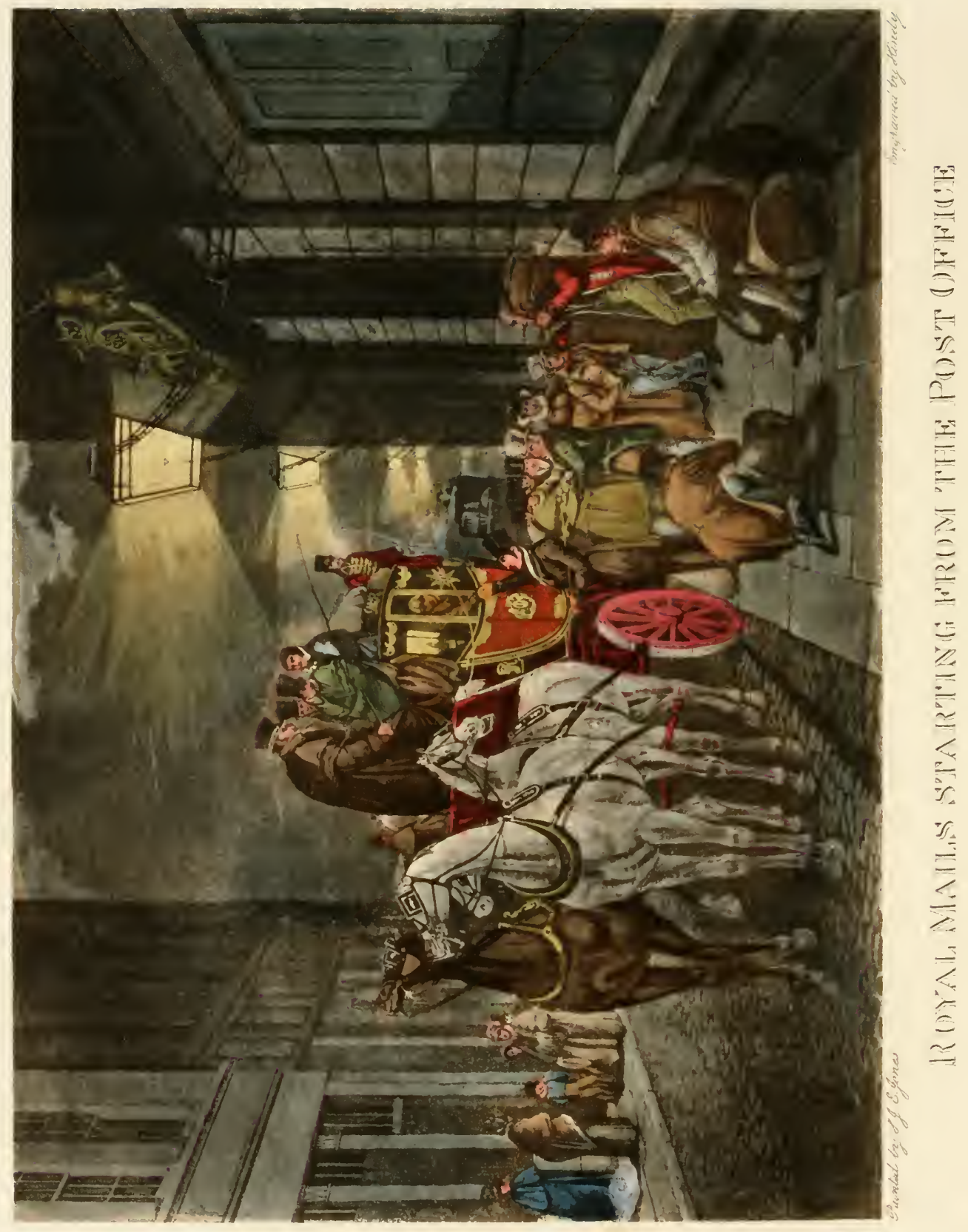




\title{
THE AUTOBIOGRAPHY OF A STAGE COACHMAN
}

\author{
CHAPTER I \\ BIRTH, PARENTAGE, AND EDUCATION
}

A Novel Commencement-A London Coach-office-A Country one -A Provincial Book-keeper-Lord Bacon-Shaksper̨e-Lord Byron-Inquisitiveness-An Important Confession-A Father -A Mother-A Prognostic-Alexander Pope-The Itchen-A Scene in Hampshire-Gibbon-A Popular Divine-A Tyrannical Pedagogue-An Instructor of Youth-A Long Ride-A Hasty Decision.

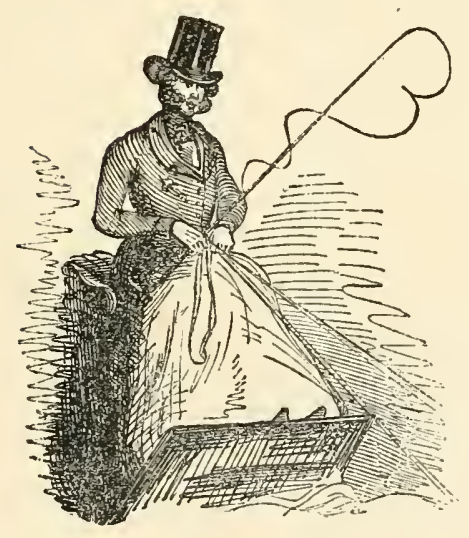

EFORE the new method of travelling had quite superseded the old, when railways had not become so general as they now are, the establishment of the main or trunk lines had dispossessed those men of their seats whose names were as familiar as household words, when associated with the requirements, the business, and the pleasures of the community; and had driven them, like the ancient Britons, to the mountainous districts of VOL. I. 
Wales and Cornwall, or to the swamps and fens of the opposite side of our island, to follow their vocation, and to seek their subsistence.

It was then the fate of the author of this narrative to be engaged in driving a coach from one of the seaports on the eastern coast, where the enemy had not yet penetrated, but to which he bid fair soon to be a velcome visitor.

One cold, dark winter morning, a little before day, in the last decade of the first half of this present nineteenth century (ny memory will not serve to state the precise year), I was walking leisurely from my lodgings, with my great-coat over my left arm, and my four-hor'se whip in my right hand, to the inn from which the coach daily took its departure.

On that particular morning some serious thoughts had arisen in my mind; and a hasty retrospect of my early days, contrasting strongly with the gloomy prospect before me, passed through my brain.

In London, the half-hour preceding the starting of perhaps five or six coaches from any of the large establishments, was a time of some little excitement. The neat and elegant Telegraph Coach, with its polished boot, on the hinder part of which was inscribed, in large characters, "The Times," "The Independent," "The Wonder," or some such appropriate name; the highlyvarnished body, the blazing Golden Cross or the Spread Eagle conspicuous on the door panels; the motley crowd of people, of both sexes and all ranks, from the peer to the humble mechanic, some anxious to take their seats in or on these delightful conveyances; the well-groomed cattle, 


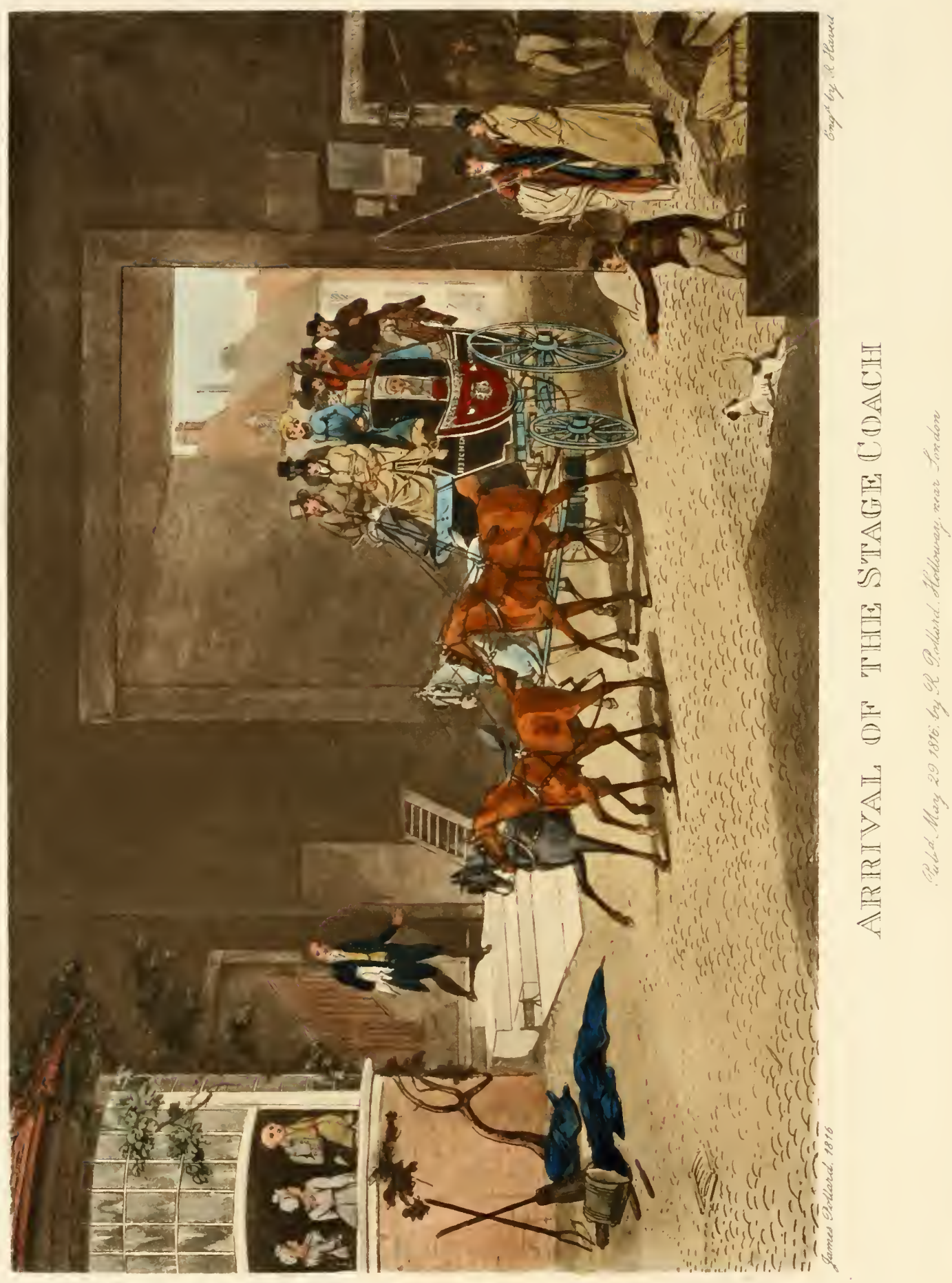


with their attendant horsekeeper, the harness all in the nicest order ; the quantity of packages issuing from the booking-office; the instructions, not unmixed with a little good-natured banter, vulgarly called chaff, given by the book-keeper to the well-known characters about to proceed to their accustomed destination, formed altogether a scene not unworthty the pen or pencil of a Hogarth.

How different the same half-hour in a provincial town in one corner of the kingdom. On approaching the inn not a solitary person did I see. The dingy, half-rvashed coach stood by itself outside the gates, like a deserted ship; inside the yard there was a dim, dirty place set aside for the office; in it glimmered one poor mutton candle, stuck on a piece of rusty tin, that had served the ostler for a candlestick for years; by its light I entered, and could just perceive a lantern-jawed, melancholylooking man, whose visage indicated-indeed, seemed already to anticipate - the fate that awaited both him and me, leaning with his head upon his hand, inert and heedless, as most men are who have nothing to do-this was the porter. On the other side of the counter, behind an old worm-eaten desk, sat the book-keeper. The usual salutation having passed between us, I took from the desk a long sheet of white paper, which, with the exception of the leading, was unsullied-not the name of a passenger or parcel was written thereoin! This was what is technically called the "way-bill." With a complacency I could sometimes assume, I read the date aloud, adding thereto that it was a most remarkable day. 
"Remarkable, Mr. C-_, for what?" said my inquisitive friend, the book-keeper.

"Remarkable, Mr. B__," I repeated, "for its being the natal day, or, more properly speaking, the anniversary of the birth of three celebrated men."

"Indeed! Pray, who were they?"

"Why, Mr. B_—," I said, "the first was a man of most profound wisdom and learning-one of the great luminaries of the Elizabethan age-a scholar, an orator, a lawyer, a statesman, a philosopher; the first, indeed, of his age and country, and one to whom the nation and mankind in general are much indebted; but I am sorry," I said, "to be obliged to add, that his fame was sullied by one of the meanest of vices."

"Indeed, Mr. C-—, you surprise me; why, who could that be?"

"Francis Bacon, Baron Verulam, Viscount St. Albans," I replied.

"Oh, yes! I have heard of him. I have read a great deal about him; he was, indeed, a great man."

"Yes," I continued, for the dreariness of the morning, and the lack of clients, induced the conversation, or, in an old sea-phrase, I had my javing-tackle on board; "yes, and it is stated by some ${ }^{1}$ that he has been robbed of half his fame-that posterity has given to another a renown that has filled the universe-which ought to have belonged to this great man. Yes, sir, from some unknown, and now for ever hidden cause, they seem to

1. It was about this time the hypothesis of Lord Bacon's being the author of some, at least, of Shakspere's Plays, first made its appearance in the Northern capital. 
argue, that the most capacious mind, the most comprehensive learning, the most fertile imagination, and the most perfect knowledge of the human heart-its springs, motives, and actions, together with the most masterly design, the most eloquent diction, and the most dignified sentiments that the English language ever expressed were produced by the son of a third-rate tradesman in a small provincial town."

"Indeed! Well, I know nothing about that."

"Neither do I, Mr. B-, enough for me that the writings are the product of our language, and will ever be its pride and boast; and though 'Palmam qui meruit ferat' is a very good motto, I would rather pass it by and forego a controversy that might tend to disturb the wreath on a brow the entire civilized world has combined to honour."

"I do not exactly understand what you say; but pray tell me who was the second?"

Now, this book-keeper was a respectable tradesman in the town, and had attended this particular coach only, in that capacity, it being originally a subscription-coach and had so remained for many years.

"Why, my dear sir," I said to him, "I fear you will not like the second quite so well." I knew my friend to be a strict religionist, of the Wesleyan persuasion. "The second who claims this as his natal day," I said, "Mr. B-_ was a writer who, in our days, has been almost idolized; his works have been much admired, and he has obtained extraordinary fame as a poet. It has been objected that some of his poems have rather a loose tendency; but his was a master-spirit-he possessed a 
vigorous understanding and a creative fancy-somewhat tainted with a misanthropic egotism, it must be admitted. His principal weapon was satire, and he handled it with more power than discretion; nevertheless his works will continue to be read by every real lover of poetry, and will for many generations amuse and delight, if not instruct, the masses."

"Who was he, Mr. C-_- ?"

"George Gordon Byron-Lord Byron."

My friend started, and exclaimed,-

"Oh! ah! I do not think so much of him as I do of the other; he has not added much to the moral or religious tenor of our literature."

I was about to argue this point with him, as Mr. Midshipman Easy would say, when he stopped me by asking, who the third was?

"Well, my dear sir, as the clock is about to strike, and it will take me some time to introduce the third to your notice, I must defer it till I see you again."

So, putting on my coat, in which I was assisted by the taciturn porter, I folded up the way-bill, and carefully placed it in my pocket; then walked out, took hold of the reins - the horses being already put to-mounted the box, wished him good morning, and drove off.

The following evening, on my return, he pressed me very hard to tell him who the third celebrated person was to whom I had alluded. I made some excuseeither I had not time then, or I said I hoped he would have discovered it himself; but he never did, nor did I ever tell him, although he repeatedly asked me; and I 
verily believe he went to his grave uninformed on such a very material point. But, gentle reader, that you may not remain in ignorance of so remarkable a coincidence, one absolutely necessary to give importance to this autobiography, I must confess that $I$ was that third person, and must leave it to you to question, pardon, or condemn, the humorous vanity which induced me thus to provoke the curiosity of a simple and inquisitive mind. Yes, on the 22nd of January, in the year 179 - in the ancient and renowned city of Winchester, I first made my appearance on this world's stage, the third of a family that in due time amounted to thirteen.

Should the reader's curiosity be further aroused to wish to know anything of the parentage or genealogy of the humble individual who has thus obtruded himself on his notice, little can be said to gratify it, for little is known to himself. My father, I always understood, was left a penniless orphan when very young. To whose care he was entrusted in his infancy, or how his youth was passed, I never correctly knew; but in mature life, by dint of industry and persererance, aided by fortuitous circumstances, he has amassed considerable wealth, and had obtained a position in one of the southern counties that his son has long contemplated with unavailing regret, where he, for a time, exercised all the functions, and enjoyed all the social benefits, belonging to the life of a country gentleman-hospitably entertaining a large circle of friends, and by his constant and liberal employment of the poor, commanding their good word and esteem.

Ingratitude, it is said, is inherent in the heart of 
man; but when the remains of my father were brought a long distance to be interred in a vault he had built years before for his remains and those of his family, the attendance of the aged villagers, their expressions of respectful remembrance, with their recapitulation of the good he had done when living among them, might, I think, be quoted as an exception.

My mother's patronymic, although herself of humble birth, was the same as that of a family who had been ennobled in the time of the first Charles; and a tradition had obtained currency amongst us that she was of the same extraction. This was partly corroborated by a gentleman of this name who, once calling on my father, appeared to me, by his conversation, to be the connecting link between the holder of the title and his far-off and more humble cousins. He bore the commission of Major in one of the Midland Counties militia regiments. I never took any trouble to trace our relationship with this exalted family, but if a noble expression of countenance and personal accomplishments of the highest order were proofs of the alleged descent, my mother possessed them in an eminent degree. "She looked like a duchess?" as a friend of mine said to me, when wishing to explain the impression she made upon him when he first beheld her. But I may be allowed to say she possessed a far better and juster claim to nobility than either birth, descent, or appearance could give. Exemplary in the performance of all the duties of domestic life, the faith of a true Christian dwelt in her heart, and animated all her actions; and this was daily exemplified either by attention to the requirements of the poor, or by 
kneeling at the bedside of the sick and dying. I remember when telling a long-absent friend, and one who knew her well, of the place, time, and manner of her death, "Then, sir," said he to me, "departed one of God's best-created beings." She died before a sad fatality buried all my father's property in one whirlpool of destruction; and thus, through the mercy of the Almighty, was spared the misery of witnessing or sharing the fallen estate and almost utter destitution of her family.

I shall now proceed to give a short account of the education, if it deserve the name, that in my boyhood I received, as that generally, if not necessarily, follows the birth and parentage of any one who is desirous of inviting the public attention. It must have been very early in my life when I was placed in a small village school at Sutton Veyney, about three miles from Warminster, in Wiltshire; and I could not have stayed there long, as I have but an indistinct recollection of it, except upon one occasion-a visit of my father to the school, when my master, with his hand upon my head, addressing him, said, "This will make a sprask boy, sir!"

I did not then know what this provincialism was intended to convey, any more than I did the cause of my removal; but soon after $I$. found myself at a large school at Twyford, near Winchester, the same village in which Alexander Pope first received the rudiments of those classical acquirements that enabled him to astonish the world with the productions of his immortal pen.

I cannot define the period of my sojourn at this romantic little village, with the silver Itchen washing its 
flowery meads, upon whose banks we frequently met the Winchester College boys, as they were termed, and were as frequently warned by our ushers of the impropriety of provoking a collision with them; neither can I state what progress I made in those studies that are intended to prepare the mind for something more extensive than the mere knowledge of reading, writing, and arithmetic; but I can recollect nothing to justify the favourable opinion of my capacity which I foolishly fancied my first master had implied. In after-life I met with many of my then school-fellows, who had attained to decent positions; and one or two in particular, who had risen to respectable rank in the army.

I was next removed to a school on the skirts of the market-town of Petersfield, in Hampshire, which I believe availed me but little. I stopped here a twelvemonth; and my master, as I thought, was more fond of surveying the beauties of nature, which here abound, than drilling into obtuse Hampshire boys the mysteries of syntax and prosody. But if I did not advance in knowledge of the classics, I learned, either from him or through the innate love of nature I possessed, how to appreciate the beauties of that salubrious valley, which, surrounded on all sides by what appears to be stupendous hills, seems marked out by nature for the enjoyment of ease and retirement. Often, from the top of Sheet or Ram's Hill, would I stop to observe the fantastic forms the South Downs take on their lange towards the east, wondering whether the great Cæsar passed with his legions through any part of this district, on his march in pursuit of the flying Britons; next looked with that delight brilliant objects always 
inspire on the glittering little lake at their base-saw the white, chalky road winding through the hills in an opposite direction, skirting the little village of Buriton, where is now standing the house in which the historian Gibbon commenced his immortal work; then, crossing the brook, I have walked through the village of Steep, to admire the overhanging woods and deep ravines of Stonor Hill, from whose top, as from a precipice, may be seen one of the finest landscapes this or any other county can afford.

My father, then growing in wealth and prosperity, perceiving, perhaps, that I did not make the progress he had been led to expect, about this time fell in by accident with a reverend divine, who, whaterer might have been his doctrine, knew well how to practise good living; and to his care, in a convivial hour, was entrusted my future education.

This Doctor-for he was a D.D. - was eminent as a preacher, though I do not know that he held any benefice, and kept an academy in some repute at Fulham. He, I have heard say, was a well-disposed man, of good average acquirements, and with a fair share of colloquial as well as pulpit oratory, which he was fond of displaying to those whom he honoured with his company, and who might benefit by his homilies-but they were not his scholars; he left them generally to the care of his ushers; and never shall I forget the torments I suffered from the punishment the senior pedagogue from some particular dislike, or from the love of inflicting pain, thought proper frequently to visit me with-unknown, I was sure, to his principal. 
However, in the course of the first twelve months of my stay, the principal died, and the scholars were sent home, some of them never to return. This was not my case; at the request of the widow I was allowed to remain, and after a little time the school was conducted by a gentleman who had graduated at Oxford. Then, indeed, did a revolution take place in that afterwards most excellent school-and then did my young mind first begin to find pleasure in learning. The petty tyrant who had exercised such arbitrary and cruel rule, always carrying in his pocket a peculiar instrument of punishment of his own invention, with which he struck terror and hatred into the hearts of most of the scholarsto my great relief and joy was sent away. No usher was allowed to strike a boy under any circumstances. Chastisement was administered by the master's hand alone, and so superior was the system this excellent man judiciously adopted, that the cries of a delinquent were seldom heard. By his easy and temperate nethod, learning was made attractive to even the unwilling mind. The most sullen temper was subdued by his kind and persuasive manner. He was at once a well-bred gentleman, an accomplished scholar, and a sincere Christian, and possessed by nature the power of drawing and attaching to him the affection as well as the obedience and esteem of his pupils. Naturally of an inquisitive disposition, I was led by this good man to drink at the fountain of knowledge. It is true I could sip but little, and but little I may have retained, through a long and fitful existence; but young though I was, I can well remember he was the first to pour into my heart, from 
the stream of ancient lore, the sweet, refreshing drops of an intellectual nectar. To him I am indebted for imbibing a just appreciation of the value of the learning, which harsh and untoward circumstances gave subsequently to the winds. I need only add that during the four years I was at his academy I may truly point to the last two as being the most happy of my life. But this was not to last. At the commencement of the summer vacation, in the year 1806, I took my leave of this worthy person, little thinking that I should never again touch the hand of one who had directed and encouraged my studious disposition, and so kindly applauded my assiduity, and expressed his gratification at the progress I had made-little supposing I should never look upon those mild, intelligent features againbut so it was. I remember to have heard from a near relative of his, for whom I formed a sincere friendship some few years afterwards, of his early death. The intelligence caused me to recall to mind his many virtues and commanding talents, and ever since to cherish for them the greatest respect.

My trunk having been sent by the carrier overnight to the office in London, I walked, in company with one of the ushers, over Putney Bridge, and awaited on Wimbledon Common the coming by of the coach that was to convey me to my father's dwelling, not dreaming of the sudden turn my fortune or destiny was about to take.

I have been on many roads in almost every part of England, and in none have I ever witnessed finer scenery than the ride from London to Portsmouth afforded. To be seen to perfection, it must be on a fine day from the 
top of a stage-coach. Haldown on the road from Exeter to Plymouth may rival it in extent, and Moranscourt Hill on that to Hastings in richness and splendour, . but neither of those lengthened rides can come up to it in that diversified and real picturesque beaty to which my pen must fail to do justice. The vehicle I mounted was not of the most elegant build, and was certainly capable of those great improvements that were so freely bestowed on such carriages before they were quite sent off the road; neither was the pace anything like what was afterwards reached-thirteen or fourteen hours accomplishing the seventy-two miles, subsequently done in seven or eight; still it was considered a great accommodation and a good equipment in those days. The coachman, by whose side I sat, had particular charge concerning me, and was pleased to point out the objects most worthy of notice.

Crossing the Common, where was exposed to view on a gibbet the remains of a celebrated highwayman, called Jerry Abbershaw, at whose dangling chains and halfdecayed bones in our holiday walks I had cast many a stone, we ascended Kingston Hill, leaving Coombe Wood, the seat of Lord Hawkesbury, afterwards the Earl of Liverpool, on the left, and Richmond Park on the right, from whence you have a wide extent of prospectthe Thames winding its majestic course to the great metropolis from the foot of an eminence, where stands the lofty towers of Windsor Castle (the residence of our sovereigns for centuries), first washing with its yet unpolluted waters the villas of Pope and Horace Walpole.

Passing through the old and ill-paved town of 



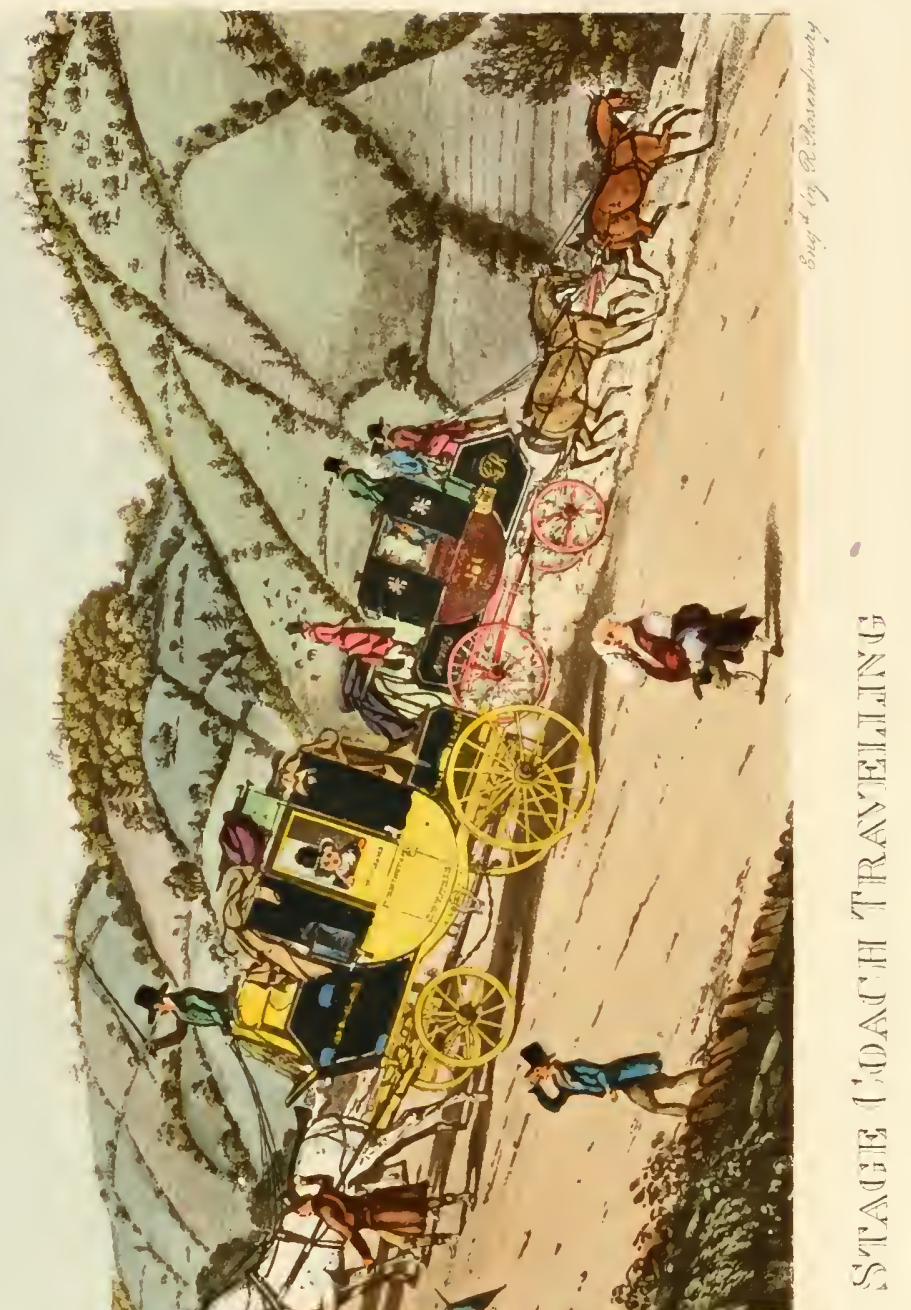


Kingston, where rests the rude stone on which the Saxon monarch sat at his coronation, ${ }^{1}$ on the opposite side of the river stands the stately edifice of Hampton Court Palace, with its parterres, its labyrinths, and its well-trained vines. Crossing a flat, called Ditton Marsh, at Esher, on the left the fine Grecian structure of Claremont meets the eye, then the property of Mr. Ellis, afterwards Lord Seaford; since the scene of the premature death of the lamented Princess Charlotte of Wales, and now the residence of Amelie, late Queen of the French.

Proceeding through the post-town of Cobham, you sec Paine's Hill, once the seat of Colonel Luttrel, often mentioned by the celebrated Junius, but then the property of a member of the same family-the Earl of Carhampton. Onward, through Ripley, you pass the parks of Lords King (now Earl Lovelace), and Onslow, the one on the left, the other on the right, till you come to the county town of Guildford, from whence, right and left, you have delightful views of the neighbouring Surrey hills.

Crossing the Wye, and passing through Godalming, with the woody heights of Busbridge on the left-then the seat of Mr. Hare Townsend, the friend and companion of the great Charles Fox-the road opens on a wide, extensive heath, with a continuous rise. Leaving Pepper Harrow, the seat of Lord Middleton, on the right, it

1 This remarkable relic has of late been surrounded by an iron palisade, the better to preserve to remote posterity so singular a memorial of the rude simplicity of our Saxon ancestors. It may be said to represent the lasting solidity of a constitutional monarchy, of which it is aptly the foundation-stone. 
winds round a deep dell, known as the Devil's Punch Bowl, till it reaches the summit, called the Hind's Head: on the top of which stood another of those "hanging woods" frequent in the latter part of the eighteenth century, and not totally lost sight of till long after the commencement of the nineteenth-this was a tripartite erection-and the names of the parties and their crime are recorded on a stone still standing by the side of the bowl, down which they dragged their victim. Looking down the deep declivity that forms the side of this spacious circular ravine, here and there you might see peasant boys gathering berries, and a very little stretch of imagination will enable you to recall a familiar paragraph from "Lear," and almost realize the picture the poet has so graphically drawn :-

"Half-way down

Hangs one that gathers samphire: dreadful trade!

Methinks he seems no bigger than his head."

Elevated about 1,000 feet above the level of the sea, you have one of the most magnificent and picturesque views the mind can contemplate from such a position. In vain the eye attempts to rest upon any particular object, except at its extreme points. On the right the hill that bounds the sight in that direction upholds the little town of Nettlebed, in Oxfordshire; while on the left the eye can distinctly perceive an object in Tunbridge Wells, at a distance of 130 miles, across steep hills and deep ravines; heath and forest, glebe and meadow, presenting a landscape that bids defiance to the art of man to describe.

I cannot refrain from recording the impression made 
on my mind by the beauty of this delightful scenery. I have since often enjoyed it, and many others must hare admired it, but it is now for ever closed to the traveller by rail.

Proceeding at a more rapid pace down the descent over what would appear, from the rich yellow flowering of the furze, then in the fulness of its bloom, to be the historical field of the cloth of gold, we reached the little hamlet of Liphook, and stopped at the "Anchor" - a well-known posting-house-half-an-hour to dine. Starting from thence, we trotted briskly on an undulating road, leaving the seat called Hollycombe, the property of Mr., now Sir C. Taylor, on the left, with sight of Woolmer Forest, the scene of White's natural history of Selbourne, on the right, and a most lovely romantic valley, bounded by lofty hills in the distance, to the town of P'etersfield, a locality I hare already mentioned ; and then, after an additional two hour's ride through and over the downs, occasionally catching a glimpse of the element that has added so much to the glory and safety of our country; we enjoyed a most splendid view from Portsdown Hill, comprising Portsmouth harbour, Spithead, and the Isle of Wight-and at last arrived safely at Portsmouth.

My father, having a very good house in the High Street, was residing there during some addition or repairs he was making at his place in the country. Something appeared to have disturbed him, for I had scarcely had time to enjoy the welcome with which I was received by other members of my family, when somewhat harshly he intimated the necessity of my preparing at once to do TOL. I. 
something in the way of earning my own subsistence; and stated that he had already made arrangements for my quitting home with this object. At this unexpected announcement I burst into tears, and implored him to revoke his decision. A captain in the Proyal Navy called in, and after the customary salutation, seeing my distress, said, in a bluff manner,-

"What's the matter with the lad?" Having been informed of the cause of my grief-for grief it really was -addressing me, he asked, "Will you go to sea with me, my boy?"

Dashing the tear's from my eyes, I replied, in an audible voice, "Yes, sir."

Without further consideration or consultation, the affair was arranged. This was on Wednesday evening. On Sunday morning following I was outside the Isle of Wight, steering down Channel with a flowing sheet.

And thus, gentle reader, ended my education, in the common acceptation of that term. 


\section{CHAPTER II}

THE VOYAGE OUT

The Departure and Outfit-A Fourth-rate Man-of-War-Captain, Officers, and Crew-Sea-sickness-The Quarter-deck-The Cock-pit-An Accident-Lubbers' Hole-The SchoolmasterMidshipmen-Rio de Janeiro-An Extraordinary Feat_A False Alarm-The Captain's Table-A Court-martial, Sentence, and Execution-Scenes in the Gun-room and in the Captain's Cabin -A Pleasant Time-The Middle Watch-Fore and Afternoon Watches-The First Lieutenant-Corporal Punishment-The Haven.

THE bustle of preparation consequent upon a sudden and hasty departure on a voyage of uncertain duration, causes such a degree of excitement among all the members of a family, both young and old, as to divert their thoughts from dwelling on the dreaded "farewell," and serves to shield the heart from the effects of the sorrowful anticipation of a long separation.

The determination thus taken was without reference to the fitness of my capacity, either of mind or body, for such a profession, or to the future fate of a boy twelve years and a half old. The ship being under sailing orders, I was soon attired in the uniform of a midshipman of the Royal Navy, with a cocked-hat on my head and a dirk by my side, and was not a little proud of my appearance. In the meantime, my kind parents were busily employed in purchasing my outfit, in providing me every- 
thing I did want, and many things I did not want, that afterwards conduced to the especial sport and jests of my messmates.

The ship I went on board, after taking leave of my friends, was one of the worst class of two-deckers-high out of the water, short, wall-sided, with a bluff bow and a square stern. She was the last ship built of that class, and had been recently launched from Portsmouth dockyard. The improrement in our naval architecture may date from this time, when the superior models of the French and Spanish ships, taken during the late war, invited the attention of the Admiralty or Nary Board to their particular structure, and soon condemned such vessels as I have named to serve as hospital or convictships.

On board of a man-of-war, then, of the fourth class, I was admitted as a supernumerary midshipman, under the especial charge of the captain, who bore the family name of, and was closely connected with, an Irish earldom. ${ }^{1}$ The ward-room officers consisted of four lieutenants, a master, a doctor, a purser, and two marine officers. The cockpit contained, with midshipmen, master's mates, doctor's mates, and captain's clerk, in all about twenty, while the crew consisted of about five hundred, including warrant, petty officers and idlers, most of them first-class seamen, having been pressed from a homeward-bound East India fleet in the Downs; and no finer crew ever went to sea in a British man-of-war.

Our captain's order's were to take charge of a fleet of Indiamen, South-Seamen, \&c., that had assembled at the

1 Thomas Gordcn Caulfield. 
Motherbank, and convoy them to their destination, which was principally Calcutta.

Being thought too young to join either the starboard or larboard mess in the cockpit, I, with two other youngsters, as we were termed, were committed to the care of the gunner-a hard-featured, weather-beaten Scotchman, though rough, yet kind in his manner.

No sooner was the anchor weighed and the ship under easy sail, than I was seized with a nausea that soon extinguished all feelings of regret at leaving my homeindeed, almost all remembrance of that home and its inmates. I suffered from that dreadful sea-sickness three days, refusing all sustenance, till, on my partial recovery, the gunner gave me a cup of strong tea without either sugar or milk. I drank it, but I cannot recall what effect it had towards my restoration; nevertheless so did I loathe his remedy, that I have never since touched, nor could I ever be persuaded again to taste, that highly-prized beverage, though more than half a century has clapsed-such is the force of early impression, combined perhaps with prejudice.

Had I any particular emotion either of diffidence, or gratification, or pride, on my first coming on deck and viewing the wide expanse of waters, covered as it was by innumerable ressels spreading their white canvas to the wind, they were soon dissipated by the strict order that was kept on one side of the quarter-deck, and by the jocose observations, some of kindness, some of scorn, made by persons on the other. To aroid their not very pleasing jests $I$ ascended the poop ladder; and the captain, seeing me, gave the first-lieutenant instructions that my 
earliest duty should be to attend and assist the signal officer, who was then present arranging the different parti-coloured pieces of bunting, and immediately commenced his tuition; and I had the good fortune soon to ingratiate myself with one whom I afterwards found to be a thorough-bred gentleman, and a most excellent officer. $^{1}$

The cock-pit of a man-of-war may be justly termed the school of our naval heroes, where the peculiarities of mind and temper are sure to be dereloped. The characters and dispositions of its different inmates, their amusements and their feuds, have been so graphically described by Captain Marryat and other nautical novelists, that I can only testify to the general truth of their delineations. It was some little time before I was admitted among them, and more before I became thoroughly acquainted with the usages of so unique an assemblage as a midshipman's mess, or acquired anything like a perfect knowledge of those who composed it.

An old seventy-four, called the Russell, with an additional fleet of merchantmen, liad joined us oft' Plymouth; so that together we made a considerable flotilla, not only in numbers, but in wealth. Our sail to the island of Madeira, where we stayed but two days, was marked with only one incident worthy of recording; my time was taken up principally in assisting to make and repeat signals, to keep the convoy together, to prevent them straggling too much to windward or to leeward, and to compel the sternmost to make more sail. In the evening the crew were exercised at the guns, or sometimes

${ }^{1}$ Lieutenant Samuel Greenway. 
iu reefing topsails; and it was upon one of the last occasions, when the captain had ordered the men up aloft a second time in consequence of their not being smart enough to please him, that one of our best men fell from the main top-sail yard-arm on to the larboard gangway, and was killed on the spot. I was standing by the side of the captain on the poop at the time, and when he went down the ladder on to the quarter-deck into his cabin, his face covered with his hands, I did not envy him his feelings.

I cannot boast of any progress I made in my profession during this short rum, unless it be that I was able to reach the main or mizzen top, though not by the way used by the topmen, the futtock shrouds, but through "Lubbers" hole," as the sailors call the open space in that lofty platform.

While at Madeira our captain induced his brother of the Russell, to let us have the assistance of a schoolmaster he had on board, for a few weeks; and during the run to Rio Janeiro he assembled the midshipmen every day in his cabin to be instructed in navigation. My aptitude for learning had not forsaken me, and I quickly left my competitor's for scientific acquirements a long way behind. Geometry, Trigonometry, and Mensuration were soon mastered, so well had I been prepared at the school I had so recently and so reluctantly quitted. At the end of six weeks I was as capable of taking and working a lunar observation as any officer in the ship-much to the annoyance of many of my brother midshipmen, my seniors in age and service; and haring obtained a greater share of notice in consequence, did not add to my own 
social comfort or happiness. Nevertheless, confident, or vain, perhaps, of the superiority I had gained, I treated their jeers and their contumely with all the contempt I could assume, though I was frequently provoked to words of recrimination and abuse.

One of these, whose sponsors had thought proper to bestow on him the lofty baptismal name of Theophilus Caractacus, was a tall, gavky youth of about eighteen, who, whaterer his pretensions were to emulate the deeds of his illustrious namesake in arms, certainly bid fair to be on a level with him in his intellectual capacity-for the knowledge of letters seemed as foreign to him as they were to the ancient Briton, from whom, like other Welshmen, he boasted his descent. If, by the other appellation, it was intended that he should in his manhood bear any resemblance to a name known in the early history of our creed, his friends must have been disappointed, for meekness and charity were not to be reckoned among his rirtues. This man or youth was my particular bane, and fortunate was it for me, perhaps, that I did not belong to the same mess, for, although the disproportion of our physical powers precluded, for shame's sake and the fear of others more his equals, the probability of any personal encounter, still, when assembled on the poop or quarter-deck to take an altitude at noon, his renom would display itself in some arrogant expressions on the inequality of our births; and my angry, and sometimes pithy, allusions to his gross ignorance would excite general sympathy, while some happy travesty on his high-sounding name would create the laughter of our superior officers. 
Another, with whom I was more immediately associated, for he was one of the three committed to the care of the gunner, was a true scion of the aristocracy, had some pretensions to the birth of a gentleman, and would be possessed, on coming of age, of considerable property. This hero in embryo would take frequent opportunities of showing his personal dislike, as well as his contempt, for all beneath him in birth and connections. He was my superior in age by two or three years, and I should have fared badly with this haughty, supercilious boy, as he then was, had it not been for the fellow-feeling, that afterwards ripened into a brotherly friendship, existing between myself and the third individual, who with us constituted our little mess; and the severe remonstrance sometimes administered by our kind-hearted president, who himself had no particular regard or respect for youths of aristocratic bearing.

This promising young officer, on the arrival of the ship at Madras, told the captain the service was not fit for a gentleman, and begred to be invalided home; this was immediately granted. He quitted the ship unregretted by either officer's or crew, and I have never seen him from that time. I believe he afterwards entered the army, which he left on some similar pretence; his name was well known in the fashionable circles for some few years, and was mentioned in connection with the celebrated ball at Brussels, prior to the battle of Waterloo, where the charms of Lady Frances Wedderburn Webster attracted. the attention of the hero of that eventful day.

The third of my associates was a fine, handsome lad, a little above my own age, fresh from the sister isle, of 
primitive ideas, but of a noble and generous nature. He was also a protégé of the captain's, and was extremely well connected. I remember it was a standing joke against him, which he always took with habitual goodhumour, that one day at the captain's table he attempted to invert the process of eating asparagus, by squeezing the palatable part between his fingers, and putting the less succulent end to his lips; the loud laughter of the captain's guests soon corrected the mistake.

Nevertheless, his simple and unsophisticated manner gained him friends; and, had his life been spared, he would have been a star in the firmanent of the profession, which he followed with much ardour and devotion. $\mathrm{He}$ was sent away in a boat with two others, under the command of a lieutenant and boatswain, to cut out and destroy some Malay praams that had taken shelter under the high land on the coast of Sumatra. The lieutenant was the first to climb the bors of the pirate; my poor friend followed him, when the foremost Malay made a thrust with his spear, which passing through the lieutenant's trousers, entered the chest of this brave youth, and caused him to fall backwards ; the boatswain, whose name I remember was Thomas George, a fine athletic fellow, mounting the deck at the moment, with his cutlass serered the fellow's head from his body. The rascals soon ran below; and on battening down the hatches to secure them and mustering the crew, only one was missing, and that was my most esteemed friend.

It was supposed that from the force of the spear alone he must have fallen between the praam and the gunwale of his own boat, and, from his body not being found, have 
met a watery grave. His loss was sincerely lamented by captain, officers, and crew. I was not a spectator of this sharp and successful encounter; but it was as the lieutenant in command related it to me. At parting, I had exchanged seals with this amiable youth, and in doing so we both fondly anticipated some future happy meeting, but that was not to be in this world. ${ }^{1}$

But this is anticipating my story. On casting anchor in the harbour of Rio de Janeiro-then the principal trading port in the Brazils, and subject to the Crown of Portugal, now the capital of an extensive and rising empire-we found three line-of-battle-ships and a frigate, with the flag of Admiral Hartsinck, belonging to the Batavian Republic, who had, at the bidding of the French Government, recently declared war against us. About three days after our arrival we were joined by two new seventy-fours, the Allion and the Sceptre from England, sent out to reinforce the squadron in the East Indies, under Admiral Rainier. This was considered a very timely arrival for us, as, unless we had been reinforced, we must have remained there-for, although three days must elapse between the sailing of two hostile fleets from a neutral port, we could not have left without the certainty of being overtaken by the enemy, as several of our convoy were very dull sailers. As it was, we now considered ourselves quite a match for them, and, should

${ }^{1}$ He was Luke Burgh.-Some few years afterwards I read with much gratification the advancement of a military officer of the same name, Sir Ulysses Burgh, whom I took to be his elder brother, to the peerage of the United Kingdom, by the title of Lord Downes. He had served on the staff of the great Duke throughout his campaigns in the Peninsula. 
they dare to pursue us, had made up our minds to give them a warm reception. Nevertheless, while we were lying there together, every civility passed between the senior officers of the two hostile fleets. Independent of balls, and fêtes, and dinners on shore, given by the Portuguese authorities, in which no preference was shown to either nation, a reciprocity of visits daily took place on board one or other of the men-of-war, each taking it by turn to entertain the officers of the other; while the midshipmen would endeavour to surpass each other in feats of daring agility on the masts, yards, and rigging of their respective ships. Hence the foundation, if not the truth, of that feat of our countryman that has since obtained general circulation, but is set down by people on shore as nothing better than a Joe Miller or a Munchausen.

The Dutch, whatever may be the distinguishing features of their more mature age, are in their youth and on the water particularly bold and active. Upon the occasion I am now relating, one of the Dutch midshipmen ascended to the main-royal mast-head and sat at his ease on the truck, which in shape and size resembles a small round table, and between it and the sky there is nothing. One of ours, on seeing this, immediately ran up the rigging, and with great apparent ease and confidence, stood upon the truck, and waved his hat in defiance. This was not to be borne, for the Dutch boy, with wonderful daring and activity, turned himself over, and stood upon his head, with his heels towards the heavens, to the amazement of the crews of the other ships, both English and Dutch. Determined not to be outdone, with more spirit 
than discretion, the British youth attempted the same exhibition, but not being so clever at gymnastics as his rival, he toppled over and fell, to the great momentary alarm of his shipmates; but first a stay, then a backstay or bowline, breaking his fall, he came safe on deck; when, jumping up and snapping his fingers at the Dutch line-ofbattle-ship, with great presence of mind, he said, "There, gentlemen, do that if you can!" The ship was not within hearing, nor could the crew have understood our language, but the loud shouts of laughter and exultation this feat elicited from both officers and men announced to their astonished minds that an Englishman was not to be beaten at that or any other game.

After three weeks' stay at this hospitable port, during which time we were employed in refitting our rigging and replenishing the water-casks, we set sail some time in September-the other three men-of-war and convoy in company-for our ultimate destination.

We had not much expectation of Admiral Hartsinck's following us, though we always kept a sharp look-out night and day, but we saw nothing of him or his squadron. We were stationed in the rear of the convoy, to give timely notice of the approach of an enemy, as well as to whip up and cover the stragglers; when one night, observing what we took to be a large ship on our larboard quarter, and not being able to make her out, we piped all hands to quarters, and cleared ship for action. The captain and officers on the deck were intent on observing her with their night-glasses. The lower deck guns were run out, and we every minute expected a broadside, and were prepared to return it. To our great surprise and 
disappointment, upon a closer inspection she turned out to be one of our own convoy, that had got out of the order of sailing, and had straggled away from the rest of the fleet; and not understanding our night signals or not answering them, she had caused us to mistake her for an enemy.

About a week after we had left Rio, thinking there was no chance of the Dutch squadron molesting us, the Allion and Sceptive made signal to part company, and, crowding all sail, were hull down at sunset, and next morning were nowhere to be seen.

I must here relate a circumstance of not very frequent occurrence in those days in a man-of-war, when long voyages were unavoidable, and the captain's power unlimited, but is now, I beliere, out of the scale of probability; it was one, too, that materially altered my position. Two of our midshipmen were not on very good terms with the captain. One had refused his invitation to breakfast, which being reported to the captain, and, as I understood, his refusal or excuse being highly coloured by the valet or steward (who to the best of my recollection was either Swiss or French), his commander said that he never knew a midshipman in his life but what would eat tuo breakfasts; consequently he fell into disfavour: the other had been so for some time. It was the custom of the service then, and I believe it is so still, for one of the midshipmen to breakfast and another to dine with the captain every day; they were selected in turn, the first from the morning, the other from the forenoon watch.

In consequence of the expected long run to Calcutta, 
that the dull sailing of the convoy had caused to be of unusual duration, and there being no port at which we could possibly touch before reaching the Bay of Bengalthe Cape of Good Hope being at that time in the hands of the Dutch, it having been restored to them at the peace of Amiens - it was thought necessary to put the ship's company, officers included (for there is no distinction in these cases), on a short allowance of water.

Now it came to the turn of a young Irishman, who had served about lalf his time, by the name of Nixon, to dine with the captain, a day or two after; and in the course of conversation at the table he was asked how the young gentlemen, meaning the midshipmen's mess, did with the minimum of water to which they were restricted. In the simple and ingenuous manner that was natural to him, he replied, "Oh, capital! very wellindeed, they could do with half the quantity." Whether the captain took him at his word and acted accordingly, I cannot at this distance of time pretend to say, but on his retiring from the table and coming below, his messmates flocked round him, requesting to know, as was usual with them, what the captain talked about; when he repeated the conversation, and foolishly divulged the error he had committed.

Upon this the majority of the mess took umbrage, and accused him of being the cause, from his folly or obsequiousness, in attempting thus to gain favour with the captain, of the privations they were about to suffer for the remainder of the voyage; and upon one or two of them saying he ought to have a good licking, it was quickly resolved, at the instigation of the doctor's 
mate, that he should be tried by a court-martial of six of the elders of the mess, the senior master's mate to be the president.

This mock trial was soon over; he being convicted by his own confession, there was no necessity for any further evidence; and the president, after a short consultation, sentenced him, in nautical language, to be cobbed-a punishment, I believe, only known on board ship. Resistance was useless, and he was immediately seized up to the aftermost gun on the lower deck; the captain having given the gun-room to the midshipmen for their better accommodation, it being more freely ventilated than the cock-pit, consequently more healthy, particularly in a tropical climate.

By the artful advice of the doctor's mate, who was no friend to the youth, and owed him a grudge, everyone in the two messes was included in the infliction of this punishment, on the pain of being served the same, or sent to Coventry.

The instrument selected for the purpose was what is called by the ship's cook the "Burgoo-stirrer" " in shape it resembles a large battledore, and is generally made of some hard wood. With this formidable weapon each one was to give the culprit six blows upon the most fleshy part of his body-which, though not uncovered, presented, from the attitude to which he was confined, an unmistakable mark.

'The master's mate-a fine young man, about nineteen or twenty years of age, and nearly six feet high, ${ }^{1}$ and

1 This young man in time rose to the rank of Post-Captain, Sir John Marshall, and was a Knight Commander of the Bath at his decease. 
who had acted as president, was the first to put the sentence in force; and the victim writhed and twisted under his powerful blows, though his proud heart would not suffer his lips to utter a word of complaint. Two or' three others followed, when, either from compassion or want of muscular power, they did not draw forth from the sufferer any particular signs of anguish; but when the doctor's mate, a tall, raw-boned, long-armed Scotchman, took the implement of torture, and administered his blows, with all the strength a sinewy arm and malignant spirit could give, the poor youth, no longer able to contain himself, absolutely roared with pain. The punishment over, the prisoner was cast off, when he immediately ascended to the captain's cabin.

I was a silent spectator of this specimen of Lynch law, as it may be termed, and was not thought of importance enough to be included in the unanimity with which the whole proceeding was conducted; but I looked with something between compassion for the delinquent and anger and horror at the two principal perpetrators in this, to me, diabolical affair, and marked the fearful silence that reigned among them, till they were one and all summoned to the captain's presence.

I followed, as did my two young messmates, who had been for the same reason excluded with myself from any participation in the crime or folly of the others. Those, also, who fortunately had the watch on deck at the time of this unjust assumption of authority and act of downright eruelty, were also called in.

The first lieutenant stood by the side of the captain, as did the doctor and purser; the master, and most of FOL. I. 
the other officer's, were also in the cabin, when their commander expressed himself in an angry tone, and in the strongest terms of reprobation at their recent conduct; condemning it as unworthy the character of gentlemen's sons, at variance with the rules of the service, and totally subversive of that good feeling that should actuate young men who were desirous of advancing in the profession; and on that account, if on no other, should cultivate each other's friendship and good-will.

For this grave offence, which he told them he could not stigmatize too strongly, he said that he should from that hour disrate all who had been guilty of such a disgraceful conspiracy; and that upon his arrival in India on the station he should apply to the Admiral for a court-martial of a little different nature from that they had concocted, when they would most assuredly be dismissed the service. In the meantime, they were not to do duty any more as officers on board his ship, nor were they to appear on the quarter-deck. This sentence, howerer serere it may be thought, was put in force immediately by the captain calling in his clerk, who in their presence erased their names from the list of petty officers in the ship's books, reducing them to the rank of A.B. or O.S., in which capacity some of them were compelled to do duty; one of them, I remember, who had in the early part of the voyage fallen under the captain's displeasure, was put in the foretop.

This was the unfortunate youth who could not eat two breakfasts. "Henry Parry," bawled out the first lieu- 
tenant, "you will do duty in the foretop starboard watch; and if you don't answer to your muster, I'll start you as I would any foremast man."

"Hard cheese for a gentleman's son," said one or two of his messmates; but he submitted, and did his duty so well, that one evening, when reefing topsails, the captain observing him said, addressing the first lieutenant, Graves,-

"Who is that smart lad on the foretopsail yard-arm, at the starboard ear-ring?"

"That's Parry, sir."

"Call him down," said the captain, then first relenting, "and send him aft."

This gentleman is now on the reserved list of commanders, and the author has had an opportunity of renewing his acquaintance, after an interval of more than forty years.

This done, they left the cabin, when the captain, turning to the sufferer, who stood with tears in his eyes, rubbing the part which had been the seat of so much pain, admonished him, in very strong terms, on the impropriety of his conduct, in repeating or divulging anything he might have heard at his table. He then addressed us youngsters, and warned us never to be guilty of the same thing; so saying, he waved his hand, when we bowed and left the cabin.

And'never have I forgotten the lesson thus early implanted in my mind, which is applicable to all stations and ages; for mischief, even to death, has been caused by words being incautiously repeated. The whole scene, from the beginning to end, made such 
an impression on me, that it is as fresh in my memory as if it had happened but yesterday.

A fatal instance of imprudence occurred on the West India station, a few years after I left the service; and although I believe it has been recorded by one or more of our nautical novelists, it may not be considered out of course repeated here, as it was related to me by an old shipmate of mine, who was, I believe, an eyewitness, not many months after it happened-I allude to a duel that took place between Captain Stackpole of the Statira frigate, and a lieutenant of another of H.M. ships on the same station, named Cecil. The captain was considered a dead shot, having sailed as a lieutenant with that celebrated duellist, Captain Macnamara, who, it may be remembered by some of the oldest of my readers, killed Colonel Montgomery; and though himself wounded, was tried with his second at the Old Bailey for that affair.

It was their custom, when at sea, to practise pistolshooting, by putting a solitary fowl in a hen-coop, placed prominently before the others on the sparsthat is, between the main and foremasts; a little barley would be strewed in the trough, and when the bird put its head out to feed, it presented a fair mark to the two officers who stood on the poop, when one or the other seldom missed; and this was repeated till a sufficient number had been killed to supply the captain's and ward-room officers' tables. By this method they became experienced and excellent marksmen.

The captain had heard from some officious talebearer that a young and excellent officer had said, when 
speaking of him (Captain S.), that he was a good fellow enough, but that he could pull the long bow; which the generality of my readers will at once understand means that he could exaggerate, and perhaps a little more. This, it seems, the captain cherished in his memory. One day, being at anchor in PortRoyal, Jamaica, a man-of-war was seen steering for the harbour, and upon her number being made known, he recognized the ship of which his intended victim was first-lieutenant. He immediately sent a note on board, stating the nature of the offence and demanding a written apology or a meeting. The lieutenant, who bore an excellent character as an officer and a gentleman, returned for answer that he had no recollection of having used the words imputed to him; but if he had incautiously done so, he was ready to make a verbal apology.

This did not satisfy the captain, who would have nothing short of a written apology; this again the lieutenant absolutely refused, saying, to any other man but Captain S. he would readily subscribe to the terms proposed, but to him never, as, from his well-known practice, his doing so would be attributed to cowardice, and for ever ruin him in the service.

Accordingly a meeting was appointed. In going to the ground, Captain S. met his adversary's captain; he stopped, and in the most confident manner said, "I am compelled to deprive you of the services of your firstlieutenant for a short time-I shall only wing him;" and then walked on to the spot, where he found the lieutenant waiting with his friend. The ground was 
measured, the pistols delivered by the seconds, and each took his position. So unacquainted was the lieutenant with the nature of this detestable practice of settling disputes, that he presented his front to his adversary, which the captain observing, said in a low voice, "Show me your feather edge, sir, or I'll shoot you as dead as a rat." Upon this, by direction of his second, he adjusted his position, and on the signal being given they both fired. The lieutenant stood unhurt; while the captain fell, exclaiming something expressive of his surprise at having missed him, and died before he was carried off the ground.

The words which the great Napoleon said, when General Moreau was mortally wounded by a cannon-ball before the walls of Dresden, "Surely the finger of l'rovidence was there," may much more justly be applied on this occasion. The body of Captain S. was interred in the burying-ground at Port-Royal, and in one short year after, his adversary lay by his side, having died of yellow fever.

The day after our assembly in the captain's cabin the order of the watch was rearranged, and we three, who were now raised from supernumeraries to the rank of full midshipmen, were, with the junior master's mate (who, wise in his generation, had either cunningly or accidentally avoided committing himself as the others had done), were put into the third lieutenant's watch, the officer who from the beginning had taken me under his kind protection. Then did my time pass pleasantly enough; feeling a little my importance, as forecastle 
midshipman, I thought I was gaining ground on the great Caractacus, who had but so recently occupied that post, and who was now debarred, with the others who had been disiated, from speaking to us, either off or on duty. Added to the satisfaction of being out of reach of such annoyance, the haughty demeanour of the other individual I have before alluded to was somewhat softened down towards me, if not totally changed, by the tact and impartial conduct of the officer of our watch, who would see no difference, and make no distinction between us, and did all he could to make our duties light and our time happy.

Often in the middle watch, when crossing the South Atlantic, with the trade wind blowing steadily and constantly from one point of the compass, little or no alteration in the trim of the sails or quantity of canvas was necessary, under a sky sparkling with a brilliancy unknown in the northern hemisphere, and nothing was heard but the reply of the man at the helm to the quartermaster. This officer would assemble us on the poop, and, sending to his cabin for a liquor-case, he would invite us all to fill our glasses, and then cause each of us to sing a song, himself joining in the chorus; sometimes varying the amusement by exercising his wit good-humouredly on my Hibernian friend; at others with anecdotes gained from his own experience in the service, or by some happy allusion to those we had left behind.

The greater part of the morning watch in those warm latitudes and comparatively smooth seas I spent in climbing the masts and rigging; and I had now gained sufficient 
courage and confidence to reach the truck, but not to rival the feats of either the Dutch or the English midshipman.

In the fore and afternoon-that is, when it was my watch upon deck-I would employ myself in learning to knot and splice, under the tuition of the captain of the forecastle-a fine specimen of a British sailor; and frequently learn from the boatswain, who took pleasure in instructing me, the names and use of the different ropes, the marks on the lead line, and every part of practical seamanship. Indeed, with the crew generally I was an especial favourite, who, with but one or two exceptions, were quiet and orderly men, of sober and obedient liabits, and, with every characteristic of British sailors, united a respect for, and attachment to, their officer's.

The first-lieutenant, who, under the captain, is the principal agent for creating and maintaining a proper discipline in the ship, was a man somewhere about thirty years of age, not tall, but very stout, of a fine open countenance, and with lungs that did not require a speaking-trumpet to make his voice heard either aloft or on board any strange ship we had occasion to hail. He was every inch a sailor ; and, from the straightforward, officerlike, and impartial manner in which he carried on the duties in all the various departments of the ship, had obtained among the men the soulriquet of "Honest Joe," though that was not his baptismal name; and to his thorough knowledge of the service, as well as to his proper way of treating men who were their country's boast, may be attributed the infrequency of corporal 
punishment among them. I remember but one instance of it occurring during our voyage out from Rio Janeiro, and that was under peculiar circumstances.

One of the boatswain's mates, who had recently been promoted to that office, was a man of arrogant deportment, and too fond of exercising his authority over men his equals in everything but rank. Upon one occasion he called one of the men on the forecastle a lazy lubber, and other opprobrious epithets, and threatened to start him; whereupon the man, not being able to keep his temper, struck him with his fist, and knocked him down.

Now, to strike your superior officer is death by the articles of war, which the captain took care to have read every Sunday on the quarter-deck. Upon this affair being reported, the man was immediately put in irons; and the next day at noon all hands were piped for punishment and the offender was brought to the gangway by the master-at-arms. He was ordered to strip, which he did without a word, and was seized up; when the captain, who was not by any means a Tartar, animadverted strongly on the offence that he had committed, by which he had subjected himself to the greatest penalty known to martial law; but in consequence of the character he bore, he had commuted his punishment, and therefore ordered him to receive two dozen lashes, for, he added, he should not be doing his duty were he to pass over such a breach of discipline.

He, who was as good a seaman as any in the ship, receired the amount of his sentence without flinching, and without a word being spoken by any of the officers, who one and all deeply sympathized with the sufferer, 
while a tear was seen to trickle down the cheek of honest old Joe.

Upon the man's being cast off, the captain addressed the boatswain's mate, and told him that he had been the means of one of the best men in the ship being flogged; that, as he found him not fit to be trusted with authority, he should incapacitate him from committing the same thing again, by disrating him from the office he then held; and he was disrated accordingly, much to the satisfaction of both officers and men.

This, I believe, was the only instance of corporal punishment we had in our long run out-a system of punishment that never should be resorted to hardly under any circumstances, as a too frequent application of it tends to debase the minds of the men, and render them callous to every sentiment of pride in their calling, or regard for their country, while it renders the officers familiar with acts that are degrading to humanity. Much to the credit of our naval discipline, it is now but little practised.

After a voyage of more than eight months at sea, except the three weeks we were at Rio Janeiro, we cast anchor in the Hooghley, in the month of February, 1804, first having made Dondra Head, where the Russell parted company with the Madras division of the convoy. 


\title{
CHAPTER III
}

\author{
THE VOYAGE HOME
}

Day-Dreams-The Shark and the Dolphin-Yarns-A Hard HitThe Armourer's Chest-Calcutta-The Marquis Wellesley-The Return-Madras-A Scene in the Water-Trincomalee and Colombo-Bombay and Elephanta-The Straits of Sumatra, and the Captain's Adrice-China Seas-A Typhoon-CantonA Distinguished Naval Officer-Parting-An Historical Comparison-An Agreeable Shipmate-St. Helena-The Chops of the Channel-The Pilot Boat-A Polite Request-The Landing -Sentiment.

During this long voyage, unequalled, perhaps, in its duration since, my thoughts often rererted to my happy schooldays; and though with something of a latent, lingering desire for their return, I cannot say the comparison was detrimental to the position I then occupied. I had already imbibed a love for the profession, though the little I had seen was of a very monotonous nature; but I felt pleased with the prospect it held out of acquiring knowledge, if not distinction. My young ideas began to expand, and I contemplated the wonders of creation in the vast extent of waters, and in the magnificent brilliancy of the heavens, with an ardent imagination.

At one time I would lean over the taffrail, and gaze on the untiring, though almost imperceptible, motion of an immense shark, who followed in the wake of our ship for 
several days and nights, as if in expectation some accident might eventually reward his patience and perseverance, till at last he would become the victim of his own voracious nature, and gorge a hook baited with a large piece of salt pork, by which means his enormous bulk was soon laying its length on the quarter-deck. At another I would watch, with indescribable excitement and delight, the apparent evolutions of the dolphin, as, in pursuit of his prey, that would frequently fly over the ship, he would bare his golden back, and blow with his wide nostrils the spray from before him, till, after an unsuccessful chase, our men would find means to land him too on the quarter-deck; and then did I witness the truth of a description a noble poet, from his own observation, afterwards so beautifully drew of the death of that remarkable denizen of the ocean, and my memory has often been alive to the aptitude and nicety of the simile:-

"Parting day

Dies like the dolphin, whom each pang embues

With a new colour, as it gasps away

The last still loveliest_till 'tis gone, and all is gray."

At the captain's and ward-room officers' tables I listened with eager attention when the conversation turned on naval tactics or engagements, in which some one of them may have participated, and have often induced the men in the night watches to repeat some act of individual bravery, either before the enemy or in rescuing a shipmate from a watery grave. All these things, small as they may be reckoned, had entered into my system, and helped to elevate my mind far beyond my years and the sphere in which I was born. How 
blind are we mortals to our destiny! Who could tell that an unseen, unlooked-for agent was at work to baffle all the fond anticipations in which my boyish fancy indulged?

Though the voyage had been long, and both officers and men had suffered those privations consequent upon it, the ship was generally healthy. On the morning we dropped anchor at Kedgeree, a port on the Hooghley, where men-of-war generally refit, but which had not been visited by a two-decked ship for nearly half a century, I was doing duty as usual in the forecastle, and, in conjunction with the boatswain, seeing the men properly stowing the jib and foretop-mast staysail. The forecastlemen had laid in, the topmen had come down from furling sails, the yards were squared, the ropes were coiled, and preparations were being made to moor the ship, when a sudden fatality befell me.

Some little time after noon I found myself lying on the armourer's chest in the gun-room, and the first person that met my eyes was a marine, who acted as the purser's servant, and through whose kindness had done me the same offices. I felt as if something had happened to me, but could not tell what. I complained of thirst, when the man gave me an orange to suck. The doctor soon after came, took hold of my hand, but said nothing. He assisted me into the purser's cabin, and laid me in his cot.

It appeared to all that I had been struck down by a coup de soleil, or sunstroke, which when I was carried below was thought to be fatal, and my resuscitation did not a little surprise all hands. Without the aid of 
medicine I gradually recovered, and to all appearance was soon fit for duty, although, from the ship's being moored, only one midshipman was necessary for each watch.

In the course of two or three days the captain went up to Calcutta, having there two brothers, one a civilian, the other in the king's or company's army. It was not long before he summoned his three youngsters to attend him there. We left the ship at midnight, not without some little apprehension, as one of our boats with six men, the coxswain and the doctor's mate, the same I have before spoken of in connection with the cobbing affair, was swamped, and every one of them had perished, it was supposed, for they were never after heard of.

Passing Saugur Island, where our ear's were regaled with the yelling of tigers and the splashing of crocodiles, we arrived safely at the city of palaces, and were immediately conducted to one of them belonging to the captain's brother, who received us most hospitably, and assigned us each a bedroom, with servants to attend us.

Here we lived for about three weeks, in a most sumptuous style, attending routs and parties of the most brilliant description, and revelling in all the enjoyments of that ever gay and luxurious capital.

But the principal incident in our visit to this seat of government was our presentation, by thé captain, at the levée of the governor. At that time the Marquis Wellesley held that princely office, and administered its functions with all the pomp and magnificence of an oriental ruler; at the same time, with all the grace and dignity of an accomplished English nobleman. Conducted 
to his presence by the captain, I was struck mute with wonder at the splendid assemblage that surrounded himthe strangeness of their colour, the richness of their costume, and the sparkling brilliancy of their jewels. On our names being announced, though before abashed and diffident, and somewhat awed in his presence, I felt relieved by the mild benignity of his manner, and could but look with admiration on this specimen of true nobility. If ever envy did possess my heart it was when that illustrious impersonation of British power and rule put his hand upon the head of my Hibernian friend and messmate, saying,-

"What, is this the son of my old friend, Colonel Burgh?" and greeted him most cordially. He then expressed his pleasure at seeing us after so long a voyage, and begged we would accompany our captain to dine with him that erening. The sumptuousness of the entertainment-the quantity of gold and silver-the strange variety of the meats-the quality of the guests, and the gorgeous display that pervaded the whole scene, as it then appeared to my simple mind, far surpasses my power of description.

On the evening of our departure from this emporium of wealth and commerce, after attending another of those costly banquets, I lay down about midnight, without taking off my clothes, as the boat was to leave very early in the morning. I never knew how I reached it, for both my messmates told me it was with the greatest difficulty they awoke me; they had, indeed, almost to carry me to the waterside-this they attributed to my having indulged a little too much in the enjoyments of the table; but 
experience afterwards convinced me that it was a repetition of what befel me the morning we anchored at Kedgeree. However, I was perfectly recorered when we reached the ship; we found her ready for sea, and I returned to my duty as if nothing had happened.

Our next destination was Madras, to join the Admiral; and in our short passage to that Presidency we lost from sickness our only marine officer, the other being left behind at Portsmouth, as well as a midshipman, and the other doctor's mate, with two or three of the men, which we attributed to the effect of the climate upon a two-decked ressel.

We did not remain long at Madras, but long enough to witness an awful casualty, not of rery frequent occurrence, but one to which the seafaring life is subject, among other dangers, unknown to the drellers upon terra firma.

Whoever has been to Madras, and remained. on board a ship at anchor in the roads, must know how the waters are infested with sharks, though they are seldom seen or known to rise to the surface, unless attracted by something in the shape of prey, and are therefore aptly denominated ground sharks. It was the custom to heare a studding-sail overboard in the morning, and, by attaching it to the fore and mizen chains, make a sort of pool for the men, particularly those who could not swim, to bathe in, and so preserve them from the attacks of these voracious monster's.

One of our men, an excellent swimmer, had the temerity to venture beyond the sail, when a shark like lightning rose from the bottom and with his extended jaws 
grasped the poor fellow's abdomen. The sea was instantly reddened with his blood; the men who were within the sail by some means rescued what was left of him from his ferocious antagonist, but life, we were all assured, was gone before we got his body on board. His mutilated remains were committed to the deep the same evening, to the great grief of his shipmates.

Some of our disrated midshipmen left us here for other ships-as did the young scion of aristocracy I have before mentioned-for England.

From thence we sailed, with the Admiral and squadron, to Trincomalee, a port on the eastern side of the island of Ceylon, and which I was told was the finest harbour in the world. I found it had not been nor could it be overrated; and it presented to my view a haren possessing every advantage of security and anchorage that the most numerous fleet might require.

We were then ordered to Bombay by the Admiral, first calling at Colombo, where we took in an officer of the 19th Regiment of the Line, to do duty as marine officer; and on hearing his name I recognized an old schoolfellow from the banks of the Itchen, consequently we became on the best of terms.

Arriving at Bombay, we underwent a regular overhauling of the masts and rigging, and finding the foremast sprung two or three feet above the deck, we had to rig shears to get it out. While all hands were at work swaying up the mast, just as the heel swung clear of the deck one of the shears broke about midships, when mast, shears, and all went orer the side with a tremendous crash, but without injury to any

VOL. I. 
of the men, or, indeed, to any part of the ship or anything alongside.

During our stay at this presidency my time was principally occupied in going to and from the dockyard, in charge of one of the boats, either to discharge old stores or to receive new, as we were very short of petty officers; but I managed to obtain a day to visit the cave of Elephanta, an island situated about two hours' sail from that part of the harbour of Bombay where we lay, and where are still to be seen those gigantic monuments of a bygone age, whose history, like that of our own Stonehenge, is lost in the remoteness of antiquity.

From Bombay we were ordered to proceed with convoy to China, touching at Poulon Penang, or Prince of Wales's Island. In our passage across the Bay of Bengal and through the Straits of Sumatra I had repeated attacks of what the doctor now decided was epilepsy, and I was ordered not to go aloft in consequence.

Becoming enervated both in body and mind, the captain one day sent for me into his cabin, and, after lamenting with much feeling the malady that had rendered me incapable of doing my duty any longer, and the little chance there appeared to be of my recovery in that climate, he said he thought he was best consulting my interest and fulfilling the promise he had made my parents by advising me to return to England, where I might obtain the best medical advice, and under proper care in my native land be rescued from the effects of so distressing a disorder. He then informed me that he should, therefore, on his arrival in China, seek out some homeward-bound Indiaman with whose captain he was 
acquainted, and procure me a passage home. To this I reluctantly and of necessity assented.

Proceeding on our voyage, we were overtaken in the China seas by one of those periodical storms known by the name of a typhoon, which surpassed all I had before seen, or, indeed, have ever witnessed, at sea or on shore, in the terrific violence of its nature and the awful appearance of the elements. Deafening claps of thunder, that seemed to threaten annihilation, instantaneously followed lightning, that, in its dart-like peculiarity of form and unearthly variety of colour, together with the blackened intermission of its awfully vivid flash, seemed to display the vengeance of an offended Deity. The rain fell in such torrentsat intervals as are only known within the tropics; while the violence of the wind agitated the waves to a degree that prevented all management of the ship.

For several hours we were under bare poles; not a stitch of canvas was to be seen in any of the fleet; the hatches were closed, and nothing but a biscuit and a glass of arrack served out to the men during the continuance of the storm, which was of thirty hours' duration.

The convoy was dispersed in all directions, owing to the violence of its effect.

The Dedaigneuse, a small thirty-two-gun frigate, rolled away, her masts under our stern, and we all expected to go down every minute. We afterwards learned she was saved only by the coolness and courage or superior seamanship of her commander-by his experience and knowledge of the proper resources in such 
an extremity. Our own ship rolled and pitched so unmercifully, from the short chopping nature of the sea, that it was almost impossible for the men to keep their footing, and most of them, as well as the officers, were obliged to hold on by some part of the rigging.

I myself stood on the quarter-deck grasping a rope or a belaying pin, to prevent my being tossed from one side of the ship to the other.

When the storm had abated, each ship had to make the best of her way to port; and, casting anchor at Macao, three days after we had the satisfaction of seeing our convoy pass almost singly up the river to Whampoa, nearly all in a disabled state.

A little later I accompanied the captain to Canton, and at the residence of the East India Company's agent, or consul, remained two or three days, and was introduced to the captain of a 1200 ton ship, the Cirencester, with whom I was to take my passage to England. In their company was the captain of the Dedaigneuse, who I soon learned was about to take his passage home in the same ship.

The captain of the Indiaman, though bred to the sea, was a gentleman of quiet manners and pleasing address, and, coming north of the Tweed, was a tolerably good specimen of a commander in the E.I.C. service.

The captain of H.M. ship Derlaigneuse struck me as being of a higher order. His antecedents, in regard to a very lamentable affair, had gone the round of every cockpit in the British navy for now more than a dozen years, and had surrounded his name and history with a 
mist, or romantic halo, in which the real character of the man was not clearly perceptible to those who were scarcely out of their cradle when the tragedy in which this officer played so prominent a part occurred.

Independently of the circumstances of this extraordinary tale, which were but imperfectly known to us, he was considered a very smart officer-was rich in scientific acquirements, and had already begun to give proof of them in a nautical survey of the Indian coasts and in the construction of charts, to the great advantage of the service and the benefit of navigation. What wonder, then, that my curiosity should be excited!-or that I should seem to feel pleasure in seeing a person who had already made such a noise in the world, or rather had been so frequently of late the topic of conversation, in our little circle.

I found him a man somewhat, as I thought, over fiveand-thirty, a little above the middle height, attenuated in body, with every appearance of having suffered much from the climate, fatigue, and early and long exposure to the sun; his features were regular and pleasing, his countenance, though not strongly marked or even bright, was intelligent, his eye clear, his look penetrating; but there was at that time to my idea a depression or thoughtfulness on his brow, an habitual melancholy pervading all his aspect, that told, as I thought, of bygone and severe trials.

On my introduction but few words passed between us, but enough to inspire me with a respect that required something more than mere rank to account for. Some conversation must have taken place between my captain 
and this extraordinary person before I finally found myself accompanying him on the passage home, to which I must chiefly attribute his uniform kind and friendly deportment towards me.

It was not long before I took a final leave of my shipmates, and from the manner of their farewell I had reason to believe they were sincere in their hopes of my restoration to health and to the service. I shook each of the ward-room officers by the hand, one after the other; and fancied I saw a moisture in the eye of the plain, weather-beaten old master (Baker), with whom, for my little knowledge of navigation, I was a great favourite (he scarcely ever taking an observation without me), when he grasped my hand with both his own, and uttered his benediction on my head. The first-lieutenant, honest old Joe, as he was called, was not behind at expressing his regret at my leaving the ship; while the officer of my watch, who was more like a relative than a superior, while giving me an affectionate grasp, said he hoped on his return to England, which would not be very long first, that he should find me recovered and ready to join him in some other ship, where I might serve out my time, and then soon obtain my promotion. I replied sorrowfully that the nature of the malady that was written on my invalid-ticket would be a bar to my erer rising in the profession.

"Stop, sir, stop!" cried the doctor, who was reclining in the after-part of the ward-room; "remember that the greatest man that ever lived, Julius Cæsar himself, was similarly afflicted."

A smile played on my lips, though tears were in my 
eyes at this jeu d'esprit, if so it may be termed, of the doctor's, as I turned from them and made my exit.

The captain and the purser, of whom I had already taken leave, were on shore; and my chest and hammock being let down into the boat, I walked over the ship's side, not unobserved by my old friends, the captains of the forecastle and foretop, who stood waiting on the gangway, and doffing their hats begged to have the honour of shaking hands with me, as I had done with the gunner and boatswain; this I did with a full heart, and jumping into the boat had time enough to subdue my over-wrought feelings before I reached the Indiaman, which had dropped down from Whampoa that morning, and to whose captain I reported myself as his intended passenger.

The captain received me very courteously, and consigned me to the care of the third mate, who presided orer the secondary portion of the officer's mess-the first and second living entirely at the captain's table; it therefore consisted of all the junior officer's and an assistantsurgeon. With these I soon made myself at home, although I had to put up with no little bantering from one or two of them, who were foremost in evincing their jealousy and dislike of his Majesty's uniform; and I had to answer to a not very polite sobriquet derived from the name of the King's ship I had left.

We sailed, in company with my old ship, through the Straits of Sunda to Bencoolen, where the captain of the Dedaigneuse joined us. From thence we took our departure, in company with a large fleet of Indiamen, across the Indian Ocean, without convoy; and, 
after a good passage round the Cape, arrived safe at St. Helena.

We had not been at sea many days before the captain passenger called me on the poop, and requested me to assist him and the captain of the ship in taking a lunar observation. This I did so much to their satisfaction, that I was associated with them, in consequence of the protracted illness of the second officer, on similar occasions during the rest of the passage to England.

I must confess to having felt myself particularly flattered, as well as highly gratified, by this mark of confidence bestowed on one so young by an officer whom my little experience assured me was much in advance of his profession; and I could but admire the unassumed gentleness in his manner when, in casting up, or, in nautical language, working the observation and comparing the result, if there were any, the smallest, difference between us, which sometimes happened, though not frequently, he would never say I was wrong, but leave me to correct my own error or detect his.

Thus, with the conversation I would sometimes have with this experienced and highly-intellectual naval officer as well as noble and kind-hearted Christian, did my time pass agreeably enough, and met with no alloy from my messmates, who were in the main all goodnatured fellows.

In consequence of great depredations being committed on our commerce by the French Admiral Linois, in the Marengo line-of-battle ship, and her companion, the Belle Poule, a frigate that, from her sailing qualities, had bid defiance to our fastest cruiser's, we were detained at 
St. Helena nearly three months. During that time the late captain of the Deduigneuse, and the only other cabin passenger, a gentleman high in office in the East India Company's Civil Service, lived entirely on shore; while I, having no money, was obliged to spend my time in the best way I could, which was principally in fishing at different points of the coast of this rocky island, where mackerel and conger-eel abound, and upon which we almost entirely subsisted-as, from the great number of ships, it was impossible to get a sufficient supply of fresh provisions from the shore; and such a surfeit did I receive of this piscatorial diet, that it was years before I could be induced to touch either of those specimens of the finny tribe.

At length H.M.S. Athenienne, of sixty-four guns, arrived from England, to take charge of the largest convoy that had ever assembled at St. Helena; and after a fine passage, without meeting with anything worth recording, we arrived in the chops of the Channel.

A pilot-boat coming alongside, I resolved to take advantage of it and get on shore as quickly as I could. Accordingly I attired myself in the best my wardrobe, which had sadly diminished, would afford, and went on deck. The captain was standing on the poop with his two passengers. Going up and addressing him, I said that if he could dispense with my further services, I begged to be allowed to go on shore in the pilot-boat, as my friends lived near the coast, and I was anxious

1 This ship was in the following year lost, and the captain and all the crew perished, she having struck on a rock between Malta and Cape Pessaro, in Sicily. 
to get home, and proceeding to the Downs in the ship would take me considerably beyond it.

To this he politely gave his assent, and wished me good-bye. Turning from him to take leave of the naval captain I have already spoken of, he took me on one side, and casting an eye at the shabby state of my uniform, he said,-

"I am afraid you are not sufficiently prepared for" any immediate expense, as, from your knocking about from port to port in India, your unexpected return, and our long stay at St. Helena, you cannot have heard from your friends, therefore take this," he added, slipping four dollar's into my hand; "you can pay me when you see me, and if we do not meet I shall be no loser."

Now, considering that I had not seen the face of any coin since I left China it was not to be wondered at that I should be overcome by this act of disinterested generosity from a stranger to my family and connections. Remembering at the same time the kindness and attention I had received from one so much my superior in rank and attainments, I burst into tears; this was not unobserved by my liberal benefactor, when he again pressed my hand and bade me farewell. "Good-bye, Gramp!" hallooed the sixth mate from the port-hole, making use of the epithet by which he always addressed me, as I lowered myself down in the pilot-boat, when she almost immediately sheered off.

Now left alone on the deck, the reader would suppose I should have indulged in those pleasing anticipations that generally absorb the mind on such auspicious occasions. Not so with me; for however I might rejoice at once 
more being in sight of my native land, and on the threshold, as it were, of the happy home I had left, a feeling of regret, of depression, crept over my spirits, as I felt and contemplated the farewell I had just taken of my considerate friend.

There was something about the man that attracted and commanded my respect and veneration, if not my love, independently of the interest that one awful occurrence in his early life shed round his name, the distinction he had already gained in the service, or the reputation with which his superior scientific endowments had stamped him as an ornament to his profession. Something also told me that with such an excellent specimen of humanity and myself there could be no compare-that our destinies henceforth would lay wide apart-that my malady, which had been gaining ground, would ever prevent me following in the track of so distinguished a leader, and that I must solace myself with reflecting on my good fortune in having been thrown in the path of so eminent a man.

With the scene of that farewell deeply impressed on my heart, I fell asleep, as night came on, on the deck of the pilot-boat-and, reader, it has never been effaced. It was many months-I may say two years or morebefore I again fell in with my friend, and repaid him what he called the trifling obligation he had laid me under, when he took occasion to express his extreme sorrow at my having left the service.

He continued his brilliant career in the Navy till long after the revolutionary war, stimulating by his example the exertions of others, to take up, cultivate, and extend 
the knowledge of those branches of science that have served to raise and to adorn this noble profession. He has long since paid the debt of nature, dying at home in peace with his family, and has left behind him a name that ought to be recorded in the annals of the British Navy in letters of gold. For myself, I have ever cherished the memory of this highly gifted man with proud delight, and looked upon the limited, though I may say familiar, intercourse that passed between us as the greatest honour I have enjoyed during my long and varied existence. ${ }^{1}$

On my awaking in the morning, for I had slept soundly during the night, I found upon inquiry we were sailing up Southampton Water, with a flowing tide. On reaching the quay we were not allowed to land, not having received pratique from the quarantine flag at the Motherbank, more particularly as we had a sick person on board, the second mate of the Indiaman, who had been lowered down in his cot into the pilot-boat, in the last stage of consumption! Poor fellow! he breathed his last before we reached the Point at Portsmouth, where we landed after calling at the Motherbank, in preference to going back to Southampton.

Captain Peter Heywood. He was accused as one of the mutineers of the Bounty, brought to England, tried (with others of the crew) by a court-martial assembled for that purpose on board the flag-ship at Spithead, and sentenced to death. For a full and correct account of which, together with his correspondence on that occasion, his defence, pardon, reinstatement, and continued and brilliant career in the service of his country, see "Memoirs of Peter Heywood," as compiled and published after his decease by a near relative. 
When it came to my turn to get out of the boat, the master and owner of it, in a coarse, rough manner, demanded my fare. Accordingly I put my hand in my pocket and presented the four Spanish dollars my kind benefactor had so generously bestowed on me, when sweeping them out of my hand, with a greedy look at them and a contemptuous one at me, he said, "You are only a poor devil of a midshipman of a man-of-war," and left me penniless to my fate. ${ }^{1}$

I set my foot on shore, and looked round me with an almost vacant mind, not at all recalling my departure from the same spot; then slowly and moodily walking up Broad Street, through Point Gates, as they were called, into the High Street, I entered one of the principal inns. Here I was much discomfited at finding myself the object of the host's studied politeness, instead of his hearty greeting as I foolishly expected.

Just at the time when I was unable to disguise my perplexity, an old female servant of my mother's coming in, recognized me, when the tables were turned, and I received from both host and hostess a generous hospitality. From them I learned that the family were in London; and that my elder brother had left school, but was then in the town. He, on hearing from them of my sudden appearance, came and took me to my father's house.

And here, gentle reader, terminated my career on the ocean, whether for good or for ill it is not for me to say,

1 I had an opportunity a few years afterwards of recalling this gentleman to a sense of his politeness, when he called upon my father for a further loan on his vessel, upon which, at the time I speak of, the former had already advanced $£ 300$. 
but to bow, as I did then, to the decrees of Providence and to agree with the philosophic bard that "Whatever is, is right." With it ended the first stage or epoch of my life.

I returned to the bosom of my family, it is true, unsullied by the deceits, untainted by the follies, and unacquainted with the artifices of the world-uncontaminated, too, by those vices to which a sailor's life is inevitably exposed; but upon a careful retrospect I think I can descry the germ of those feelings and motives of action that afterwards brought no fruit to perfection: in other words, the impressions I received and the notions I imbibed were incompatible with success in any other sphere of life. 


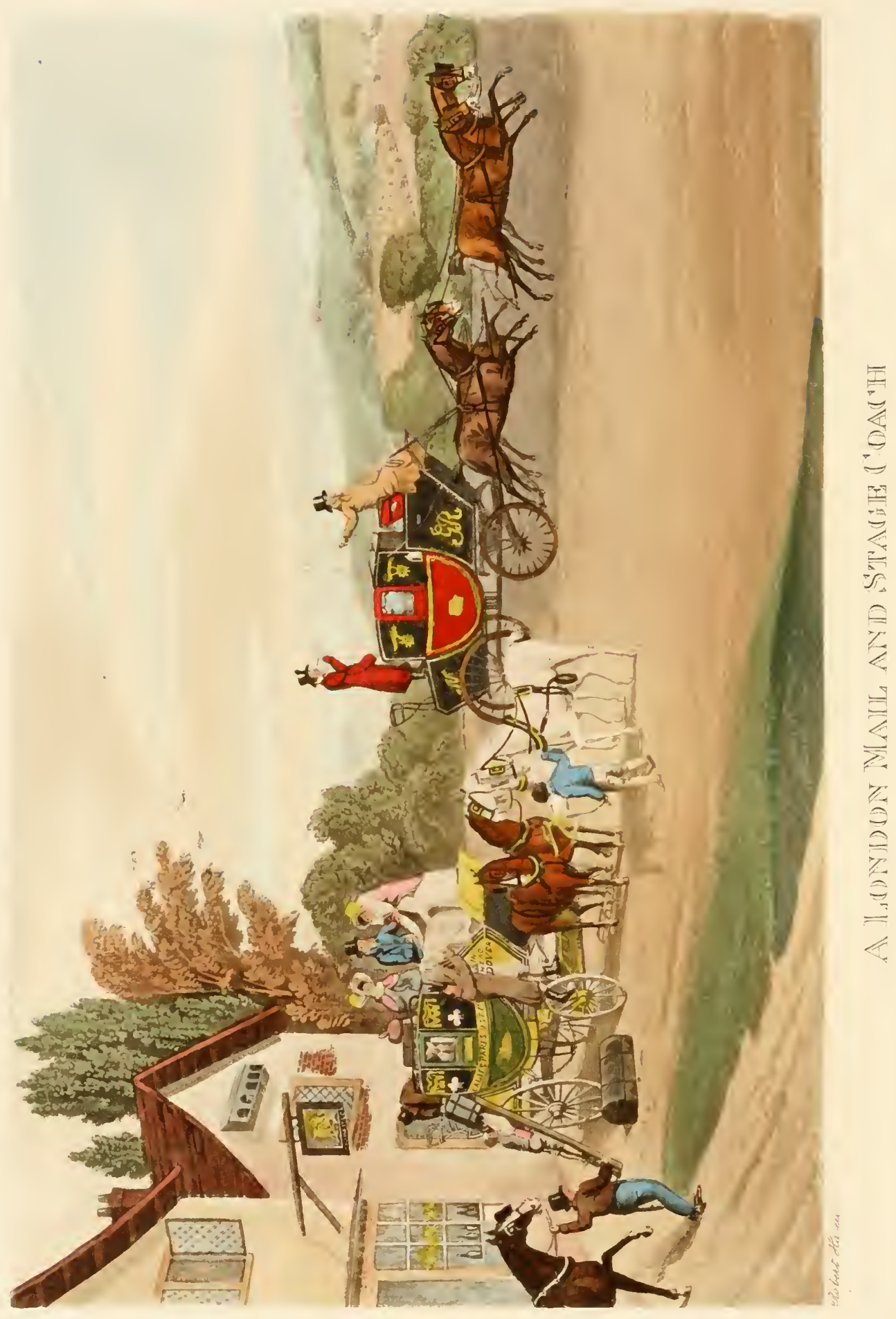




\title{
CHAPTER IV
}

\author{
THE CHANGE
}

A Coach Proprietor-Members of Parliament-A Welcome-Nelson's Funeral-The Theatres-George Frederick Cooke-John Kemble and Mrs. Siddons-The Country-A Death-bed Scene-An Elegy-The Lawyer-A Second Blow-The Wine MerchantA Third Blow-A Valetudinarian-The Postmaster-A Scene at the Dinner-table-A Consultation and Trial-Unexpected Result-Philanthropy.

IT is now necessary the reader should be informed that my father was a considerable mail contractor in the district where he lived; consequently largely embarked in the stage-coach business - a business or avocation as compatible with civic or even senatorial honours, excepting a certain desideratum, as a partnership in an extensive London brewery, or a Manchester manufacture, as subsequent events have shown.

The first among the few coach-proprietors who ever attained this distinction stands an individual who was originally a book-keeper in one of the principal coachoffices in London. ${ }^{1}$ Possessed of a dashing exterior, he managed to possess himself, by a matrimonial alliance, of considerable property; and, upon the failure of his employer, became sole proprietor of a large establishment. Connected with one stage as well as another, he

${ }^{1}$ Richard Ironmonger, Esq., M.P. for Stafford. 
contrived to insinuate himself into the favour of Richard Brinsley Sheridan, Esq., a thing not very difficult with men in affluent circumstances and armed with a little self-importance. Accompanying him in his frequent electioneering expeditions, he became known to the electors; and, imbibing a fatal ambition, upon the death of that brilliant but eccentric genius, he offered himself, as a candidate for the favour's of the shoemakers of Stafford; and, after some few rain attempts, succeeded in being returned for that intellectual constituency. Upon one of these occasions, when he had to exhibit himself on the hustings, his speech was received with hisses and vociferations of "Off! Off!" by his opponents. Then a wag in the crowd, a friend of his own, afterwards wellknown to the author, slily, audibly, hallooed out, "Off with his head-so much for Booking 'cm!" which elicited roars of laughter from both friends and foes. Poor man! he spent the greater part of his life in aping his superiors ; and when he at length attained the great object of his ambition, by being, as he thought, seated beside them in the great council of the nation, death put a stop to all further aspirations, or we do not know to what office the conspicuous talent of "The frothy gentleman of Leatherhead," as he was most aptly termed, would have raised him.

Widely different was the career as well as the attainments of another person who issued from the same establishment, and afterwards rose first to civic, then to parliamentary honours. ${ }^{1}$ Downright industry and a systematic application to business, in which the female members of the family were called to assist, William T. Chaplin, Esq., late M.P. for Salisbury. 
formed the foundation of his elevation. Well up in the practical part of his vocation, which he followed professionally for years, he had a very good knowledge of the animals he governed, as well as the bipeds with whom he was associated, and made them both subservient to his designs. With the employment of an oratory he could at all times most powerfully use, though it was not adapted to the atmosphere of St. Stephen's, he added an intellect superior to most of his class in shrewdness and tact, and this with a soft, oily expression, that procured for him the sobriquet of "Bite 'em sly." He possessed, also, a sort of playful sarcasm, he was fond of exhibiting, under which he disguised his real object; by these gifts he raised himself to eminence and procured a host of worshippers.

There were others who rose from the most menial situations, compared with these, to be members of the same august body. With wits sharpened in the lowest purlieus of an inn, they acquired in the north an habitual taste for railway transactions; and when the mania was at its zenith they snatched the opportunity of gaining a position that gare them such an amount of patronage as would at any time ensure their election for small constituencies, such as Salisbury, York, Bodmin, Harwich, and similar places.

"'Tis success that colours all in life:

Success makes fools admired and villains honest.

All the vain pomp and glory of the world

Wait on success and power, howe'er acquired."

At the time of my coming home from sea my father was in London, where he had purchased a very large VOL. I. 
establishment in his own line of business, at the cost of several thousands of pounds, of the frothy gentleman before spoken of, leaving my elder brother to superintend the business in the country; but he did not long remain there. He very injudiciously, as it appeared, took in as a partner the man who had not long before failed there; ${ }^{1}$ and he, to the best of my memory, took the first opportunity of getting out without any material loss. Better had it been for himself and his family if he had never returned to it, which he unfortunately did some few years afterwards. But let me not anticipate.

The morning after ny landing at Portsmouth I was sent off to London; and arriving in the evening, my father met me, and took me to his residence in the immediate neighbourhood. I shall not attempt to describe the emotions of my heart at once more being embraced by a fond and excellent mother, as well as by my elder sister, who had been my principal correspondent, and had been attentive to all my requests. I remained in town during the winter, almost daily visiting either Guy's or St. 'Thomas's Hospital, but my malady was at length deemed incurable. Consequently, my invalid-ticket was exchanged for a discharge from the Royal Navy, as I was considered, from the state of my health, incapable of serving his Majesty. My father, not satisfied with this, took me to more than one eminent physician, all, however, with the same result. Indeed, my malady seemed to set all medical aid at defiance, and it was thought best to let it take its course.

During my residence in London the funeral of the ${ }^{1}$ The late George Boulton. 
great Nelson took place; and I may here mention that my father was the last person who shook hands with the illustrious hero on English ground, having accompanied him to the Sallyport, and held an umbrella over his head, on his embarkation from Portsmouth, prior to the fatal battle of Trafalgar. I had, with some friends of the family, who had procured tickets, seen the body lie in state at Whitehall, and afterwards stood upon one of the sides of the arch of Temple Bar as the procession passed under.

I also frequented the theatres and other places of amusement; my father being intimate with the proprietor of Covent Garden, and holding shares himself in Drury Lane, I had many opportunities of witnessing the performances of those celebrated artists, Cooke, J. Kemble, and Mrs. Siddons, in, I may say, all their principal characters. Their inimitable representations put all other pretender's in the shade, while the dramatic hemisphere was illumined by the splendour of their talents.

I remember about this time to have met more than once or twice the great George Frederick Cooke (for great he was in his profession) at a dinner-party in London, in company with my parents, ${ }^{1}$ and had an opportunity of observing in private the most prominent characteristics of that deservedly popular, though somewhat eccentric, actor. In person he was inclined to be tall and athletic (on the stage his figure was majestic), with a countenance not handsome, at the same time not unpleasing, for there was a good-natured smile

'See "Memoirs of George Frederick Cooke," by Dunlop, first published in the United States. 
lurking at each corner of his mouth; while his large, dilating eye sparkled with hilarity, even in his most sober moments; but which expression he could quickly change into one of angry dispute or grave discussion, should offensive personality provoke the one or serious reasoning invite the other; indeed, sometimes his countenance would assume a malerolence of expression I hare rarely, if ever, seen surpassed.

In conversation, while sober, and I never saw him otherwise in the company of ladies, he was fluent if not eloquent-his manners bland if not polished-rich in anecdote, acute of understanding, bright and quick in repartée, slow but serere in his satire, generally just though approaching to sarcasm in his observations and conveying to the youthful mind a fund of pleasing in. telligence.

Indeed, I fancied I could discern in his stronglymarked features the wicked dissimulation, the unscrupulous ambition, and the princely dignity of Richard, the implacable hatred of Shylock, the malicious cumning of Iago, the worldly accomplishments of Sir Pertinax, and the comic irony of Falstaff. In all these characters he was not to be equalled; in one part only, in that of Si. Giles Overreach, in Massinger's play of a "New Way to Pay Old Debts," did I erer afterwards think that a ver'satile professor of the histrionic art, upon whom his mantle was made to fall, ${ }^{1}$ came up to the delineations of

I It was generally reported that at the time of the introduction of the elder Kean to a London audience, an assemblage of the principal proprietors and editors of the London papers took place at Holland House to favour his reception; but I cannot state it as a fact. 
this consummate actor. What a pity it is that such lofty gifts should have been marred by the most vulgar of vices!

It may be considered foreign to the subject, but I cannot quit this part of my life without recording my equal admiration of his more classic rival, more particularly in his Roman characters; and my youthful and afterwards my more matured adoration of his illustrious sister. Some actors, it must be acknowledged, have put forward pretensions to emulate the performance of the two former-the latter stood alone and remained unrivalled. Shakespere's Lady Macbeth and Mrs. Siddons have gone to the grave together.

After spending some months in London, without any benefit to my still declining health, I was sent to my father's residence in the country, where I spent my time principally in reading; for I had begun to acquire sedentary habits. Sometimes I employed myself in gardening; at others I was induced to accompany an affectionate sister in rambling over the neighbouring downs, and often in gossiping with and listening to the tales of the villagers; one of whom, I remember, was an old smuggler, who would amuse me with accounts of his feats of courage, or of cunning-telling

\footnotetext{
"Of most disastrous chances, Of moving accidents by flood and field, Of hair-breadth 'scapes."
}

Following no occupation, I became idle and listless.

Suddenly I was called away to the Isle of Wight to attend the dying bed of my elder brother. I have not passed through a long life without having been much 
subjected to these sorrowful visitations of Providence: in every relation of life, as a son, a brother, a husband, a father, have I had to bow to the decrees of the Almighty, and with becoming fortitude and resignation bear the grief inflicted by His chastening rod; but this was the first, and it is not to be wondered at if it made a deep and lasting impression on my then youthful heart.

The shock which the mind receives from the death of a near and dear relative, cut off in the bloom of health and pride of youth, makes it loth to surrender its grief, even to the growing incidents and allurements that time may throw in the way, particularly where there is little else to dwell on.

He was a fine handsome promising youth, in his eighteenth year, endeared to the family circle by a most amiable disposition, and, by his manly and generous conduct, had won the admiration and enjoyed the friendship of many per'sons of his own age and station. He was on an excursion of pleasure round the Island, with two or three others, prior to their entering on their studies necessary for the profession each of them had adopted. He was a most excellent swimmer, but imprudently, without a thought of the consequences, under a noonday's sun in the autumn, undressed after a long ride on horseback, and plunged into the sea, to indulge in his farourite pastime.

How he was first taken I do not know; but I found him in a cottage at Shanklin, in bed, with a burning fever-attended by our weeping parents and our elder sister-which, in a few days, proved fatal.

This was a severe blow to all; though I remember my 
sister then first manifested that spiritual endowment which she has had occasion to exercise in so many similar instances, and which has earned for her the enduring love and esteem of her numerous relatives. My brother's remains were interred in a vault my father had built for the purpose, in our parish church of Catherington, and were attended to their last resting-place by his sorrowing relatives and his most intimate companions.

On the Sunday following, I remember, a most impressive discourse was delivered by the parochial minister, ${ }^{1}$ whose eloquence not only reached the heart of those nearly allied to him, but drew tears from the eyes of the rustic congregation.

The following lines, written by one present on that solemn occasion, and afterwards sent to my elder sister, will give some idea of the loss we all sustained, and at the same time do credit to the writer's mind and heart as an elegiac production :-

\section{LINES WRITTEN BY EDWARD BINSTEAD,}

A FRIEND AND COMPANION OF THE LATE — - WHO WAS A IITNESS TO HIS END, AND AGAINST WHON INJURIOUS REPORTS HAD BEEN FALSELY CIRCULATED.

WhILE sad remembrance paints the scene of woe, My tortur'd breast its anguish will reveal;

In spite of consolation tears will flow, And silent tell the poignant grief I feel.

Scarce had he to meridian beauty rose,

When, in a sudden and eventful hour,

He sunk eternal to that long repose

Where mortals all must yield their boastful pow'l.

1 The Rer. G. G. Griffinhoof. 
Twas then that calumny, with poison'd breath,

To malice lent her pestilential aid,

And falsely said that in his lingering death

That friendship, inhumanity betray'd.

Ah! who can feel his grievous loss more dear,

Or at his melancholy fate repine?

Friends of his youth might drop a genuine tear,

But all their sorrows cannot equal mine.

For may I not superior sorrow claim,

Who knew his worth, and saw the pains he bore?

Parental woe might know a pang the same,

But e'en their misery cannot feel it more.

Intrusive thought! why wilt thou piercing steal

To paint the hapless day that snatch'd him hence?

Reflections here a train of woes reveal,

And grief's increas'd by funeral eloquence.

Not all the ills that sympathy had taught

That solemn scene, when to the hallow'd shrine

I follow'd him: not then such grief had brought

As that inflicted by the good Divine.

Each village rustic felt its solemn force,

For each had known the virtues of his mind;

Affliction's tear fell from its native source,

And all the neighbouring train in sorrow join'd.

Pensive where rest his ashes will I stray,

When evening spreads its melancholy gloom

And through the village churchyard bend my way,

To heave the sigh of sorrow o'er his tomb.

Not long after this visitation of Providence it was thought necessary that I should follow some profession: and my father, observing my studious disposition, articled me to an attorney. The person selected for my governor, or instructor, in this, what ought to be, honourable profession, was a plain, plodding country lawyer, of good family and connections, in excellent repute as a con- 
veyancer, and, what is more rare, a man of probity and honour, to whom many of the neighbouring gentry committed the management of their affairs, and whose general practice did not descend to take part in those disputes that, arising from the frailties, the vices, or the misfortunes of mankind, give employment to the talents and virtues of the greater part of the practitioners in what is termed Common Law.

He was also a man of an equable temper, not easily provoked, of a kind and friendly disposition, devoted to his family, and a most lenient master. He had, I remember, an excellent library, in which I used to spend my time out of, and frequently in, office hours; for there was more attraction for me in the perusal of our English classics, particularly Dryden and Pope, than in studying the dry disquisitions of Hale, Coke, or Blackstone.

But my progress, whether slow or otherwise, was suddenly cut short. My governor having stepped out for a few minutes while the other clerks had gone to their dinner, and leaving me alone in the office, on his return found me in one of the dreadful fits that had so long afflicted me; and what made it worse, I was attacked so near the fire, that, had he not returned as he did, I must have been burned to death; as it is, I carry the scars of the wounds about me I received on that occasion to this day.

This had such an effect on the nerves of the good man, that he requested my father to take me lome, as he dreaded the responsibility he had incurred by taking charge of one in so precarious a state of health, and most 
honourably returned the very considerable premium my father had paid with me.

I cannot say I felt any regret at leaving, for I had no fondness for the profession, and my malady had already begun to make me indifferent to any constant employment.

Accordingly I was taken home-but not to our house in the country-again to spend my time in idleness; for soon after, or about this time, my father had, for what cause I know not, except with a view to provide for meembarked largely in the wine trade. Importations were made from Oporto, Cadiz, and other foreign marts; and the large cellar of our house in the High Street was well stored with wines of every description, and of the choicest vintage; for my father was considered an excellent judge, and had good connections, both in the army and nary. The whole was committed to the care of an experienced cellarman, long known to the family, to whose charge, as regarded my health, and a watchful observation of my movements, I was also consigned.

Everything went on well for some little time, and a good trade had already been established, when one day I was down in the cellar superintending-or, rather, in company with the man, for I could only look on-the bottling off a pipe of port. The cask had been drawn off, the bottles arranged in regular order ready for corking, when suddenly, without the smallest notice, I fell crash among the bottles, breaking and destroying a considerable number, and lacerating my hands and face awfully with the fragments, till the floor of the cellar was absolutely flooded with the generous liquor, not unmixed with 
some few drops of what was more precious to me, and the loss of which added not a little to my already weakened state and now woeful appearance.

On the arrival from the country of my father, who was speedily made acquainted with what had occurred, the cellars were closed, and in a few days the whole genuine stock of wines was offered for sale. They were eagerly purchased by an old-established wine merchant in the town, who was glad to get rid of a formidable rival to the monopoly of which my father had already committed a great inroad.

After that calamity all thoughts of my ever being fit for any profession or employment were abandoned, and I was kept at home, under the watchful care of one or other of the family, who never suffered me to go out of his sight. I now became sensible that I was a burden to those about me, although the most constant and tender attention was bestowed on my every movement-indeed, on my every look; and I was fully alive to and grateful for this affectionate solicitude. But my spirits sank with my health; and, giving up all hopes of partaking in the enjoyments of youth either mentally or bodily, and losing all inclination for society, I acquired a silent and melancholy manner.

It was early in the year 1807 that a new postmaster was appointed at Portsmouth, in consequence of the death or superannuation of one who had grown old in the service. An office of such considerable importance and responsibility-consequently one of good emolument -was bestowed on a gentleman closely connected with the Baronet (Sir Francis Freeling) who so long and so 
efficiently fulfilled the office of Secretary to the Postmaster-General. He had not long taken possession of his new appointment before my father called on him, as it was quite necessary, from the relative situation he stood in with the Post-Office as Mail Contractor, that they should be known to each other, if not be on friendly terms. This induced a reciprocity of visits; and my father, with his accustomed hospitality, took an early opportunity of inviting him and his family to dimmer. They accordingly came, and, while seated at the table, the whole party were suddenly discomfited by an attack of my fearful enemy - for fearful were the distortions of my countenance in all such lamentable visitations. I was borne to my room, and did not again make my appearance that evening; but I understood that I and my dreadful malady formed the topic of conversation in my absence. Indeed, on my recovery, my sister told me that the gentleman had evinced great commiseration for my aftliction; and in the course of conversation, after asking many questions as to its general nature and origin, said he was acquainted with a person in London who he was sure could cure me.

This drew a smile of sorrowful incredulity from the lips of my father, who, after having sought and had the best advice the most celebrated of the faculty could afford, had no faith in the ability of any unknown doctor or acknowledged empiric. My mother was not so disinclined, but listened with avidity to the many instances of successful trials our new acquaintance cited and upon which he founded his conviction that, were I to take his friend's specific, I should at no very distant date 


\section{A SPECIFIC}

be restored to health. In the morning he called to ask after me, and again took an opportunity of imploring my parents to try the remedy he had named, or, at least, to allow him to write to the person to ask his opinion of my case. He then appealed to me, who had long despaired of any remedy, and I avowed that I should do exactly as my parents wished, but gave him to understand I should have no faith whatever in any medicine his friend or any one else might prescribe-at the same time kindly thanking him for the interest he had evinced for me.

At length, after frequent importunities, he prevailed and obtained both my father's and mother's permission to write the particulars of my case to the gentleman he had named.

In due time an answer came to say that he had considered my affliction, and had not the least doubt that, with the aid of the Almighty, if I persevered and took the medicine which he from time to time would send me, I should eventually be restored. This, he said, might not occur till after an interval of three, six, or nine months, and we were not to be alarmed if my fits became more frequent and lasted longer. $\mathrm{He}$ assured us that eventually they would quite leave me, and a permanent cure be effected.

I commenced taking the medicine early in February. The professional gentleman who had attended our family for many years-a man of good understanding and extensive practice-on his first visit put his tongue to the liquid, which was of a most nauseous nature, shook his head in ignorance of its qualities, but said not a word to discourage us in the trial of it. 
The spring had passed away, and the summer brought with it an aggravation of my malady - that is, my fits had become much more frequent, and the convulsions of longer duration; so much so, that the family became alarmed, and our medical man, who had watched its effects and began to fear the worst, advised us to discontinue following the prescription.

Accordingly a letter was written to that effect, to which an answer was returned (and which is now in my possession), urging me to keep on with the medicine, stating that the result hitherto was no more than he had predicted, and quoting a similar case, where, under similar circumstances, it had recently proved successful.

A long discussion now took place, and various and contradictory were the opinions given. The gentleman who had first recommended the trial, and had since shown a keen interest in its progress, having every faith in his friend's panacea, urged its continuance-my mother doubted, while my father, the medical man, and my late instructor in the law, who happened to be present, and had not ceased, nor ever did cease, to take a lively interest in my welfare, said it had better be given up.

At last it was determined to leave it to myself; while I, having been some time convinced that it was a desperate remedy, and feeling that life with the prospect of an impaired intellect would not be worth possessing, decided instantly on going on with the medicine. This was in July. Another month had scarce elapsed when a day passed orer the time in which I was usually attacked -then another, and another. My sister and my mother 
looked at each other with surprise, not daring to express the hopes that had begun to possess their minds.

A week passed without my being at all affected, and it was thought advisable to apprise the gentleman in London of so favourable an occurrence. To this no reply was received; consequently, at the end of the second week another letter was dispatched, stating that I still remained free from any further attack of my late distressing visitor, and begging to know if I were to continue the medicine.

On the 9th of September a letter was received, which announced my cure; and from that time to this I have enjoyed, through the blessing of Providence, almost uninterrupted good health. It is but justice to add that this gentleman (whom I never saw, for he died a short time after) in his letter congratulated me on my recovery, but took no credit to himself, and impressed on me how much I was indebted to the goodness of God, who had made him the means to rescue me from that idiotcy to which I was fast approaching, and for which I never could be too grateful.

Upon being applied to for his charge, he some time afterward enclosed the apothecary's bill, amounting to 15l. only, and stated that he was satisfied in being the instrument whereby such good had been done to his fellow-creatures. An instance of true philanthropy, of rare occurrence, and I think worth recording: although the logic made use of by those of the faculty, who at the time derided the means of cure, as well as other practitioners of the present day, who deny the existence of the malady in my case,-may not be. 


\title{
CHAPTER V
}

\author{
EARLY LIFE
}

Convalescence-Thoughts for the Future-The Sixth Mate-Amusements-A Rash Adventure-A Literary Society-Junius-Lord Macaulay-A Charactel-A Fire-Gunpowder CompanionshipLord Gambier-Sir Eliab Harvey-Sir Roger Curtis-Lord Cochrane-A Curious Rencontre-The Prince of Wales-A Dreadful Explosion-Wonderful Escape-A Rash Attempt.

Euerging from this long course of sickness and despondency, I did not, as many would suppose, immediately mix in the affairs of the world-its pleasures, its business, its allurements, or its follies. It took some time to renovate my strength. My constitution, which must have been sadly torn and weakened by such repeated violent attacks, required care and attention to restore me to anything like convalescence, and to enable me, both in body and mind, to become a member of society at all. Consequently, a year passed away before I sought any companions or followed any business.

During this time many were the projects thought of, and plans laid out, for my future. The first question mooted was, would I go back to the profession I was so fond of, and in the scientific part of which I had made so much progress? Alas! that had. all vanished, as well as other acquirements, owing partly to the want of practice, and partly-indeed chiefly-to the malady, that had so 


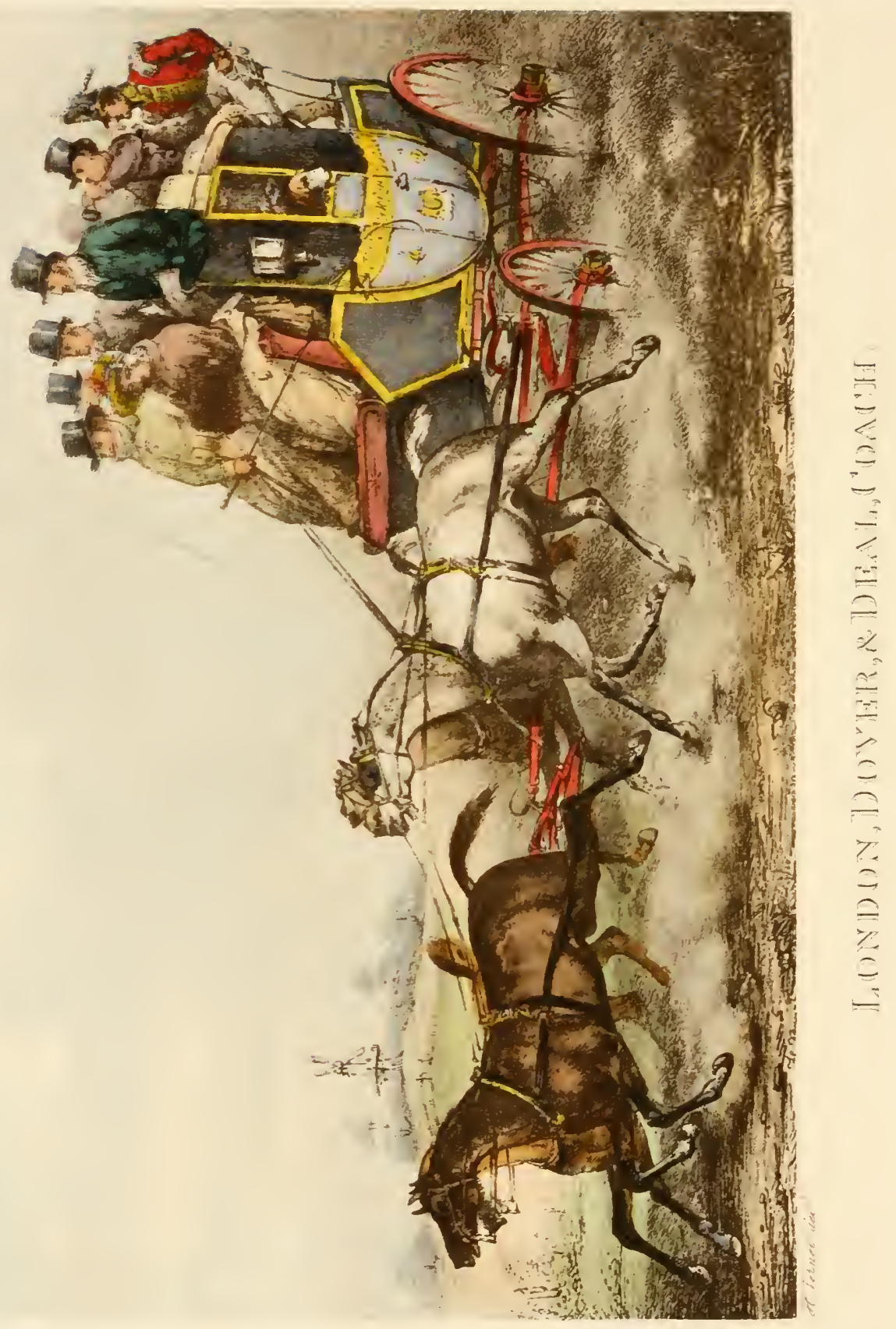


affected my brain as to deprive it almost of the power of retention, and to dissipate the fruits of early application, and fair natural capabilities.

To this return I clung with an eager tenacity, although with groundless hope, till learning from a high quarter that, having received my discharge, the time I had already served would not be allowed when I should attempt to pass for a lieutenant, the idea was abandoned; and the gentleman, who had some interest at the Admiralty, and had kindly exerted it for me, observing my predilection for the Navy, offered to procure me a commission in the Royal Marines. But I had, as a midshipman, foolishly imbibed the dislike to that corps that had long existed in the cockpit; therefore, I immediately declined the offer.

Would I go back to the law? My racancy had long been filled up, and I could fancy no other masterneither had I any affection for the profession. Another thing, and that which mainly contributed to my remaining at home, was the loss of my elder brother. I had now become the eldest son; consequently my parents did not promote any plan that would require a long absence, or expose me to the risk of any return of my recent affliction.

Thus, then, did another twelvemonth of my life pass away, the monotony of which was now and then relieved by the visits of some early friends of my father; among others an old-fashioned gentleman from Cambridge, I remember, with his daughter and son. The latter had just then been appointed to the command of a sloop-ofwar, and erer afterwards made our house his home when

YOL. I. 
his ship came into port. I also saw some relatives of my mother's; and once my home was enlivened by a short visit from my old friend the sixth mate, who amused our family circle with his quaint expressions, and his bluff, sailor-like manner-for, though a rough diamond, he was a genuine, straightforward fellow, and had always possessed my regard. He was at that time second officer of the H.E.I.C. ship the Elphinstone, and boasted of having gone round the Cape twelve times outward and homeward without carrying away a spar-so little danger was there in a life at sea. Poor fellow!-he at last got killed by the natives in the Straits of Malacca, when going on shore for wood.

Advancing to manhood, it is not to be supposed that I was free from those little indiscretions to which youth is prone, nor is it necessary to particularize them. It may be enough to acknowledge that, in the language of the present day, I might be considered rather a fast young man. Being, as it were, the representative of my father, who held a respectable position in the town, and having the management or superintendence of an extensive concern conficled to me, I had a liberal allowance, and a good horse to ride; this was the more necessary, as I had to visit the different stages where the horses stood. Such out-door exercise proved beneficial to my health, so that I began to shake off all effects or fear of my late malady. Among other things, I joined a cricket-club, principally composed of officers in the garrison-this was the means of my introduction to a new and wide field of acquaintance; and then I partook of, and entered with spirit into, all the manly sports and 
pastimes then in vogue, including cock-fighting and bull-baiting, which had not then been abandoned.

I also joined the Yeomanry Cavalry, at that time commanded by a son of the East India Company's agent at Portsmouth; ${ }^{1}$ and as $I$ had the means of mounting my principal clerk as one of the troop, and my foreman in the stables as a trumpeter, I was pretty well recommended to the notice of the Colonel-commanding and the Adjutant, the latter being an intimate friend of our family. These arocations extended my acquaintance among some of the most flourishing tradesmen in the town, as well as the leading farmers and dealers in the country. Among the former was a man some few years older than myself, who was the sergeant-major, and a very efficient soldier he was; being a good swordsman, as well as a most excellent horseman.

Of these qualities he had given me a proof, which was the cause, if not the commencement, of our friendship. Being in London for the first time since my recovery, I determined to see the Derby, for which purpose I borrowed a nag from a well-known horse-dealer in London, with whom my father was acquainted. The animal on which I was mounted threw me three times between Bethlem Hospital and Epsom, and was altogether a restive and unruly brute. Meeting the sergeant-major ou the Downs, with an intimate friend of mine in a gig, they observed by the dust on my coat that I must have had a fall; on my telling them how I had been served, he volunteered to ride the mare home, while I should take 
his place by the side of my friend; to this I readily assented, and aided by a heavier weight and a stronger nerve, which his confidence as a rough rider gave him, he took the mare safe to her owner's stables.

He was also of a gay and convivial disposition, and our inspections and field-days on Portsdown Hill were sometimes wound up with a good feed, and an evening devoted to a rather tumultuary sacrifice to Bacchus. But this would only happen when we dined en troupe; on other occasions, after being dismissed, we would ride home together in small parties, each selecting his own fancy "Public" on the road for refreshment or enjoyment. Generally I found myself side by side with this sergeantmajor, for he was a congenial spirit, and we were associates in many a pleasurable gathering in the Isle of Wight-always a favourite spot of mine, in consequence of the genuine hospitality I received from many of its inhabitants-where business and pleasure frequently led my friend. One day after drill, we took our chop at the principal house in the village of Cosham, substituting brandy-and-water for the more genteel and customary bottle of old port. This was a bererage I was then but little acquainted with; howerer, we mounted at dusk, to ride gently and quictly home.

We had proceeded in friendly chat uninterrupted about half way, when I heard the sound of music; and as we approached the house or inn from which the dulcet notes proceeded, we discerned by the lights a large party of both seres tripping it on the light fantastic toe, in a lofty room in rear of, and partly orer the bar, the access to which was by wooden steps from the road. Without 
a moment's thought of the danger or the consequences, whether instigated by the rather unusual quantity of spirits I had taken with my pipe, or prompted by an innate love of mischief, I, without checking her, guided my high-spirited but well-trained black mare up the steps and in at the door. My friend, at all times ready for what is now vulgarly called a lark, followed me; and there we sat, erect in our saddles, our swords drawn, and our pistols in the holsters, to the amazement and consternation of the whole party.

After the screaming of the softer sex and the uproarious laughter of the other, which so foolish an exhibition had at first elicited, had somewhat subsided, our first consideration-for we had none before-was how to beat a retreat from an assembly whose numbers were overpowering, and whose merriment, I began to suspect, might speedily be changed into anger at our rash and indecent intrusion. The company consisted chiefly of dockyard mechanics, "their sweethearts and spouses," always a formidable body, and ready to resent any such impudent and outrageous innovation on their evening's amusement.

Nevertheless, preserving my presence of mind, I very deliberately dismounted, and taking hold of the mare's bridle, with a soldier's step, caused her to keep pace with me down the rude and ruinous staircase we had but a few minutes before recklessly ascended. The sergeant-major, following my example, was equally successful in gaining the road in safety, and our dangerous frolic ended in treating the whole assembly with sundry bowls of punch (we were none of us niggards on such occasions), which 
seemed to allay the pugnacious spirit of some of the party, who had evinced a strong inclination to bestow on us that sort of punishment our mad attempt at fun had so richly deserved; and this perhaps was in a great measure prevented by the superior tact and determination of my companion, who personally knew several of the men. As if to aggravate my offence, standing in the crowded bar, my spurs and sword became entangled in some choice dresses that lay in one corner of the floor after a day's bleaching, which roused the indignation of the landlady; and no doubt a summary ejectment would have been effected had I not hastily made my escape, mounted, and rode off. The sergeant-major soon followed and overtook me, and after congratulating each other on the result of so foolish an adventure, we said "goodnight."

On the following morning I called and made my peace with the landlady, by liberally paying her demand for all damages sustained. ${ }^{1}$

1 On a recent excursion for the benefit of my health, I by chance entered an inn in a market-town in Sussex. A gentleman, with hoary locks like myself, sitting with a pint of wine before him, attracted my attention. I felt convinced I had seen him before, and, after strictly scrutinizing his features, I recognized my old friend the sergeant.major, although I had seen him but once in forty years. Addressing him rather abruptly, I said, "If ever I saw E. G. I see him now!" He rose from his seat, and said, "You are right, sir, but I have no recollection of you." I asked him if he was not once a non-commissioned officer in the Hants Yeomanry Caralry. He said, certainly. I then recalled this incident to his memory; he instantly grasped my hand, and, shaking his head at the same time, said, "Now I know you, for none but T. C. would have led the way; and I never pass the house," he added, "without a vivid recollection of all the circumstances, and the danger we were in, as well from the crazy state of the building as from our wanton indiscretion." 
But with all this, I sought and kept good society. The family living almost entirely in the country, I had many leisure hours to dispose of ; and preferring the company of my elders and men of good position in the town to those of my orn age, I was induced to make one to join-indeed to found-a literary society, after the manner of the one mentioned by Benjamin Franklin. We were in number about seren or eight, all married. men but myself, and I was at that time under twenty years of age. It was our custom to meet every Monday evening, at the house of one of our members, who possessed an extensive library. The chair was taken by rotation, and the president elect would name the subject for discussion on the ensuing night of meeting-thus giving us all time to study it, and to form our opinions upon it, which we delivered extempore, or from a written paper, as we chose. The discussion ended, and our different opinions recorded in a journal kept for that purpose-which journal, by-the-bye, is now in existence -the president would read something of his own selection, either in prose or verse, from the best English authors, generally in accordance with the subject we had been debating.

I look back with no small degree of satisfaction at this part of my younger days, as it was not time ill spent-indeed, the employment was both rational and instructive; and I have lived to see institutions much resembling our little society grown up in many of our populous towns and districts. It tended also to improre those faculties with which the Almighty had endowed us; and if not of practical utility in erery-day life, it 
strengthened our sphere of knowledge; with me in particular, it helped to invigorate the mind, and to reinstate it in its former fondness for literature.

I remember about this time a weekly paper was published in London, called the Independent Whig. Its name alone was indicative of its politics, and in its attacks upon the Government it went much further than any other publication, Cobbet's Register not excepted. As I often found time to stroll into a bookseller's shop to read the London papers, the proprietor of which was one of the "L. S.," as we were called, par excellence, I used frequently to see this paper, and was more than once struck with the great similarity there appeared in the style of its leading articles (if the large type in the first page may be so termed) and the letter's of Junius; and when I read the one that contained so severe an attack on the Duke of Cumberland, and stated that H.M. King George the Third would shortly be called upon to perform the part of a Roman father, I was assured of the identity. It was generally understood at that time that Sir Philip Francis, then an old man, and living in St. James's Square, was a contributor to the Independent Whig; and Mr., subsequently Lord Macaulay, has since endeavoured to prove that he was the author of Junius. In proposing this for discussion at our little society, I could not get any one to listen to my conclusions; as, in the first place, I was not yet sufficiently qualified to judge of style, after comparing one with the other; and, in the second, they all asserted and agreed that the author of Junius had been dead many years. Although I could not give any further evidence in favour of his identity, I 
could not be diverted from that opinion-an opinion which I ever after maintained, and which I see confirmed by the first critic and historian of the age.

I shall not attempt to give a description of each individual member of our little institution, but shall say at once they were all men of intellect and education, well known in their different vocations, and commanded, or rather held, a highly respectable position among the community of which they formed a part; nevertheless, I cannot refrain from drawing an outline of one, to whom I was particularly attached, who was the original projector, as well as the hospitable owner of the house where our meetings were held-of one who afterwards attained to some distinction, and rendered considerable service to the Goremment in the Colonies, and one of whom it may be justly said that, for many excellent qualities, "we shall not look upon his like again."

He was in person abore the common size, tall and stout, well-made and strongly knit, his figure, without being graceful, exhibiting great bodily strength and activity. Nature had endowed him with an excellent constitution, and great powers of endurance. Few could come up to him in walking, running, jumping, skating, or any commonly practised gymmastics. His countenance was in unison with his frame; for, without being handsome, it was expressive of quick determination and manly resolution; while his full, piercing gray eye, gleaming from an iron complexion, surmounted by dark, crisp, curly locks, denoted a temper perhaps more rehement than ductile; in a word, he had all the fortiter in ie, without that admixture of the sumriter 
in modo, necessary to make what is called an amiable man.

"I do not know what this young man means," said Sylla, putting his hand upon the head of Casar; "but what he means he does with vehemence." 1

And this characteristic, if small men may be compared with great, may justly be applied to my friend. His manners were not so engaging as they were open and ingenuous. In conversation, he was more dictatorial than agreeable; in argument, more dogmatic than convincing; and yet was not impatient of contradiction, and would yield like a lamb to what he had contested for like a lion, when he found his position no longer tenable; and, generally speaking, his information upon most matters was good, and his observation just.

He had an excellent taste for literature, though it partook more of the grave and instructive than the polite and amusing. He had also imbibed a strong predilection for the sweets of gastronomy, which gave a zest to his hospitality; and, among those who knew him, did not detract from the pleasures of the table-in short, he had all the peculiarities of a thorough-bred Englishman; and one of his particular though perhaps not the wisest of his maxims was, that nothing should be done-no houses or acres bought and sold-no bargain made-no election, whether of mayor, members of Parliament, or churchwarden-no meeting, without a good dimner. With all this he was a man of sterling merit, strict integrity, undoubted truthfulness, uncompromising rectitude, sturdy

1 Plutarch's "Life of Julius Cæsar." 
independence, and strong, natural good feeling towards his fellow-creatures.

He possessed a fair share of oratory; could express himself with energy and eloquence, if not with brilliancy; was of sound understanding, well read in history, more particularly that of his own country, her laws and institutions. He was of inflexible purpose, not easily daunted; but doing all that became a man when circumstances rendered a decided action necessary.

As an instance of individual bravery I may mention, that one evening, nearly at the termination of our meeting, we were suddenly aroused from our discussion by the cry of "Fire!" proceeding from the street. We all immediately rushed to the front-door, when we found a large ironmonger's shop and house, a few doors down the street, on the opposite side of the way, becoming a prey to the ravages of the flames, which were fast issuing from the windows of the first and second floors. We had not stood long gazing at the fire, before an alarm ran through the crowd that there was gunpowder in the house; and one of the assistants in the shop came and whispered the fact to my friend, who, having ascertained in what part of the house it was deposited, and the quantity, immediately cried out, with a stentorian voicefor that was a gift Dame Nature had liberally bestowed on him,-

"Will any man go up with me, and bring the powder down?"

I was standing by his side, and felt as if the challenge was meant for me; but my heart sank within me as I contemplated the little chance of success. A few seconds 
only elapsed before a corporal of marines, who stood a few yards from us, responded, "I will, sir!" and came forvard.

"Don't-pray don't!" said I to the first; and his other friends, taking hold of his arm, implored him not to rush into such imminent peril. He shook us off, and, followed by the soldier, he was seen to enter the house by the private door, and heard ascending the staircase. A breathless silence pervaded the crowd, which now amounted to between two and three thousand. Those who were at work at the engines stopped, and stood in the attitude of fearful expectation-all waiting the result with the most intense anxiety. Those who anticipated the explosion held their breath with fear, while some ferw whispered a prayer for the safety of the two who had so hopelessly rushed into danger. As for me, I looked round to the house we had just left, where dwelt his wife and two sweet children, and could think of nothing but the mournful fate that awaited them: when suddenly, after a fearful absence, a loud hurrah anmounced that they had issued safely from the house, each bearing on his head a cask of gunpowder. These they carried safely to the guardi-house, distant about sixty or seventy yards, and there left in charge of the officer on duty; and then they returned to receire the cheers and congratulations of the crowd on the success of their hazardous enterprise.

The engines now played with redoubled force, the fire was soon subdued, and its ravages confined to that one house.

'This exemplary act of courage, showing a disregard of danger when a great calamity was impending, raised him 
very much in the estimation of the whole community, and he long held a commanding influence in the town; for he could at all times raise or control the vox populi, whether at a political meeting, or any other public occasion-such as a day set aside for rural sports and rejoicings, in which all classes would join, and of which he always took the direction.

I have been thus prolix in a tribute of respect to one of my early friends, as I consider his merits and qualifications would have done honour to a higher sphere than that in which his lot was cast. He still lives in the author's friendship and esteem, and maybe seen in London, after a long, toilsome, but to him not weary pilgrimage, wending his way with a slow, somewhat altered, but not yet crippled gait, towards the British Museum ; or seated in the splendid library of that magnificent establishment; as upright in his stature as in his mind, waiting with the same undaunted spirit-and, it is to be hoped, with that humble reliance on the merits and mediation of One who took our nature upon Him, and died for us all-that fiat that must shortly remove him "to another and a better" world."

With this friend was I associated in everything that was worthy of observation, and with every occurrence of importance, in the naval and military departments. Was there a ship-launch in the dockyard, we were there; was a line-of-battle ship-a first-rate-going out of or coming into harbour, we were on the platform to witness the magnificent spectacle; was there a regiment of the line about to march down the High Street to the Sallyport, to embark for foreign service, we were sure to meet them 
at the Landport Gates, and accompany them, keeping time to their martial music ; did a detachment of invalids, sick or wounded, disembark, we were on the beach to receive them; did a bull-bait take place in the neighbourhood, or a cock-fight call us out of town, we were there too. Of the first, I may say I nerer witnessed but one; but the picture of the maddened beast, the sleek and courageous dog tossed high in the air-his master, running with outstretched arms to catch him-while his entrails protruded from the orifice made by the horns of the foaming and bellowing bull, the tears of anguish shed over his pet friend and companion by the man who had trained him to the cruel sport, of which he had just become the victim, convinced us both that it was a most degrading pastime. The other, though of an equally demoralizing nature, did not appear as brutal in its character, and did not attract such low company.

There was a gentleman in the little town of Bishops Waltham that annually had an exhibition of this sort, who generally had some first-rate birds, and we were in the habit of meeting there some of the first people in the neighbourhood.

On one of these occasions I remember two men, who had the appearance of gentlemen, but were nothing more than London black-legs, as was afterwards ascertained. They refused to pay some debts I had fairly won of them, so I unceremoniously horsewhipped them out of the pit.

But from these peccadilloes of a youthful spirit, fond of seeing life in all its phases, let me turn to what perhaps may be more interesting to the reader.

Among other remarkable occurrences of this time was 


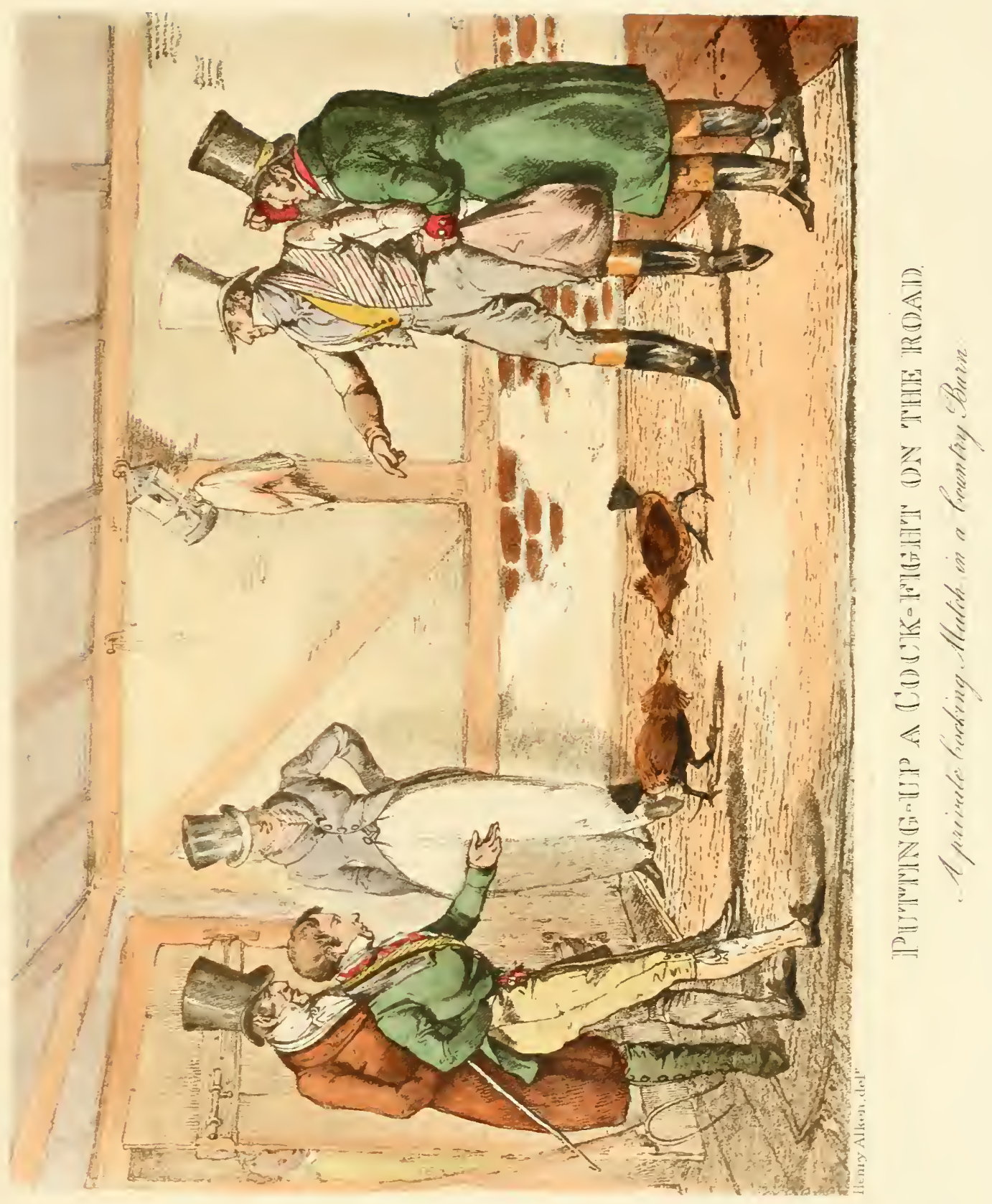


-

. 
that of three courts-martial held in succession on three distinguished officers of the naval service, all arising out of the same operations against the enemy-Lord Gambier, who had the command of the Channel fleet; RearAdmiral Sir Eliab Harvey, Bart., commanding the inshore squadron, blockading some French line-of-battle ships and other vessels in Basque Roads, who had distinguished himself in the Battle of Trafalgar, when in command of the Temeraire, of ninety-eight guns, engaging and taking a French and Spanish line-of-battle ship at the same time; and Captain Lord Cochrane, who was sent out by the Admiralty to take the command of some fire-ships, for the destruction of the enemy's force.

On the return of the fleet to Spithead from this successful enterprise, it was soon made public that an altercation or disagreement of an unpleasant nature had taken place between the senior officers, which was likely to lead to unpleasant consequences.

My Lord Gambier, it seems, was one of the first in command, who had sanctioned the distribution of religious tracts among the seamen of the fleet. Now, however wise and politic and morally proper this might seem to be, in all well-regulated minds, for the purpose of reforming the loose morals and dissolute habits of our sailor's, it is quite certain it did not always meet with the approbation or the necessary attention of captains and officers in command, who pretty well knew what sort of stuff their men were made of.

Innovations whether good or bad are generally introduced by the few, and always looked upon with a jaundiced eye by the many, and it is possible that the 
majority of the profession did not or would not appreciate the solicitude Lord Gambier had for the spiritual welfare of those "who go down to the sea in ships and occupy their business in the great waters." And experience tells us, 'tis a much easier task to dispel the doubts and establish the faith of a parish tea-party, than it is to evangelize a ship's company.

Nerertheless it must be admitted, either from this cause or some other, a great improvement has taken place in the general conduct of the men, both on shore and on board; and we have had undeniable proofs in the Crimea and in India, that a high religious feeling is not incompatible with personal bravery, any more than clerical instruction is with scientific acquirements in the art of war, although it may not require such religious ferrour in these times, as animated the soldiers of the commonwealth, to make a vigorous and murderous onslaught successful.

This, then, was the ground of dispute; and those two gallant officers held different and opposite opinions upon a practice that one had sanctioned and the other condemned.

The report then current was, that the rear-admiral, being very much annoyed at the instructions brought on board his ship by Lord Gambier's flag-lieutenant, that the command of the squadron destined for the destruction of the enemy was to be given to Lord Cochrane, an officer of a lower grade than himself, who had been sent out from England for that purpose, made use of an expletive not usually intended for polite ears, and attaching to it a prinomen generally ascribed to orer, or self-righteous people. 
This unfortunately was reported to his lordship, who on his arrival in port demanded a court-martial on his second in command, which accordingly assembled on board the Gladiator, the flag-ship of the harbour admiral : Sir Roger Curtis, then port admiral, sitting as president. The charge of disrespectful language to his superior officer, as commander-in-chief, being fully proved, this tried and gallant seaman, this brave and distinguished officer, who had served his country with so much honour from his youth up-was dismissed the service.

It gave infinite satisfaction to the Navy and to the country generally, when it was announced in the following Gazette that an order in council had restored Sir Eliab Harrey to his rank. Upon this Lord Gambier thought proper to insist upon a court-martial on himself. What the specific charges were I do not recollect, but I was present at the time and heard the sentence of the court pronounced, "Honourably aequitted," when the same flag officer who had presided at the late trial, on returning his lordship's sword, gave further proof of that amiable characteristic for which, through a long life and much service, he had been so celebrated.

Then came the trial of Lord Cochrane, arising out of the same affair, which terminated as did that upon Lord Gambier; and the excitement which so uncommon an occurrence had caused slowly and quietly evaporated.

About this time, from this and other causes, a number of naval officers would congregate in our streets, on their way to or from the Sallyport, where the different captains' gigs were constantly in attendance.

One morning five or six of them had gathered round VOL. I. 
the harbour admiral, "Little Billy Hargood," as the sailors called him. Now, this excellent officer had studied the rules of Hamilton More to greater advantage than he had those of Lindley Murray; consequently his rocabulary consisted chiefly of stereotyped phrases, the one most in use being, "I'll tell you what it is," with which he invariably addressed his subordinates. I unwittingly overheard the conversation between the Admiral and Sir Peter Parker, ${ }^{1}$ at that time in command of one of H.M. frigates, on the means he took to maintain discipline among his men, which he had heard through various channels.

Having listened with the greatest apparent attention to the Admiral's friendly admonition, which was replete with double negatives and other discordances, Sir Peter said, in turning away, and with the most perfect good understanding :-

"I tell you what it is, Admiral, I don't care nothing for none on 'em."

It was about five-and-twenty years after this, while pursuing my ordinary avocation, I was passing, at a moderate pace, by a large posting-house, about eleven miles from town, when I was hailed by the ostler to pull up. I immediately did so, and looking down on the oftside, saw a gentleman apparently in the vale of years, whose weather-beaten countenance I thought I had seen before. He asked me if I could take him to a certain

1 This gallant officer was killed in the last American war, when on shore with his men on some particular service. His handsome and manly features may be recognized in the hall of Greenwich Hospital. 
village through which I passed. I replied in the affirmative, and the box-seat being vacant, politely asked him if he would take it. He thanked me, and got up. We had not proceeded far before I was convinced, from some observations that fell in connection with the place of his destination, that I was not wrong in my conjecture.

My companion soon became affable and chatty, asking me many questions as to the names of the mansions we passed and their owners, the quality of the land, \&c. In answer to one of these, I purposely substituted Admiral for Sir. At this he looked at me with astonishment, and sharply demanded how I knew he was an admiral. I coolly replied that in my early life I had belonged to the same noble profession as himself; and though I had not had the honour of sailing with him, it was impossible for any one who knew anything of the service not to have known, or ever to have forgotten, so distinguished a member of it as Sir Eliab Harvey, saying which I raised my hat from my head.

"But when and where did you ever see me?" said the Admiral, impatiently.

"Often," I said, the spirit of former days rising in my throat, and almost choking me-"often; and the last time I saw you was on board the Gladiator, when you were tried by a court-martial, and-" I hesitated.

"And what, Sir?"

"And broke."

With unruffled features, he mildly asked-

"And what was I broke for, pray?" When I repeated the very words he had made use of, he laughed aloud; while I rejoined, that no one felt greater joy than I did 
when he was reinstated. He reached his destination after a two hours' ride, and at parting heartily shook me by the hand, saying he had had a very pleasant journey.

Another occurrence at this time was the embarkation of that crack regiment, the 10th Hussars, for the Peninsula. His Royal Highness George Prince of Tales, their Colonel, afterwards King George the Fourth, came down to Portsmouth to witness their departure. This caused no little stir in the old town. A review of the troops in the garrison took place on Southsea Common. The Prince was there on horseback, accompanied by an eccentric

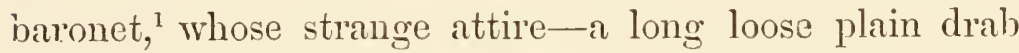
coat and a slouched hat, contrasted strongly with the tight Hussar jacket and the fur cap of his royal and rotund Patron. After the review the officers of the regiment gave a grand farewell dinner at one of the hotels to their distinguished Colonel, to which the principal officers of the garrison were invited, where my friend and I had the highly-prized privilege of seeing the first gentleman in the land sitting at the head of the table, gnawing a bone like a rustic.

It was not long after this that a most awful and melancholy accident occur'red, involving the death of five poor creatures. A detachment of some regiments of infantry had disembarked from Ireland, and had brought with them as much as eight or ten barrels of gunpowder, which were temporarily deposited on Point Beach. I was sitting having my hair cut in a hairdresser's shop at the bottom of the High Street, when a tremendous concussion

${ }^{1}$ Sir John Ladd. 
in the air, that seemed to shake the whole fabric, roused me from my seat, and, with the operation half performed, I rushed from the back of the house to the street, when I saw men and women running in crowds to the supposed scene of some great disaster. Some cried one thing, some another; but the loudest and most general cry was, that the Custom-house had been blown up. Joining the crowd, I presently ascertained this to be wrong, which relieved my panting heart not a little; for I had a near and dear friend there, whose wife was in the crowd, and who clung to me in her panic.

Having reassured her, and walked back with her a short distance, I hastened to the scene of destruction. The powder on the beach had by some means ignited. An Irishwoman, the wife of one of the soldiers who had disembarked with the detachment, had been sitting on one of the casks, smoking a pipe, which must have been the cause of this terrible explosion. The poor creature was never after seen alive. One other was blown over the houses, and dashed against the front of the Isle of Wight Sloop "Public," which was covered with blood and brains.

In all five, as I have said, suffered; but the most remarkable part of this sad calamity was, that the soldier who stood sentinel over the powder had his musket torn from his hold, and every button from the front of his jacket, by the force of the concussion, while he remained unhurt, though stupefied for a time-such, I believe, is the uncertain effect of gunpowder.

It is not a little singular that a similar catastrophe, though not from gunpowder, of a very recent date, should 
be equally as remarkable. The following is extracted from the Times of September 12th, 1859 :-

"Explosion on Bonrd the 'Great Eastern.'-The ruin here would have been an instructive sight for engineers to witness. It would be still better if medical men could inspect them, and solve the problem of how it can possibly have happened that men who stood round the case of the funnel when it exploded, and when tons of iron were torn up and cast about, were not only not killed on the spot, but scarcely one was unable to walk, and not one has sustained a fracture or dislocation."

Another occurrence which caused considerable excitement in the town, and which was attended with lamentable consequences, I cannot forbear relating, although at the risk of being termed a narrator of horror's.

Two French officers, who had broken their parole, hired a boat on Gosport beach, pretending they were going on board a vessel at Spithead. The waterman, who was well known to the inhabitants as a steady, hardworking man, had agreed for his fare, without the least suspicion of their character, or their dangerous enterprise. When they had reached Spithead, it is supposed he refused to proceed further at their desire; upon which, to gret possession of the boat, they rushed upon him with their knives, and after inflicting sereral wounds on his body, threw him overboard.

Fortunately the scuftle was not unobserved by one of the ships at anchor, whose commander immediately despatched a boat in chase, though too late to save the poor fellow's life; however, they succeeded in recapturing the wherry, and bringing the two miscreants to Portsmouth. 
They were taken before the magistrates, and by them committed to Winchester, for trial at the ensuing assizes, for murder. I need scarcely add they were condemned and executed.

The poor man's body was washed on shore a few days afterwards, and gave evident marks of the violent and cruel death he had met with. A handsome subscription was immediately entered into for his widow and orphans, by the principal inhabitants.

The untimely fate of the two Frenchmen caused no commiseration, and the justice of their sentence was never disputed. Doubtless they intended to cross the Channel in an open boat-a rash and daring deed of itself, and attended with considerable risk, worthy of men desirous of again joining their comrades and worshipping their idol; but they had put themselves out of the pale of international law-first by breaking their parole, and then by perpetrating a crime that made them amenable to the laws of humanity, and the country, of which their rictim was a peaceful citizen.

Some little time after this one of Buonaparte's ablest and most favourite generals attempted the same bold undertaking with success; of whom more in another chapter. 


\section{CHAPTER VI}

FRON YOUTH TO MANHOOD

Younger Sistei-Pleasant Gallop-Younger Brother-Pleasant Swim -Dreadful Disaster at Sea-A Naval Ball-Self-confidenceDomestic Sorrow-New Branch of an Old Acquaintance-Career of an Officer-A Distressed Mother, her Trials and her DeathPleasant Life-A Welcome Visitor-Sad Calamity-A TrioDuel-Pleasant Body Companion-The Comets of 1858 and of 1811-Description of-Astronomers.

The reader must not infer from the perusal of the preceding chapter, that I was inattentive to domestic occurrences, or that I was deficient in marking the progress, or rejoicing in the felicity, of any one member of our very happy family. My father then lived in a mansion or house he had built in the Forest-now occupied by one of our great naval commanders ${ }^{1}$ - where he enjoyed the society of his neighbour's and friends, and where, I need scarcely say, he kept a very good table, extending his hospitality to all around. Upon any extra display, I was generally sent for, as well to partake of some choice viands, as to participate in the hilarity of the company, or to be introduced to some of his numerous visitors. Upon one of these occasions I met with what might have been a serious accident.

1 Sir Charles Napier. 
The engaging manners, as well as sweet expression of countenance, of my second sister-then just growing into womanhood-had attracted the attention of a young man, who had come to settle in our parish; he was the son of a wealthy yeoman in another part of the county. After some little time he was accepted, and, upon the first interview of the parents - which, according to the rules of society, took place at the home of the betrothed-I was sent for from Portsmouth to meet them. I received the notification, at the same time, that the merits of a haunch of venison from the neighbouring park of Stanstead were to be discussed, as well as the matrimonal arrangements, and resolved not to be absent.

From some cause-I do not recollect what-I did not ride my own horse that day; and, not being then very particular what I did ride, I accepted the offer of a nicelooking, well-bred, little bay mare, that appeared to me to have all the qualifications of a perfect hackney. I did not know her, and my friend, to whom she belonged, did not make me acquainted with any of her misgivings. He had not had her many days, nor had he backed her many times; but I must think that he suspected a very peculiar propensity she possessed; and knowing that I was not in the habit of riding very slow, he showed no compunction nor fear of any consequence in lending her to me.

Accordingly I mounted, one hot summer's day; and, as I generally took about an hour-never more-to accomplish the ten miles-often did it in less-I did not leave till about two o'clock. I had not cleared the gates, and proceeded far on the road, before I found it was 
more a toil than a pleasure to ride such an animal; and the perspiration commenced running down my face in great profusion, till, arriving at the top of the hill approaching the entrance to the Forest, I thought I would give her her head, as my arms ached with holding her. After a few strides she got the bit in her mouth, and away she went at full speed. It was in vain for me to pull, and as I saw no danger, the road being perfectly straight, except what might be anticipated at the termination of her frolic, I stuck fast. Now, it was full three miles through the Forest to my father's house, and I faintly hoped she would become exhausted before reaching the village; but, as it happened, there were some men repairing a gulley, that conveyed the water under the road, just by the nine milestone. They had made an excavation not quite the width of the road, leaving, indeed, a way on each side. It was fruitless to pull her either to the right or left. On she went at the top of her speed-I shouting to the men when coming to the pit-and not being able to corer it, she jumped right in. The mare kept her legs, and I kept my seat; but, in jumping out of the pit, her head came in fearful collision with mine, and the concussion almost took away my senses. The excavators came to my assistance and held the mare till I had somewhat recovered myself; when, finding she was too much blown to make a similar effort, I got her, capering and dancing, and in much fear of another knock on the head, safe to my father's stables, about a mile further'; and when I dismounted I found myself quite enfeebled, and my head in great pain. Instead, therefore, of sitting down to enjoy the society of $m y$ 
father's new guests, and to make the acquaintance of $\mathrm{my}$ intended brother-in-law, or to partake of the smoking haunch, I was obliged to lie down. I did not recover till the next day, when the guests were all departed; and my father was extremely chagrined that I had been put upon so dangerous an animal, which he sent to its owner, with a not very pleasing message, by his groom. When I remonstrated with the owner for so unfriendly an act, seeing that I was quite free from injury he only smiled, though he was not a man as I thought to feel indifference when human life was in danger, and I had been on terms of the greatest intimacy with him. However, he quickly parted with the mare, and I had forgotten her, though not the very serious hazard she had put me to.

About three years after this I was at Portsclown Fair, where I was in the habit of meeting persons in the same business as myself. One of them, a particular friend from Southampton, and a most excellent judge of a horse, saw me in the act of purchasing a nice little bay mare. He walked away while $I$ mounted her with the intention of riding her home. Turning her head in that direction, she set off at full gallop down the hill, kicking and plunging all the way, but getting safe into the village at the foot of the hill. I dismounted, and, upon a little further' examination, recognized the identical animal that had before endangered my life. I had now become a married man; and being likely to have further claims upon me, did not choose to court danger; I therefore sent her home, and returned in a hired conveyance, not saying a word of what had happened.

In the morning a note arrived, bearing the Southampton 
post-mark, addressed to my wife, wherein the writer spoke of the danger her husband had witnessed. It also stated that he had found, upon inquiry, that the animal I had purchased was a most vicious and ungovernable brute; and she begged my wife to induce me to part with so dangerous a nag as soon as possible; this I did not hesitate to do.

Another movement in our domestic circle was the departure of one of my younger brothers. He, like me, had been sent to sea, and in one of our crack frigates ${ }^{1}$ had sailed up the Mediterranean, where his ship had joined the expedition up the Dardanelles, under Sir John T. Duckworth. It was on returning from thence he met with an accident that caused him to be sent home. Standing on the quarter-deck, the studding-sail haulyard-block fell from the maintop-gallant yardarm, and, striking him on the face, gave his jib-boom a twist that never righted; and the scar, also inflicted by the blow, he carried with him to an early grave.

In consequence of this he left the service for a time; and, being still very young, was sent to a celebrated naval academy at Gosport; but an offer being made by his old captain, ${ }^{2}$ who was son and brother to a peer, for him to sail in a small frigate, commanded by a young officer just posted, then fitting out at Portsmouth, I had to see him on board. Though we had already experienced the hardships and privations of a midshipman's berth, he was very loth to leave the comfort and comparative luxuries of oul happy home in exchange. Consequently, I had

1 The Sea Horse.

2 The Hon. Courtenay Boyle. 
some little difficulty in inducing him to join; but I eventually succeeded, and he soon became deroted to the service, and a great farourite with his captain and officers.

In the Bay of Naples this little frigate ${ }^{1}$ engaged and beat off one of superior weight, belonging to the French. My brother was standing by the side of the captain when the latter was struck by a cannon-ball on the shoulder, carrying away his epaulette; this my brother picked up, and, turning to his captain, saw that he was desperately wounded, and begged him to go below. This appeal was answered only by a frown-the first-lieutenant had been killed, and several of the other officers wounded; the decks were strewed with the dead and dying-so much so, that after the Frenchman had sheered off, a signal was made to a small brig in company for medical assistance.

This was considered one of the smartest engagements during the war, and upon the arrival of the captain with his craft at Spithead, minus his right arm, he was knighted; and after his recovery appointed to a larger frigate, into which my brother accompanied him, and served out his time.

After this he sailed in the Minden, seventy-four, when she took out Lord Moira, appointed GovernorGeneral of India, where he gained his promotion by being chiefly instrumental with his boat's crew in rendering assistance and saving the lives of the crew and passenger's on board the burning Elphinstone, East Indiaman, then lying at Point de Galle, homeward bound.

${ }^{1}$ The Cyane. 
The accident occurred by the steward's drawing some rum from a cask in the hold, which, through inadvertence, ignited. The principal part of her cargo consisting of saltpetre, it soon became beyond the power of the crew to subdue the flames; and, a signal of distress being made, boats were sent from the flag-ship. My brother in command of one proposed scuttling the ship, which was immediately adopted, and this fine 1,200-ton ship gradually went down, giving time for all on board, including many ladies, being safely sent away in the boats-my brother remaining till the last, when, jumping from the taffrail, he succeeded, after being some time in the water (for he was an excellent swimmer), in reaching the nearest boat.

For this act of disinterested zeal in preserving the lives of so many of his fellow-creatures, and the cool and deliberate courage he displayed, Sir Samuel Hood-than whom no admiral in command was ever more ready to distinguish or reward merit-granted him his commission as lieutenant.

Although I spent much of my leisure with the friend I have already named, I found time to entertain some of my old acquaintances in the Nary, among whom was one who was shortly after my interview with him lost in the Defence, seventy-four, of which ship he was lieutenant when she and the St. George, of ninety-eight guns, were lost in the Baltic, and all hands but one boat's crew unfortunately perished.

This was one of the most serious calamities that occurred during the war, and much blame was attributed to the ministers of the Naval department, for having kept such heavily armed ressels there so late in the season, 
when navigation in those boisterous seas becomes doubly perilous. But the only sacrifice made to the public voice, which was loud in its denouncement of such an error in judgment, if it was not an act of palpable incapacity, was the resignation of the first lord of the Admiralty. ${ }^{1}$

At this time my friend was a lieutenant of the Superl, seventy-four - commanded by Sir Richard G. Keats-just then returned from foreign service to be paid off. It being the time of the jubilee, when old King George entered the fifticth anniversary of his ascending the throne of these realms, the officers gave a grand ball and supper to others of their own rank then in port. I received an invitation from my old shipmate, and was, I believe, with a few exceptions from the dockyard officials, the only civilian there.

I had dined at my friend's house at an early hour, and had acquainted him with my engagements. Accordingly I left him early, and proceeded to the Point, intending to hire a wherry to take me up the harbour, where the Supert lay dismantled.

On my reaching the beach-which is generally lined with boats-to my great dismay, not a wherry was to be seen-nothing but a man-of-war's gig, with six men dressed alike in blue, apparently waiting for their captain; when, by sudden impulse, without halting, I walked directly down to the boat, stepped into her, and said to the coxswain, "Pull me on board the Superb."

Not a word more was spoken; each man at his thwart poised his oar in the air. Taking my seat and the yoke 1 The Hon. Charles Yorke. 
lines at the same time, the bowman, with his boat-hook, instantly shored off. Splash went the oar's in the water, and in a few minutes I was alongside.

"In bow-rowed of all," said I, as the well-manned boat glided silently to the foot of the stairs, wondering at my own impudence in daring to occupy the place of some skipper, who, for aught I knew, might be raging on the beach for his boat and crew.

Not a question was breathed during this short transit; and before ascending the ship's side, I silently rewarded the men's prompt obedience with a seven-shilling piece.

My friend received me at the port-hole of the main deck; and, ascending to the quarter, where he introduced me to his brother officer's, I found it hung round with flags and different devices, and canopied by a superb awning; the bulkheads of the captain's cabin had been removed to give ample length for the Contro dancequadrilles and waltzes not having yet been imported from the Continent.

The band of the Royal Marines attended; and after refreshments were lianded round, dancing commenced. The deck was crowded with gallant officers, young and old, rivalling each other in their attentions to the fairer sex, of which there was an ample attendance, some of whom could boast of superior attractions, and bewitching smiles seemed joyously to reward them for years of danger and toil.

Supper was served in the ward-room, to which part of the main-deck was added. Mirth, hilarity, and good humour perraded the seemingly entranced circle. Dancing recommenced; and I had the peculiar felicity, 
I remember, of leading down the belle of the party-a most splendid specimen of her sex, and also an excellent votary of Terpsichore, the wife of one of the officers. After keeping it up till morning, I returned on shore, in company with some whose acquaintance I had made, with many grateful thanks to my old friend and shipmate for my pleasurable enjoyment, of which I have a perfect recollection-not forgetting my own audacity, at the recital of which he laughed immoderately.

Poor Toby! ${ }^{1}$ thou hadst as true and honest a heart as ever warmed the breast of a British sailor, and as noble a spirit. Nearly fifty years have rolled away since the awful calamity that bereft their country of so many excellent officers, and of so many hundreds of fine fellows, lost to and bemoaned by their families and friends, occurred; and the sad remembrance of thy, alas! premature, death is more forcibly brought to my mind by the comparatively recent bereavement of a fine, handsome, high-spirited boy. Just of the age I then was, in the heyday of youth, hopeful and joyous, following the profession of his choice, he died in the camp before Sebastopol, of cholera; cut off in the blossom of his days, surrounded by stranger's -no one to whom he could impart his last farewell to those most dear to him-no one to lift his thoughts to the fountain of mercy-in the sound of cannon and in the midst of the turmoil of war was his spirit dismissed. May you both, unprepared as I fear you were, be presented at His judgment-seat by that great Mediator,

1 This young and active, but short-lived, officer was named Henry Philpot, and had no affinity to the celebrated original, except in name.

VOL. I. 
who can, though spotless Himself, see and commiserate our sinful condition.

It was about this time I renewed, or rather commenced, my acquaintance with the son of my old master, the D.D. I in the first chapter of this memoir alluded to, and brother-in-law to the most excellent gentleman who succeeded to the management of the Academy at Fulham, he having married the Doctor's daughter. I introduced myself to him by note, in which I spoke of my former knowledge of his family, and the respect I should ever entertain for them; and begged him to convince himself of my sincerity by partaking of my hospitality. He answered mine by a polite and complimentary note, in which he stated the pleasure he should have in acquiescing in my wishes.

Accordingly, he took the first opportunity of calling upon me. He was a fine, handsome young man, about six or seven years my senior in age, and his complexion and countenance gave sufficient evidence of his having already seen a good deal of service; and I had not known him long before his mamners convinced me that he had also seen the best society. Our occasional intercourse soon ripened into a close friendship; and upon his being appointed to the San Josef then lying at St. Helens, and bearing the flag of Sir Charles Cotton, I went on board that splendid first-rate man-of-war, and was received by his brother officers with all that politeness and good fellowship which naval officers at that time were fond of displaying to any civilian, more particularly when introduced by one of themselves.

Not long after this he was promoted to the rank of 
commander, and subsequently to that of post-captain. He commanded a frigate on the American station, in the last war with that republic." After acquitting himself most honourably in his profession, and distinguishing himself on several occasions, he retired at the end of the war, and lived in the neighbourhood of Plymouth. He has long since been summoned to his last account.

I frequently contemplate with retrospective pleasure my intimacy with this valuable member of the profession I was so partial to; and "through all the changing scenes of life" have cherished in my memory his friendship, and preserved to this day his correspondence. Through him and others I was introduced to many distinguished officers of both services. Indeed, my acquaintance became so general, that I may here boast of having entertained the heirs of earldoms and dukedoms at my table. ${ }^{2}$

Through him, too, I was introduced to a lady of title in London, ${ }^{3}$ at whose house he was a frequent visitor when there. Calling with him one morning, I remember her ladyship asked us both in so pressing, yet graceful manner, to stop and dine, that we could not refuse. Her features, regular and handsome, had not yet thrown off their matronly beauty, but a deep-set and habitual melancholy fixed a gloom upon a most expressive countenance, this gave a sombre charm to her otherwise engaging conversation. In her temporary absence I

${ }^{1}$ Captain Robert Rowley.

2 The late Earl of Egremont, and the present Duke of Northumberland.

3 Lady Pechell. 
made some observations to my friend, who, shaking his head said, "You will know all presently." And true enough I did; for her story took fast hold of my heart, and awakened all its sympathy. It was simply this, but told with such deep feeling and pathos-long sorrowing and disappointed hope being its chief burden-as only a mother could tell it, of whose acute and lengthened sufferings my pen would fail to give a description.

She had a son, "the only son of his mother, and she was a widow." This son entered the Nary at an early age ; had reached the rank of lieutenant; was a promising young officer, and bade fair to be an ormament to his profession, as well as a comfort to a fond and doting mother, of both of which, with melancholy pride, she produced handsome testimonials.

He was appointed to the Hamibal, 74, on the West India station, and in some operations against the enemy on the Spanish Main-as that part of the American continent immediately to the south of the Isthmus was then called-was taken prisoner with his boat's crew. No tidings had since been heard of him. When the aggressive policy of the French Emperor against the Spanish Monarchy, followed by his invasion of the Peninsula, caused the Spaniards to throw off the French yoke, and make a treaty of alliance with us, it raised her hopes to the highest pitch; and she had been vainly expecting, upon every arriral from that part of the world, to embrace her son, or at least to hear some good tidings of him. But alas! year after year had flown away, and nothing authentic could be gathered from either officers or seamen who had previously known him, as to his ultimate fate. 
Once it was said he had been observed at work in the mines, to which it was the custom of the Spanish Government to send all persons suspected as spies; at another he was seen in the streets of Carthagena, ignominiously chained with others, under charge of an altado. But none of these reports led to any satisfactory result; and the contimued representations of our Gorernment to the Spanish authorities were of no avail. Living in this dreadful state of suspense, not willing to believe that her son must have fallen a rictim to the climate, she caught at the faintest shadow of hope at his being yet alive. Knowing from my friend my residence at the principal sea-port of the kingdom, she vainly thought I could be of considerable service to her ; and as I deeply sympathized with her, I readily assented to be at her command. I therefore never went to London without seeing her, and for some time corresponded with her on this melancholy subject. When the Hannibal arrived from the station to be paid off, I went on board, and took down the deposition ${ }^{1}$ of one of the men, who declared he had seen the lieutenant alive in the mines; but this, like other reports, could never be substantiated; and not long after, this accomplished lady went to her grave, a sorrowful and broken-hearted mother.

Thus, then, reader, did my life pass from youth to manhood-my time partly occupied in attending to a business-that not having any appearance of business, or requiring confinement, was itself a pleasure-and partly on those exciting and not irrational enjoyments that cir-

1 This deposition, attested by the senior officer of the Hannibal, is still in my possession. 
cumstances justified and indulgent parents did not disapprove. Although I had no establishment of my own, I exercised the authority of a master over every grade of dependents, both in-doors and out; indeed, I occupied such a position that one day my old captain, when he called to express his hearty congratulations at the change of my appearance, assured me that he envied me the fairness of my prospects.

My father and his fimily living almost entirely in the country, a distance of ten miles, I generally spent my Sundays with them, accompanied by some friend or other, whom I drove over, and to whom my father, I knew, would glidly extend his hospitality. Upon one occasion, I remember, I felt delighted in introducing to our family circle one of my best and kindest shipmatesthe lieutenant officer of my watch ${ }^{1}$ I have before spoken of, and to whom, on his return from India, I felt proud in offering any civility in my power, for the very kind but officer-like treatment I had ever received at his hands. His fascinating manners and conversation, at all times interesting and agreeable, made him a great farourite with all.

It was not long after this that a calamity befell him, and for some considerable time removed him from our locality. He had married a lady of excellent family and good personal and mental accomplishments. On being appointed to the Plantagenet, 74, then lying in dock at Portsmouth, he took his bride on board to see the ship, when, looking down the hatchway, terrible to relate, she was seized with a sudden giddiness, fell the whole depth

1 Lieutenant Samuel Greenway. 
of the ressel from the quarter-deck to the keel, and was killed on the spot.

It may be possible to conceive, but not possible to describe, the revulsion such a sudden and awful catastrophe would cause in a heart so sensitively alive to all the tender passions and sympathies of our nature as his. The object of a long-cherished affection, which absence had only rendered more dear, was in a moment snatched away-the vows made with all the ardour of youthful love, and faithfully kept, were scarcely consummated when death dashed the reward of his constancy to the ground, and with it all his hopes of happiness in this world.

This melancholy accident caused a great sensation through the fleet, as well as in the town, and for a time deprived the lieutenant of his senses; and though he was eventually restored, I for one thought he was never the same man afterwards. He was constantly employed, and distinguished himself as a brave and skilful officer, when first lieutenant of the Revolutionnaire, forty-four grun frigate, in Basque Roads, under peculiar circumstances.

The Revolutionnaire was the inshore look-out frigate, and the captain had brought her to anchor almost within gun-shot of the French squadron, while he in the barge went to make a further reconnoissance. This was early in the morning; when, some few hour's later, the boat was observed pulling towards the ship, with three or four others of the enemy in pursuit, and a large ship, under sail, bearing down and firing her bow-chasers.

It was evident that the frigate was in imminent danger 
of being taken if she remained at anchor, and of the captain's being cut off in his boat if she did not. In this fix the first lieutenant, knowing the sailing qualities of his ship, as well as the quality of his men, determined not to sacrifice his captain; he therefore held hard, manned tacks and sheets, jib and staysail hawl-yards, frc., a man at the hawse-hole with an axe, and everything ready alow and aloft for a start.

All kept their eyes most anxiously on the barge, which, though hotly pursued, was nearing the ship fast, while the shot from the enemy's line-of-battle ship flew through the rigging. All was silent on board-not a gum was fired; but directly the bowman in the barge hooked on, and the captain had hold of the side-ropes, the word was given-the cable was cut, the sails were sheeted home, and the wind being off shore, she turned on her heel, and gave the Frenchman what the sailors call leg-bail. All this was the work of a minute, and, as related to me by an officer on board, it had more the appearance of magic than the effect of discipline.

The captain, on his reaching the quarter-deck, thanked his first lieutenant for his friendship, as well as the cool and deliberate conduct he had displayed; and this extraordinary feat was spoken of throughout the Navy for years.

About this time our family circle was enlivened by the wedding of my second sister, upon which occasion I joined the new-married couple in London (my first trip there since my return from sea), and in their company visited the theatres and all the principal places of public resort in the great metropolis-not forgetting the 
live lions in the Tower, and the dead ones in Westminster Abbey.

In the autumn, when on a visit to one of her husband's relations, near Winchester, we attended 'a grand ball at St. John's House, in that city, given in honour of his Majesty's having completed the fiftieth year of his reign. Some of the military, in their full uniform, were there, and a great many of the aristocracy of the county, among the latter the heir of Dogmersfield and his youthful bride, who were quite the attraction of the evening, for a more magnificent specimen of either sex never was seen. How short-lived their happinęss history has told-how blighted his fair prospects the severe moralist would record without a tear-while the more compassionate would tremble at the frailties of our nature.

It must have been shortly afterwards that a famous foot-pad, named Pitt, though better known and dreaded as "the man with the short gun," was executed in this city for highway robbery; and on my father's going to see him in jail, at the request of the magistrates, he confessed that he had endeavoured to stop him several times on Horndean Downs, lying in wait for him in one of the clumps of firs planted at intervals near the road; but my father had always ridden too fast for him, and being so often baffled, he at last fired at him, but without effect. My father was generally late in returning from Petersfield, and that evening had $£ 800$ about him.

As a singular occurrence of this period of my life, I must relate one that arose from a practice then very much in vogue, but which every well-ordered mind gladly sees is becoming obsolete. I relate it principally to show upon 
what slight grounds, and for what unworthy purposes, two immortal souls may be put in jeopardy, and the laws of man and the commandments of God broken and despised.

Among the officers of my acquaintance in the garrison was a captain of a militia regiment, who had long been stationed at Portsmouth, of which he was also adjutant. He was a tall, fine, soldierlike looking man, and withal a thorough-bred sportsman. I had met him fiequently in the field, particularly with two other friends of mine in the country, with whom he was at all times glad to associate, as they were all three farourite sons of Nimrod, and emulated each other in all the accomplishments of that celebrated hunter of the field. Indeed, such a trio, with such real love for, and thorough knowledge of, field sports, in every branch, and all so similarly endowed by nature for their enjoyments, it has not been my fortune to meet with since.

With one, who was near my own age, I was on closer terms of intimacy than I was with the others. He had an elder and an only brother, who was a beneficed clergyman in Northamptonshire. Living so wide apart, and their pursuits being as widely different, the brothers did not often meet, though there was no want of affection on either side.

On one of these rare occurrences, when stopping at the vicarage, the elder brother, as became his profession, took upon him after dinner to expatiate upon the necessity of every good member of society making himself thoroughly acquainted with the Bible, adding that he feared, from what he had heard of the sporting propensities of his 
brother, that he had not given up much of his time to the perusal of that holy book. The younger one sat silent and demure, seemingly impressed with the importance of the subject, as he was seriously attentive to his brother's admonitions.

When he had concluded, my friend sat some little time cogitating on the discourse he had just heard, when the parson rallied him, hoping he would not take what he had said unkind, or even deem it ill-timed.

"Not at all, brother," he said, "not at all. I was only thinking, when David went partridge-shooting, whether he had pointers or setters, and whether he used the detonaters, or common flint and steel."

The other, drawing himself up, said,-

"I did not expect, sir, you would have made a mock of what I have said."

"Neither do I, sir," retorted the brother"; "I merely put a plain question, and you would oblige me by giving me as plain an answer."

"I was not aware, George," observed the parson, altering his tone, "that David ever went partridge-shooting."

"Then turn to your Bible, brother, and in the twentysixth chapter of the first Book of Samuel, and the twentieth rerse, you will find that he did."

The evidence was conclusive in more ways than one, and the subject was seldom, if ever, renerwed.

The manners of the soldier were the least polished of the three, but at the same time always unassuming and agreeable. Jovial either at the mess or the social board, his conversation, when on field-sports, or anything relating thereto, was highly entertaining. 
I was standing under" the "George" gateway, in the High Street, having just then returned with him from a run with the Hambledon hounds, early in the evening, though it was dark, and conversing on the occurrences of the day, when a female, in passing, stepped on one side, and said, calling him by name,-

"Surely you will not see a female insulted?"

Advancing a step or two into the street, he-I supposed inadvertently-said, —

"I am sure no gentleman would persist in insulting a female."

The word was sufficient, for an officer in the undress uniform of the Royal Artillery immediately addressed him, and, after a very few words, put his card into my friend's hand, and, saying that he expected to hear from him as soon as possible, turned on his heel, and walked away.

My friend, who did not seem at all flushed with this short but significant interview, which scarcely lasted a minute, took hold of my arm, and saying, "This is a pretty piece of business," walked with me to my house, about thirty yards higher up the street. Seating himself, very coolly he added,--

"You must go out with me."

I looked at him with astonishment, and told him such a thing was out of the question; but he persisted, and would take no denial, on the threat of his cutting me. I tried to convince him it would be more in unison with general usage on such occasions to seek the aid of a brother officer than a civilian like myself. To this he would not listen, as his colonel was not the 
man to sanction the practice; but on my naming the officer of Marines whom we both knew, and who happened to pass on horseback while we were under the gateway, a note was instantly despatched to him. He then asked me to lend him or get him a pair of pistols; this I also refused, but told him where they could be procured. They were sent for and approved, and on the arrival of his friend they, much to my satisfaction, wishing me a good night, walked away together.

I felt it then to be my duty as a civilian to give information of the intention of the two interested parties to the magistrates, which I could easily have done, and that meeting would have been prevented. But how should I have stood with my naval and military acquaintance? They knowing that I, and I only, as a disinterested party, was in the secret, I could not escape detection; and my pride would not allow me to forego the honour of associating with them. Moreover, instigated by curiosity, I had a mind to see the issue. I therefore in the morning saddled my horse before daylight, and in less than halfan-hour reached the spot where the two combatants had already arrived, with their seconds, in two post-chaisesthe artillery officer accompanied by a surgeon. I dismounted, and, fastening my horse to a stake in a hedge, had a view of the whole affair.

At the first shot my friend's bullet grazed his adversary's cheek, taking with it his whisker. Not satisfied with this, he insisted upon another shot, when he received my friend's charge in his side, and fell, his opponent escaping unhurt. Upon approaching him, he did not 
speak, and his second, taking up the pistol, insisted upon revenging the death of his principal, or sharing his fate; but to this my friend replied, he had no quarrel with him, and having fully satisfied the laws of honour, he should decline his invitation; then he and his friend, supposing the wound to be mortal, thought it best to absent themselves, and, stepping into their chaise, the postillion, who had orders to proceed across the country to a post-town, on another road to London, mounted and rode off.

The wounded officer was remored from the field, and was for more than a month in a precarious state; the ball, having lodged in the spine, could not be extracted. However, he got well, shortly afterwards accompanied his battalion to the Peninsula, and served during the remainder of the war with the ball in his back.

My friend, after a month's absence, returned to his regiment, and the whole affair was soon forgotten.

I shall conclude this long chapter with recording a description of the great comet that appeared about this time-that is, in the year 1811-which the comet of 1858 brought fresh to my mind.

Living then at Portsmouth, I used frequently-indeed most nights during the months of its appearance, that is, September and October-to walk on the Platform, now called the Saluting Battery, in company with the friend I have before spoken of, to view this strange and brilliant object. I have a perfect recollection of its appearance and position in the hearens, though I cannot state in what constellation it was first seen. It was about 30 degrees above the horizon at nine o'clock, and from where 
we viewed it, was directly orer the Isle of Wight; consequently it would be a little to the westward of south. I cannot better describe it than by comparing it in shape and size to a large rod. The small end denoting the nucleus or star-which was much larger than the late comet, of a deeper hue, and at a certain distance seemed confined by a band, beyond which it spread out in rays of fiery red. It seemed to lay, as it were, directly parallel with the horizon, and had not anything like the length of tail that was so remarkable in its successor, for its beautiful plume-like and far-extending luminous appearance. Still, it lit up that part of the heavens it traversed, and obscured by its brilliancy a number of stars of every degree.

Its aspect to the vulgar, who look upon such phenomena with indiscriminate wonder, was more awful than auspicious, and elicited in many, apprehensions that were allayed only by its gradual disappearance. To the astronomer it was what the last has been-a great prize; and his science was carried to its utmost extent in calculating the orbit and time of return, the diameter and length of tail of the heavenly body, the distance from the sun and our earth, as well as the rate of travelling and destination of this single luminary; and, by a happy conjunction, it also enabled him to establish a further proof of the raporous elements of those erratic messengers-as Arcturus, a star of the first magnitude, shone with increased brilliancy through its nucleus.

To the speculative philosopher it would display the omniscience and the will of the great Creator, in setting bounds to the human understanding, and drawing the 
line of demarcation between scientific proof and dubitable conjecture; sufficient to develop the infinite power and wisdom of the great Architect of the univer'se,-and to denote the feebleness and the failure of our faculties when attempting to penetrate beyond those limits to which His immutable law has confined them.

Thus it is that human intellect of the highest order, ever prone to apply the rules of science to things beyond its reach, becomes lost in perplexity and confounded by a sense of its own incapacity. And thus it ever will be, till that great change takes place, when the wonders and the secrets, as well as the glory, of the Deity, shall be made manifest to all those who have been true believer's in, and faithful followers of, His holy Word. Therefore, as to a knowledge of animal life in either Venus or Jupiter, or of the purpose of the Almighty in creating spheres at such immeasurable distance from our planet, and solving the problem of the plurality of worlds, the ignorant peasant is on a par with the Astronomer Royal, or the first scholar in Europe.

1 When the subject lies so far beyond our reach, the difference between the highest and the lowest of human understandings may indeed be calculated as infinitely small.-Giввок. 


\section{CHAPTER VII}

\section{COURTSHIP}

The New Forest-The Confines of Dorset-A Country TownShooting-Lord Chancellor Eldon-Encombe-Sir Walter Raleigh - Smoking - Lulworth - Corfe Castle - Edward the Martyr-King John-Lady Bankes-The Heroes of the Parliamentary Army-Christian Preachers-Education-An Original Sect-A Legend-The Isle of Wight-The Royal Cockpit-A Joke-The Duke of Deronshire-Two Foreign Princes-A Prince of Coach Proprietors-Friend in Need-A False StepAn Establishment-Wedding-Breach of the Law-Mr. Justice Burroughs-Soberton Downs-An Israelite Sportsman-A Bet -A Fracas-Lawsuit_Judge Gazelee-A Dispute on a Point of Law-Mr. Serjeant Pell.

Is the preceding chapters the reader will observe that I brought the history of my life down nearly to the close of an epoch when, though the mind is generally occupied in daily business or present enjoyment, the heart is left open to impressions that turn the stream of thought to the anticipation of a more durable and a more rational felicity.

In seeking, or perhaps in finding without seeking, an object whose qualifications would lead to the realization of a very pleasing vision, I was induced seriously to consider that alteration in my condition for which I had manifested (chiefly from the example of my associates) a strong predisposition. This object had fixed my attention

VOL. I. 
for some little time; how, or in what way, or under what circumstances, my heart received that impression, it matters not now to relate-let it suffice to say that it was commenced in melancholy, and so terminated; but having entertained an idea, I was determined to carry it out, with indefatigable persererance, to its natural result.

This caused me many a long, but always pleasant, though solitary ride, along the glarles of the New Forest, a locality full of the most picturesque landscapes, and rife with historical events. Here I belield the smoke curling from the thatched roof of the woodman's cottage, with its garden and nicely trimmed fence, and a solitary cow contentedly ruminating on the luxuriant lawn before it; while at irregular distances stood in their perfection some of the best specimens of the majestic oak:- there to the right of the lone public, called Stony Cross, were the remains of the tree from which glanced the arrow that lay the second William dead;-while I was admiring one or recalling the other, came bounding by, a herd of the most graceful animals in the creation, all tending to give additional zest to the pleasing romance that was uppermost in my mind.

Well mounted, I passed on, I remember, through the small but clean and pleasant town of Ringwood; and, pursuing my journey westward, entered upon those dreary and seemingly interminable heaths that connect the two counties, till I arrived at an old decayed town in Dorsetshire.

In my first journey I was quite a stranger to the country for the last twenty miles, and as I mused over the great extent of black uncultivated land which met 
my eye on every side, producing nothing but stunted fern, that a few half-starved sheep were browsing on, I could but contrast it with the sunny downs of Hampshire and the wood-crowned hills of Surrey; the former affording pasture to innumerable flocks of that valuable animal, the latter testifying to the good effects arising from the judicious employment of capital and labour.

It being dark on my arrival at the principal inn, the instructions I gave the ostler as to taking care of the good horse that had brought me more than sixty miles that day, elicited a few remarks, which I afterwards learned from some of the townspeople who had followed me into the inn yard, or issued from the house on seeing the arrival of a stranger.

"I wonders who he be?" said one.

"What be he come vor"?" said another" whilst a third, who pretended to be more knowing than the others, observed,-

"I dun know who he be, or what he be come vor, but he have got a good oss, and knows how to take care on un."

Inquiling my way to the house I wanted, I was easily directed, and, knocking at the door, met with a hearty and kind reception from all the members of the family, which then consisted of but three-who were attired in mourning for the recent loss of a beautiful and amiable elder daughter in the bloom of life. Retiring early to bed and sleeping sound, I did not wake till morning, when, my room being in front of the house, my senses were aroused by the strangest cries, which to me were quite unintelligible. 
"Marn-tée," from shrill and aged female voices, was the most prevalent, and which I was duly informed at the breakfast-table was intended to convey the morning': salutation. Upon rising, the father of my intended bride, a fine handsome man, somewhat under sixty years of age, with a countenance blooming with health and expressive of good-humour, proposing a walk, we sallied out to take a view of, to me, this interesting old town.

Its decayed and overthrown walls, erected for defence against the common enemy, are now the site of productive gardens, set aside by the owner of the soil for the accommodation of the inhabitants; and they give evidence of a much larger area and a more numerous population, while the ivy-grown towers and walls of dilapidated churches aftord as ample testimony of the ancient, thougl more remote and rude magnificence of this important possession of our Saxon ancestor's.

Situated at the head of the estuary that opens its way through the harbour of Poole into the ocean, it was not difficult of access to those enterprising and bold pirates that so continually harassed our consts ; and their frequent visits to this town and neighbourhood, exemplified by many large barrows, would give reason to suppose that not only was this part of our island much more thickly populated, but that the soil was of a more productive nature than it is at present; for if it then bore the same appearance it now does, there was little to be devastated, and nothing to carry away; therefore nothing to invite the presence of the roving Viking, or to reward the courage of a conquering army or a lival nation.

Many were the recognitions that passed between the 
companion of my walk and the townspeople we met; and I could but smile at the rude dialect and primitive manners and appearance of the generality of the inhabitants of this isolated district-a district, devoid as it was of that first step towards civilization, a stage-coach : for it only communicated with the world by a boy, the sound of whose horn immediately reminded me of Cowper's animated description :-

" Hark, 'tis the twanging horn o'er yonder bridge!

He comes, the herald of a noisy world,

With spattered boots, strapt waist, and frozen locks, News from all nations lumbering at his back."

During my first risit, which was necessarily short, on account of my father's business at home, I was introduced to some of the elite of the town, which was the means of my becoming acquainted with a few respectable families in the Isle of Purbeck, as that part of Dorsetshire is called that extends from the river Frome to the sea. Their hospitality I frequently enjoyed, and in the shooting season I was always a welcome visitor.

I remember on one occasion shooting with a gentleman whose land joined on to the Encombe estate, the property of the late Lord Chancellor Eldon, who had then recently purchased it from the family of Mr. Moreton Pitt, at which retired spot he always spent the summer racation. Walking towards the plantation that set bounds to my companion's beat, I observed at a short distance a portlylooking gentleman, with a gun in his hand, a brace of dogs at his feet, and an attendant close by. At the moment a fine cock pheasant got up, which the gentleman fired at, but missed. The bird flying towards the 
plantation crossed our path, when, the temptation being too strong to resist, I levelled my Manton, and the bird dropped. Upon my friend's informing me that the stranger was Lord Eldon, I ran and picked up the bird, and, with a slight obeisance, begged his Lordship's acceptance of it.

"Oh, no, sir," said his Lordship_-"keep the bird, I pray ; 'twas a fair shot, and you are entitled to it."

So saying, he turned to my friend, and conversed with him on the growth of Swerle turnips, which had only recently been cultivated in that district. He then went in at the white gate that leads down to the mansion, wishing us good morning.

In the following spring or summer, I revisited this spot with a few friends of both sexes, in a carriage, and entering by the same white gate, I found it required some little experience and care, as we drove down the steep declivity, planted on either side with thriving trees of every variety, that completely enveloped the mansion, from whose chimneys no smoke issued to tell of its whereabouts, so that we did not discern it till we were fairly in the stable-yard. Leaving our carriage and horses to the care of an attendant, after viewing the house, which was an unpretending specimen in the Grecian style of architecture, very meanly furnished, we walked through the grounds. 'They lay in a deep ravine, formed by two hills or lieights-one of which is called St. Alban's Head, properly St. Adhelm's-and are terminated by a slight iron pallisade, from base to base, which the tide constantly washes, and through which we had a full riew of the British Chamnel. 
It is indeed a most secluded spot, and seemed designed for the habitation of a recluse, or selected for the repose and relaxation of one whose energies were required and deroted to the fulfilling the duties of the highest office in the state. Before we left, and while enjoying the social conversation that a beautiful day and pleasant company promoted, I observed with what apparent ease a French privateer might cross the Channel, land a boat's crew, and carry off the Lord Chancellor, great seal and all, from this solitary and defenceless spot.

Upon another shooting excursion in an opposite direction, where in a wild and open country the sportsman has some little cifficulty to find and follow his game, I came upon the louse where that great but ill-fated genius, Sir Walter Raleigh, first introduced the custom of smoking-now so prevalent among all classes. It was a long, low building, with a thatched roof. At the time I was there it was a public, as lonely as Colman's "Red Cow" on Muckslush Heath. Here my companion and I repaired for refreshment, which we partook of in the room where that celebrated scholar, courtier, warrior, historian, and philosopher, indulged in his new-discovered luxury, which he had learned from the red men of Virginia. A young rustic, as tradition goes, perceiving the smoke issuing from his mouth and nostrils, threw the contents of a flagon orer him to extinguish, as he ignorantly thought, the fire that was about to consume him.

Another took me to the neighbourhood of Lulworth, and its castle-the seat of the Roman Catholic family of the Welds-is as conspicuous for its modern architecture 
as it is for being the presumed birth-place of one whose name figures prominently in the biography of the last Prince of Wales. ${ }^{1}$

But the object that chiefly attracts the stranger in these parts, to which I paid more than one visit, is the romantic and extensive ruins of Corfe Castle, so celebrated in different epochs of our history. Built on a knoll between two stupendous hills, it formed a strong fortress before the invention of gunpowder, commanding the passage from the coast to the interior, and, from the great extent of the ruins, must have been able to contain a numerous garrison, and to afford refuge to the inhabitants of the neighbouring towns and villages, when flying from the ravages of the piratical Danes.

It was some time the resilence of our Saxon kings, and the scene of many a barbarous deed. It was here the unhappy Edward met with his untimely fate from the hands of his cruel step-mother, Elfrida: and the arch of the gate is still standing. on the sides of which lovers now inscribe their names. The miscreant John, too, here perpetrated one of his most cruel and diabolical massacres. ${ }^{2}$

In later days, cluring the progress of the civil war, it was a fortress of considerable importance, and was held for the King by Lady Bankes, who has rendered her name illustrious by the prolonged and successful defence she made against the besieger's under Sir William Erle; but on a second siege it was delivered up to the Parlia-

1 Mrs. Fitzherbert.

2 Twenty-two Poicterin nobles were starved to death in one of the Aungeons. 
mentary forces by the treachery of one of the King's officers.

The ruins, which are not to be surpassed by any in the kingdom for their romantic and picturesque appearance, are remarkable also for the singular position in which the means used for their creation have left different and distinct portions of their massive walls; one of which is overgrown with the largest and most luxuriant piece of ivy ever seen. They will amply repay the visitur. for any trouble or expense he may be at for his easy access to them-a railroad having now for some considerable time penetrated to within four miles of this hitherto secluded portion of the Queen's dominions.

The glory of the demolition of this once magnificent pile of Saxon architecture is due to the malignant spirit that seems to have animated the Parliament as well ats their army. Had their deeds been confined to working out the civil and religious liberties of their country, and destroying every semblance of oppression and tyranny, posterity would not have had to lament the sweeping destruction of many exquisite works of art that adorned our cathedrals and churches; effected by those redoubtable heroes, whose pious zeal converted their renerable aisles into stables, and otherwise desecrated the splendid edifices, from which ruin they have never recorered. While their pulpits, which had boasted of the pure doctrine and simple eloquence of the followers and admirers of a Parker or a Whitgift, were usurped by an ignorant preacher, with lank hair and doleful risage, bellowing, in a strong nasal twang, a jargon of confused 
and almost unintelligible phrases, which his deluded congregation mistook for divine inspiration; and thus became the means of substituting cant and hypocrisy for true religion, and a miserable and morose fanaticism for the kindly duties presented by the first teachers of the gospel.

The casual observer must think it a privilege to live in an age when such absurdities are exploded, and the common sense of the people seems to have set bounds to the extravagances of self-constituted preacher's; and when those only are listened to of any sect who have at least the pretensions of education and preparation for the office of ministers of Christ.

He would probably overlook that weakness in our nature that is now so conspicuous in the crowd who hang upon the originality of style, tinged by buffoonery; and eccentric declamation, sometimes approaching blasphemy, practised by a loud and roluble, but rain and presumptuous, popular preacher.

The enthusiast would arow, and the sceptic would admit, that men of less pretensions, and under less farourable circumstances. have, at different epochs in the history of our Church, founded sects, and "led away divers people having itching ears"; while the vulgar of every class would raise a tabernacle to his honour, and rank him with many other's whose names have done no credit to the creed he professes to expound. But the sincere believer would fain hope that the effervescence created by the novelty of his powerful preaching will gradually subside, and that the dignity of human reason and the sanctity of pirre religion may be vindicated by the con- 
victions and examples of the more sober-thinking part of the community.

In the meantime, it may be asked, when will our countrymen cease to be worshippers of this too palpable spirit of a charlatan? Will education ever secure the mind of the multitude from the inroads or allurements of fashion and of folly, and prevent the senses being captivated by the display of gross dramatic misrepresentations, with an unhallowed colloquy, assisted only by stentorian lungs and not rery graceful action?

The preaching of Irving, and the delusive mockery of the unknown tongues, may live in the recollection of some of my reader's, who will not fail to compare, when recognizing a similar attraction, the merits of these two religious stars. Both possessed original conceptions, or, rather, misconceptions, but the one displayed a manly eloquence, in which attainments of the highest order shone forth, and maintained a dignified attitude and graceful delivery throughout; while the other, in order to enforce his doctrine, at all times acceptable to the ignorant, and to please the fancies of his congregation, is obliged, in the absence of genius, to call in the aid of the mountebank.

It is with far different feelings we review the vestiges of the infatuation of former days, in the peculiar dress and formal manner's of one particular sect, who are not on the increase, nor do they by any of the arts of proselytism seek to propagate their singular doctrines; indeed, among the principal families of this wealthy and hitherto innocuous sect, those outward marks of observance are falling into desuetude; while they themselves aim at 
a much higher distinction, by becoming the practical dispensers of a pure and more useful philanthropy; thus exhibiting Christianity in its brightest phase, and putting to shame the rapid denunciations of the idol of the vulgar.

If I might be allowed to dwell upon the interesting objects this part of our island contains, I could tell of a drive to Abbey Milton, then the splendid seat of the Damer or Dorchester family, since, I believe, passed to some wealthy merchant-of Bryanston, the equally magnificent mansion and domain of $\mathrm{Mr}$., now Lord Portman-of Clarborough, then the seat of Mr. Drax Grosvenor, remarkable chiefly, in an historical view, for its being the spot where the plan of that glorious revolutiun which drove James from the throne of these realms was concocted : this is duly recorded over the door of a small building in the grounds ${ }^{1}$ - of Woodbury Hill, from whence the view orer the surrounding country is most extensive-and of the small town of Swanage, with its long, narrow, single street, terminating in a parapet or battery, mounting about nine guns, commanding the entrance to the Needles; as well as a fine riew of the beautiful island, now the resort of so many fashionable

1 The following is the inscription :- " Under this roof, in the year 1686 , a set of patriotic gentlemen of this place concocted the plan of the glorious revolution, with the immortal King William, to whom we owe our deliverance from popery and slavery-the expulsion of the tyrant race of the Stuarts - the restitution of our libertiessecurity of our property, and the establishment of our national honour and wealth. Englishmen, remember this era, and consider that your liberty, obtained by the virtue of your ancestors, must be maintained by yourselres!" 
visitors, and the frequent residence of the sorereign of these kingdoms, and her youthful family, on whose welfare the hopes of the nation are fixed: and where, among the hospitable yeomen, I have spent many a rollicking day. One of my friends kept an excellent pack of harriers with which to entertain his friends in and out of the island, and it did not require a father's last will to enforce this as an obligation; another was famer for a superior breed of game-cocks, called from their plumage the yellow-legged duck-wing, and annually invited some few amateurs to witness an exhibition of their natural propensity, and afterwards to partake of his unbounded and uproarious hospitality.

- But those dars are past, and with them such pastimes are fast dying out. I rejoice, with others, at the more refined amusements that have taken their place.

Yet it was one that princes and nobles participated in. I may mention that, on the occasion of the visit of the two grand dukes. brothers of the Emperor Alexander, to this country a few year's later, an exhibition of this description took place at the Royal Cockpit, Westminster, for the express purpose of instructing their imperial highnesses in the amusements that were considered characteristic of us Islanders. The admission was by tickets, distributed to the member's of the aristocracy then in town, and to some favoured indiriduals, friends of Mr. Jackson. of pugilistic celebrity, who was appointed to superintend the arrangements. I was in London at the time, without any thought of obtaining a ticket, but just on the day I accidentally met with a well-known winemerchant. who was generally put on. as the term is, on 
such occasions, being on the best of terms with Mr. Jackson. He asked me to dine with him, stating that he should have to leare me early, as he had to attend at the pit at Westminster. Not being better engaged, I accepted his invitation. At the table he rentured an apology, told me the nature of his engagement, and expressed regret that he could not introduce me, tickets not being obtainable for any money, nor even by any farour-which did not fail to strengthen my desire of witnessing the scene.

Accordingly, rising after wine, he would have taken leave of me at his door, but I, saying that I was going down l'arliament Street, we walked together. At the corner of Bridge Street he would have left me, but I expressed a desire to see him to the entrance, for I did not know where this celebrated pit was. I did so, and taking leave of me, he went in. Instead of returning, I suddenly resolved upon following him. He was a fullsized man, both in height and width, and occupied the whole passage which led to where the person who was appointed to take the tickets, sat. I observed iny friend give him an authoritative nod, and following immediately in his wake, unknown to him, did the same, and was allowed to pass without a question.

On entering the arena, I turned in an opposite direction to that which my friend took, and got an excellent place, both for a view of what was going on as well as of the two foreign princes, who stood on each side the Duke of Deronshire; his Grace was conspicuous for the silver trumpet he constantly applied to his ear, being, as I supposed, rery deaf. The fine figures of both the 
illustrious visitors attracted great attention, but chiefly the form and features of the elder, who afterwards became the Emperor Nicholas.

My friend, who stood near them, in catching my eye, looked unutterable astonishment, and came round and asked me what means I had used to gain admittancesuspecting bribery, as I supposed. When I had told him the very easy way by which I had obtained my object, he could scarcely believe me. but gare me credit for tact and self-possession.

To resume the thread of my narrative: there was nothing now wanting to the consummation of all my wishes but a suitable establishment, and this circumstances scemed to farour-circumstances that appeared to me at the time to be most propitious, but which afterwards proved to be destructive of everything that could prolong the prosperity and welfare of our family.

I have stated in a former part of this work that my father liad been for a short time in possession of a large concern in London, from which he had retired in farour of the former proprietor, through whose original bankruptcy he became its purchaser. This gentleman was an aspiring, ambitious man, not unlike. in looks and person, the then Prince of Wales, whose style of dress, habits, and manner he was fond of imitating; with an intellect well constituted to be at the head of an extensive and popular establishment, had he confined himself to its legitimate pursuits; but, failing this, he fell into difficulties, and was indebted to his corn-merchant a very considerable sum, at the same time he was in a very 
declining state of health. To extricate himself from the (me, and recover the other, could only be accomplished by the disposal of his very extensive concern.

The negotiation for carrying ont this last resource was left in the hands of the representatives of - at the same time one of the principals in-the firm to which he was so largely indebted.

This gentleman was a man of rery pleasing, I may say insinuating, manners. as well as of good habits of business ; there was rather a benerolent expression in his countenance, that would disarm a man of my father's calibre from any suspicion of selfish intrigue or personal adrantage-indeed, there was a straightforward, honest simplicity, as we thought, in making my parent the first offer of this extensive and, as he represented, rery lucrative concern, that bore the mark of former friendship and a strong desire to serve him; and it required a man of little more penetration than he possessed, to assure himself that all this kindness of mamer and condescension-for he held a high position among the merchants and bankers in the City-proceeded as much, or more, from the prospect he had of securing his debt, should my father fall in with his adrice, and become the purchaser, as it did from the great desire he professed to hare of advancing his fortunes.

But this is human nature, after all: and $£ 10,000$ weighs heary in the scale against the lighter commodities of probity, honour, friendship, or any other good feeling the philanthropist or true Clristian may put in against it. Be this as it may, the more difficult problem to solve is, how a man in my father's position, and with his property- 
which at that time amounted, in land and houses alone, to between sixty and serenty thousand pounds-and deriving as well a handsome income from a business that was no trouble to him; living in the enjoyment of every comfort, and keeping his pack of harriers; should all at once plunge into a concern that required daily application, a capacity for complications, a mind well tutored in the ways and wiles of the world, and a perfect knowledge of the tricks and chicanery which the Londoners deem so high an attainment, to manage with any degree of comfort to his mind or benefit to his interest.

In all these qualifications except the first, perhaps, my respected parent was eminently deficient; consequently he soon became a mark for the designs of an unprincipled set of men within the coaching circle, and among them the individual whom my father's injudiciously large expenditure and liberality had set at liberty was the first to take adrantage of his want of penetration and knowledge of our species-or, to speak more plainly, of the arts and rillany of mankind.

I have dwelt thus long upon the first step towards the ruin of my hitherto prosperous parent and his family: and as in the course of this narrative I shall have occasion to revert to this unhappy subject, I will merely observe that when he first entertained the offer of his professed friend, it is more than probable that a consideration for me and my prospects influenced him to accept it.

I had now arrived at the age of twenty-one, when young men look for a participation in the advantages their parents may have reaped for them, and have it in their porer, without difficulty or inconvenience, to YOL. I. 
bestow. There was no necessity for my expressing a wish on this subject, for my father, anxious to enter on his new engagement, set apart a portion of the business at Portsmouth for my individual and independent support; and having already sanctioned the matrimonial connection I had formed, he advised an early settlement of it-that as his time would now be wholly taken up in London, I might devote mine to looking after his interest, as well as my own, in Hampshire; instead of spending it in taking long journeys, and rambling over the heaths, and studying the natural curiosities and antiquities of Dorsetshire.

Accordingly, a house that he had recently purchased, under peculiar circumstances, for $£ 3000$, was handsomely furnished for the reception of a newly married couple, and I lost no time in making the object of my choice the mistress of a modest, though respectable abode. To witness the ceremony, I invited the friend and companion I have before spoken of, and his wife, to accompany me; and my elder sister being already on a visit to the family of my intended, everything passed off without any remarkable incident, except that it was quite an event in the old town. Young maidens strewing flowers, old matrons smiling and curtseying in our path, and there were other symbols of gratulation and respect, which denoted that one, at least, was an especial farourite in the sphere in which she mored. and lived among those whose esteem she had gained, and who now mixed tears with their smiles at her departure.

A few days after my arrival at home from the wedding trip I had to appear first before the grand jury - then in court at the quarter sessions-before the Recorder of 
Portsmouth, afterwards Mr. Justice Burroughs, in a case of false imprisonment, that nearly caused a rupture between me and the friend I had recently selected as my companion upon so happy an occasion.

About five or six weeks before that event, the L.S.the society I have before spoken of-spent the evening with a member who lived at some little distance. In returning, three of us, whose homes lay in the same direction, were walking quietly together. My friend's voice, which was at no time a falsetto, attracted the notice of the sergeant of the guard, who, with two of his men, were going the rounds; he challenged us, and demanded the countersign.

My friend, not being accustomed to obey so peremptory an order, himself commanding at the time the volunteer rifle corps, a little altercation ensued, which ended in all three of us being taken to the guard-house, where we were detained some little time; but, on the arrival of the field-officer of the day, were set at liberty.

This breach of the law by the military, in interfering or imposing their authority on peaceful citizens, we were determined not to let pass unnoticed. We therefore applied to the magistrate for a summons against the sergeant, and he, on hearing our complaint, with very little deliberation committed him to the sessions for assault and false imprisonment.

On the day appointed, when we all three attended, my friend's case came on first; after hearing the evidence, which was very clear and concise, the jury found the prisoner guilty, and the Recorder sentenced him to one week's further imprisonment. 
It then came to my turn, when, addressing the bench, I said that, as the prisoner had already suffered six weeks imprisonment, and had been sentenced to another, I should beg leave to withdraw iny prosecution, as my wish was certainly to punish, but not to persecute; and, as the law had been enforced, and the liberty of the subject vindicated, I was quite satisfied.

The third followed my example, and the sergeant was removed from the dock.

My friend was almost bursting with rage at what he called our pusillanimity, while I had won golden opinions from the court and liecorder. 'The latter, rising, complimented me very highly, saying he had never witnessed in the whole of his legal career such an act of well-timed forbearance, expressed with such earnest and kind consideration, and begged to know my name, that he might append it to a note he should make of so praiseworthy and uncommon an occurrence.

At this my friend appeared extremely mortified, which he did not fail to express in very angry terms; but in a few days his own good sense prevailed, and the excellent understanding between us was restored, and never afterwards jeopardized.

I will conclude this diversified chapter with an occurrence of a different nature, but one that terminated before a similar tribunal.

The population anong whom I resided included a greater portion of that ancient people who are to be found in almost every nation under the sun, than any other city or town in the kingdom, London alone excepter. Whether it be that the locality affords a more 
favourable arena for the exercise of their peculiar virtues, or whether they possess an inherent right to administer to the wants of our soldiers and sailors on their return from abroad, and therefore choose this spot, and other's like it, that they may the more readily relieve them, it is not necessary here to inquire; let it suffice to know that they formed not the least flourishing part of the community.

Among the most conspicuous of this otherwise interesting race was one who, away from his other pursuits, would pass himself off for a sporting character, and would often intrude himself into the society of those who indulged in similar amusements. However odd it may appear for a Jew to be a lover of the turf, where the chances of accumulation are not so positive and certain as his ventures mostly are, still we have lived in a time when we have seen one of the same race sharing in and promoting to the greatest extent this national amusement. ${ }^{1}$ He was a man of pleasing exterior and of tolerably good address; his speech quite free from that accent that mostly distinguishes the less wealthy descendants of Abraham.

He bore the same relative position to the brethren among whom he dwelt as does the Baron to his fellows in London, and, like that Leviathan, took his pastime, not in the waters, but on that other element where the greatest quantity of food is likely to be supplied to their ever open and widely-extended jaws.

I was riding with others, my associates, to our annual

1 The Baron Rothschild. 
hunt races on Soberton Down-one of those spots that seems set aside by nature for the training-as well as deciding the merits - of the different animals that had to compete for the several prizes. We were joined on the road by the sporting Israelite, mounted on a good hack; and chatting, as we trotted along, about who was to be the winner in a particular race, I laid a bet with him of five pounds, that resulted in my farour. Ire rode home together, but not a word was said about the bet, and he joined us at a hasty-got-up dinner at the first inn we arrived at. The cloth being cleared, and the bottle going round, to which all of us did ample justice, I took occasion, from some observations that fell on the day's amusement, to hint that I had won five pounds of him, and requested, in polite terms, that he would give me the money; instead of doing so, he denied the bet, and in the course of the altercation that ensued, in which I may have led him to guess at my ulterior purpose, he smiled contemptuously, and called me a smock-faced boy.

It was true I had not yet cultivated those ornaments to the risage of which he possessed an exuberant growth, though not to the extent of the great millionaire of the present day; but, believing that I had already reached to man's estate, the insinuation roused my irritability, and, jumping across the table, I insisted upon his paying me, or leaving the room. He declined to do either, as parting with his money was quite contrary to his creed, and the alternative he disputed my power to enforce. I felt that I had right on my side, and I also felt that I had the majority of the room on my side, and that he was no welcome visitor. I therefore took hold of his collar, and 
dragged him to the door, downstairs into the street, but not without some little trouble. When there, he showed fight, and we both rolled in the road together, and, upon one or two of the others coming to see the result, he walked muttering away.

A few days after this umpleasant affair (for I never got my five pounds), I was presented with a writ, at the suit of this said Israelite, for assault and battery, in which he laid his damages at $£ 100$. This gave me not the least uneasiness, as I knew that my friends would make common cause with me.

The trial came off at the next ensuing summer assizes, at Winchester, before Mr. Justice Gazelee, a Portsmouth man. We had engaged the leading counsel on the circuit. The case was called on, and the court was crowded. After the usual argument by counsel on both sides, and the examination of witnesses, the judge summed up; and adverting to the trivial nature of the case, and dwelling with emphasis on the provocation given by the plaintiff's calling the defendant a smock-faced boy, his Lordship told the jury the smallest coin in the King's dominions would be sufficient remuneration. The jury, without retiring, returned a rerdict, damages sixpence. I was standing in an elevated position, directly opposite the judge, and at the moment threw a sixpence on the green cloth, round which the counsellors sat, which elicited a loud laugh from the whole court. We then celebrated our victory at the "George," orer" an excellent dinner, at which the volubility and antics of a London waiter added amusement to our carousals.

It was full twenty year's after this occurrence when, 
officiating on the drag on which I spent so many year's of my life, that my way-bill instructed me to take up an inside passenger at Doctors' Commons. I stopped, and a middle-aged gentleman got in, making three insides; on my pulling up at the "Bull," in Bishopsgate Street, where we also booked, a lady presented herself with a child; she took the fourth seat, and when the husband, who was an outside passenger, was about to put the child in also, the gent from Doctor's' Commons demurred, and said he would not allow it.

I was then appealed to, and I ventured an explanation; but all to no purpose. We were allowed to carry four insides by Act of l'arliament, and no more; and no more would he allow.

Now, being pretty well up in Acts of Parliament relating to stage-coaches, with due deference I begged leare to observe that the Act to which he referred expressly says that a child in the lap under seven years of age shall not be counted as one passenger, and that such child shall not be deemed in excess.

Losing his temper at being thus contradicted on a professional point, he said,--

"You do not know who I am, sir."

"Tes, sir, I do," replied I, " and have had that honour many years. You are Mr. Serjeant Pell, and you once defended an action for me at Winchester assizes, much to my satisfaction and that of the court generally, of which you were the leading star."

"Have the goodness to shut the door, sir;" which I did, after putting in the child, a great bouncing boy, a very little under the prescribed age; then mounting the 


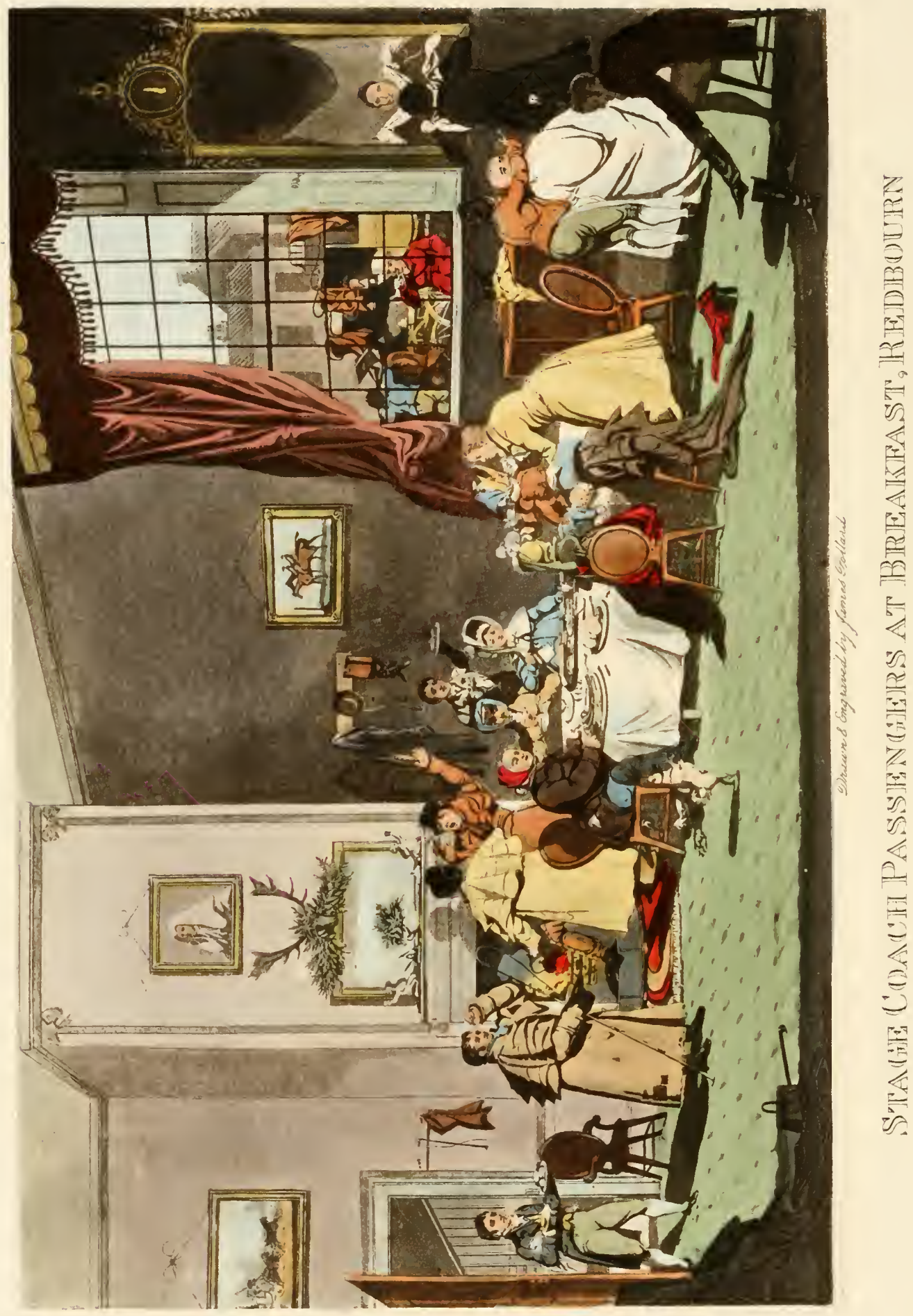


box, I drove off, leaving him to ruminate on the point of law.

On our arrival at the usual place for refreshment, I did not, as was my custom, go in and take my lunch with the other passengers, thinking it would be unpleasant to the learned Serjeant. I therefore seated myself alone in the kitchen.

I had not been there long before he entered, after inquiring for me, and observed,-

"Coachman, I find I was wrong just now, and was much too hasty in my expressions."

I begged he would say no more. I was rery sorry for the inconvenience to which he was put, but he must be aware that it was quite unaroidable on my part.

He then asked,-

"Pray, what action was that you alluded to, in which you say I was counsel-I ought to remember it?"

I briefly recounted the particulars.

"Oh, I now recollect it perfectly well; and you, I suppose, were the smock-faced boy that obtained so farourable a rerdict?"

I bowed assent; and here, the time being up, my meal and the colloquy ended at the same time.

Having an estate on the road, he and his family were frequent customers, and we were ever after the best of friends. 


\section{CHAPTER VIII}

\section{PORTSMOUTH IN 1814, AND PROSPERITY}

The War-Trafalgar-Sir John Moore-Sir David Baird-CorunnaDisembarkation-Walcheren_Camp at Southsea-Embarkation - The Earl of Chatham-Sir Richard John Strachan-Prosperity of Seaport Towns-A Profitable Business-A Distinguished Military Gentleman; his Wants Supplied-A Dinner and Wine - The Bill-An Interesting Discovery-Drive to Reading and Oxford-An Agreeable Surprise-Prompt Resolve-Clouds in the Distance-The Russian Campaign-The Campaign in Germany-Peace-The Visit to Portsmouth-Insanity of the People-Prince Blucher-The Emperor Alexander-The King of Prussia-Napoleon.

A the time I commenced life-that is, when I married, and possessed an establishment of my own-the town in which I resided partook as much, or more, than any in England, of the benefits arising from a large expenditure of the public money. 'The war was then at its height. Though the victory of Trafalgar had all but annihilated the naval power of France, our blockading squadrons were kept in sufficient force. The channel, too, being infested with privateers, fitted out, for the most part, in the smaller ports, gave ample employment to our cruisers; while, to preserve our command in the Baltic and Mediterranean Seas, - to provide convoys for large fleets of Indiamen-and otherwise protect our commerce in every quarter of the globe,- the employment of all the 
means at the disposal of a great nation was required to sustain the naval superiority we had gained. Large armaments were fitted out. Troops constantly embarking and disembarking caused a sort of tidal influx and effux of strangers, crowding the streets with naval and military uniforms.

The ill-fated Sir John Moore, I recollect, whose pensive brow, indicative of all that was brave and noble, reflected the lofty intelligence of the venerable author of "Zeluco" -arrived from Sweden, whither he had been sent on a futile expedition, to recruit and refresh his army of 10,000 men, prior to his joining the British forces at Lisbon, where the famous Convention of Cintra had been lately signed. There he took the command, and marched through Portugal into Spain, where, joined by Sir David Baird, who had disembarked at Ferrol with 5,000 men from Ireland, he advanced upon Madrid. He har not proceeded far before he was compelled to retreat before a superior French army, commanded by Napoleon in person. with Marshals Soult and Ney, and the élite of his staft.

A battle was fought before Corunna, in which we claimed the victory. The General-in-Chief was killed, and hastily interred. The second in command was severely wounded, and as hastily embarked, ${ }^{1}$ as did the remains of that fine army that had left our shores but a twelvemonth before, completely equipped, and in perfect order. What a contrast was presented to me, when, in

1 Sir David Baird was borne to his lodgings in the High Street on the shoulders of his men, seated in a wine-cask, with the loss of an arm. 
company with my friend, I witnessed them straggling up Portsmouth streets, in a most deplorable condition ; many in a state of intoxication-some with fire-arms, some without-some with nothing on their heads, others without shoes, their regimentals discoloured and torn,--they presented a true though lamentable specimen of a retreating army. How it was that two battalions of the King's German Legion marched up after them in good order, with all their equipments, and each man with a spare pair of shoes strapped on his knapsack, I never could understand; but I remember it called forth some severe remarks on military discipline, or the want of it, from every respectable obser'rer.

This was speedily forgotten in the preparations that were made the following Spring for the not illconceived, but badly executed diversion to the waters of the Scheldt, better known in history as the Walcheren expedition. A large camp was formed on Southsea Common, and battalion after battalion of regiments of the line, together with the Guards, assembled from all parts of the two kingdoms. After remaining about a month, they were embarked, one hot day in July; in flatbottomed boats provided for the purpose, on the beach at Southsea. They went off in excellent health and spirits, amidst the cheers of a multitude of spectators, amongst whom I and my friend were not the least conspicuous, either from the observations we made on the appearance of the men, or the hearty rociferation of our cheers. Transports and men-of-war were at Spithead to receive them, and I believe a finer or a larger armament never left the shores of Britain prior to that time. In the 


\section{SIR RICHARD S'TRACHAN}

Downs they were joined by the remainder of the expedition, under the Earl of Chatham, General Commander-in-Chief, and sailed away towards the point of their destination.

The result of that unfortunate expedition is too well known for me to dilate upon: that fine army, a great portion of which I had but a short time before almost daily visited in camp, was suffered, either from the incapacity of their general or some egregious blunder, to become, from inactivity, the rictims of the pestilential swamps of the Scheldt. When the veteran commander of the naval part of the expedition, Sir Richard J. Strachan, was asked, after the bombardment of Flushing, what he thought of their operations, he replied, in one of his coarse, off-hand speeches, in which he used to indulge (for he was one of the old school), and which I must not repeat-that we had covered ourselves, not with laurels, but disgrace. The expedition returned, and those of the army that were left returned but the shadows of the men who had departed only six months before in the full glow of health and plenitude of rigour.

I have diverged thus far from the straight course of my narrative, to point out that-while the people generally were discontented at these repeated failureswhile trade and commerce languished and manufacturers stood still-while the newspapers teemed with doleful prognostics of the issue of the war-and the Opposition in Parliament were loud in their denunciation of the continuance of our army in the Peninsula - the maritime towns were reaping a rich harvest, and the one in which I resided profited most of all. Here prosperity 
reigned triumphant-natives and foreigners-tradesmen, high and low-innkeepers and publicans-artisans of every denomination-men and women of all descriptions -from the greatest contractor down to the humblest bumboat woman, or the itinerant organ-grinder-Jews, Germans, and Gentiles, were all making money:- the reader may therefore well suppose I was not in a bad position.

The coaches of which I had become part proprietor were constantly loaded, and the monthly dividends exceeded all that was ever known on any other road, as I had afterwards the means of ascertaining. I took advantage of the large profits accruing from my business to extend its ramifications in every possible way. Constantly in the habit of purchasing horses both in London and country fairs, I was looked upon as a pretty good judge of the animal. My coaches were all well horsed, the teams well matched for pace, and I had them of all colours-grays, bays, chestnuts, roans, duns, skewballs, and blacks-and at the hour of starting they usually attracted the attention of the inhabitants, both civil and military. I hunted with both the Hampshire and the Hambledon hounds, was generally well mounted, and always took care to have fast trotters to drive either in single or double harness, occasionally exhibiting in a tandem.

Thus I became well known, and was often applied to by officers in the garrison and gentlemen in the neighbourhood for a charger, a good cob, or a pair of match-horses for a carriage, and generally managed to supply their wants with satisfaction to them and credit to myself. 


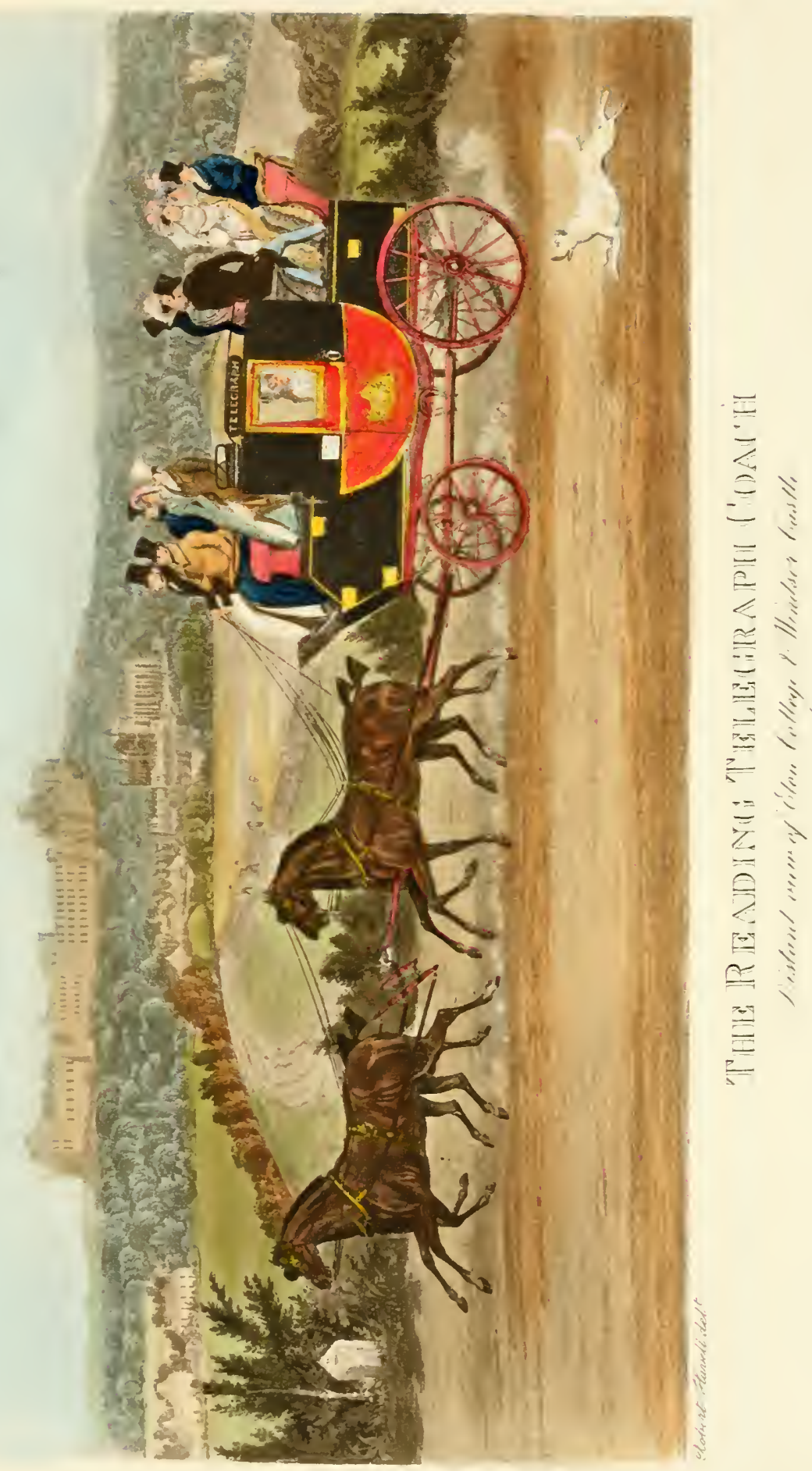


But this sort of business, though very much to my taste among gentlemen, as well as to my own advantage, was not free from those losses to which a want of knowledge of the ingenuity of mankind will sometimes subject the most experienced practitioner, as the following anecdote will show :-

One fine summer's morning a gentleman called at my office, and introduced himself to me as Colonel Verity. He was a tall, military-looking man, genteelly attired in plain clothes. He said he wanted a pair of light carriagehorses to draw a phaton, and had been recommended to me as a person who was likely to supply him.

I told him I had not a pair at present that would be likely to suit. He professed to be in no immediate hurry; he was staying at Ryde with his lady, for the benefit of her health, and a fortnight hence would do.

After a little further conversation I walked with him to my stables, and there pointed out to him a horse that I thought was about the stamp he required. He liked him very much; and asked, provided I could match him in size, figure, and colour, what the price would be.

I told him I could not exactly say, but I thought it would not be less than $£ 150$, as it might be difficult to find a match. 'l'his sum he consented to give, if he liked the other horse as well as he did this; and so we parted.

It was not long before I accomplished this part of the task-indeed, I had not to go out of the town to do so. An officer on the staff wished to purchase the horse in question, to match one he already had, but as we could not agree about price, I bought his; and then wrote to the gentleman in the Isle of Wight, to acquaint him with 
my success, and that the pair of horses were at my stables for his inspection and trial.

He came accordingly-I had the horses put to, and drove them with him some two or three miles; then gave him the reins, and requested he would drive them himself. He said he was quite satisfied, and would have them; he would, with my permission, take up his servant, who he had brought with him, and drive them for another half-hour. So he did, and on his return I asked him to stop to dinner, as the boat did not start for Ryde till seven in the evening.

Now, my father happening to be at Northampton, and knowing my penchant for things a little in the superlative degree, in gastronomy above all other arts, had sent me a prime saddle of Leicester mutton; and I had invited the friend I have so often spoken of, and two others as fond of a good dinner as ourselves, to partake of it.

The gentleman sat down with us, and made himself very agreeable; and I made him as welcome as my house and well-stored wine-cellar would admit. While the wine was going round, he took occasion to exhibit a handsome gold chronometer, which two of my visitors, one a considerable silversmith in the town, the other my wife's brother, who was a good judge of such articles, pronounced to be most valuable; and of course the owner was considered to be a perfect gentleman. W'hen the time arrived he took his departure, telling me he would come over in the morning, pay for the horses, and take them away.

He came according to his word; and as I fully expected was about to pay for the horses, instead of 
which he asked me if I had any objection to take a bill. I certainly thought the request rather an unusual one, but the beautiful gold chronometer was fresh in my vision, as well as the jewelled rings on his fingers, so that I did not long hesitate, but said, "Certainly not, provided you can give me a satisfactory reference." He having named a gentleman, the son and co-partner of an alderman of the City of London, and an old friend of our family, I readily assented.

Accordingly the bill was drawn, signed, and accepted, and the business was so far settled. I took the bill, which I carefully deposited in my cash-box, and he took the horses.

I thought nothing more of the matter till about three weeks after, when I had occasion to go to London, and, on entering my father's breakfast-parlour, found there the very gentleman I had been referred to. This incident naturally recalled the individual to my mind, and I asked him if he knew such a person as Colonel Verity.

"Yes," he said, "I do, and know him to be one of the greatest swindlers in or out of London, and I hope you have had no transactions with him."

On my relating the circumstance, he assured me that the bill was not worth one farthing, and said I had better get the horses back if I could.

I returned home, a day or two after this interview, and found that the plot had been blown, and that the gentleman had decamped without bidding farewell to those who had good reason to remember so accomplished an adept in his art.

The Hampshire weekly paper had been published, and VOL. I. 
the man's ingenious manner of living made known, while the very easy method in which he provided himself with a pair of handsome carriage hor'ses, at the expense of a young coach-proprietor, was jocosely exposed; even the hospitable treatment of his gentlemanly visitor was named, as well as the chronometer and its appendages, the writers intending-good-naturedly, no doubt, for I knew pretty well where they got their information-to show up the dupe as well as the artful professor of practical economy. I took it in good part, as I did the bantering of my friend, who was not behind the rest in roasting me for my credulity.

However, the paragraph had the desired effect. Among the rictims of the blandishments of this hero was a linendraper, of whom he had purchased goods to the amount of about $£ 210 \%$, for which he tendered him a bill for $£ 20$, receiving the difference in cash. Two or three mornings after the issue of the paper, this person came to me with a letter he had that morning received from a young man at Reading, who had lived shopman with him, stating that a gentleman and lady had driven into the town in a phaeton and pair of bay horses, answering in every way the description given in the Hampshive Telegraph. Thither I was determined to proceed, offering to take the linendraper with me, free of expense, but arranging, at the same time, that if we thought it necessary to follow in pursuit beyond that place, we were to share the expense.

I then had my horse put to, drove with him to Petersfield, took a second horse out of the mail stables, and arrived at Reading about dusk. After taking some 
refreshment, my companion proceeded to find the young man who had given him the information, while I went to call on a horse-dealer in the town, with whom I sometimes had dealings. A little to my surprise, he told me that "a Gent." had been there that morning in a phaeton with a pair of horses, wishing to sell one of them or make an exchange, but as they could not agree he had driven arvay, and, as he believed, taken the road to Oxford. I looked round this man's stables by candlelight, and returned to the inn, where ny companion soon joined me, and corroborated the information of the horse-dealer as to the route our game had gone. After a little consideration on his part, he agreed to accompany me to Oxford to endeavour to find the thief. I ordered a chaise out to Wallingford, which we reached after the people had gone to bed ; consequently, we were some time before we could get another chaise, so that we did not arrive at Oxford till between three and four o'clock in the morning. Now here, too, lived a horse-dealer, with whom I was acquainted, in that part of the city, called Holywell; I therefore ordered the boy to drive us to the King's Arms. Upon alighting, my friend, who was getting into years, was very much fatigued, and wished to go to bed, which he did. I having slept pretty well in the post-chaise, preferred sitting by the kitchen-fire, which in such houses are never suffered to go out. Rousing myself at daylight, I walked into the yard, and, going into the only stable that was open, beheld, to my agreeable surprise, my two hor'ses.

I immediately resolved upon removing them myself to the horse-dealer's who lived over the way, and went up 
to the head of one of them to undo the halter, when a man in a rough great coat, and with a very gruff voice, asked me what I was about.

I told him I was about to take the horses away, as they were my property.

"Touch them at your peril," said the man.

Nothing daunted, I proceeded to put my intention in force, when very high words ensued, and I was anticipating something like a push or a blow, when he produced a paper signed by the mayor of Oxford, authorizing him to keep possession of the said horses.

Satisfied with this, I desisted, and remonstrated with the man for not telling me as much before.

"So I should," he replied, "had you not been so hasty."

I acknowledged my error, and rewarded him with half-a-crown; went in and asked him to follow me and have a glass of purl, for it was a cold morning-not that I joined him in that farourite bererage of a certain class. He locked the stable-door, and told me that the mayor, having received information of the ingenious contrivances of the pseudo-Colonel, and of his entry within his jurisdiction, had had him taken into custody ; and that he was then in Oxford Gaol, and would be brought up before the magistrates at eleren o'clock.

When my fellow-traveller came down to breakfast I informed him what had taken place, at which he seemed highly pleased, and, after finishing our morning's meal, we repaired to the town hall. To our great disappointment, we found the prisoner had been discharged; and on making our case known, the mayor referred us to the town-clerk, to whose office we went; when that func- 
tionary plainly told us that, as our bills had yet some time to run, we could not proceed against the man either criminally or civilly. The latter I very well knew, and it appeared the rascal had made terms with the person who had caused him to be arrested, and now the man himself, entering the town-clerk's office, offered to arrange matters with me.

Saying I would have nothing to do with such a scoundrel, I walked out; and the mayor having withdrawn the officer, I took the horses away. And thus, reader, terminates this what in seafaring language would be called a long yarn.

I was subsequently served with a writ for unlawfully taking the horses; but after the first process-of which I took no notice-I heard no more about it.

I got my horses safe home, and sold them to a gentleman in the town for $£ 120$; so I was not much the loser, while the linendraper was not so fortunate, for he never got a farthing.

It was during this brief period of my prosperity, which to look back upon appears like a fitful dream, that I frequently conferred with my friend upon its probable and speedy termination.

He would treat such thoughts, not with contempt or ridicule, or indifference, but with a tacit acknowledgment that evinced his dislike to the subject.

Victory after victory had only induced our Govermment to make the most gigantic efforts, in concert with our allies, to complete the overthrow of the vainglorious man whose elevation cost his country so heavy an expenditure of treasure and blood, and in furtherance of 
whose aim at universal conquest the people of Europe were called upon to sacrifice their homes, their children, and their liberties.

The disasters of his Russian campaign were crowned by the battle of Beresina, where, as one of our most eloquent English authors says-had he been the hero he raunted himself, "on the bridge of Beresina he would have died," and not have survived the loss of those brave and numerous cohorts that his insane ambition led into the frozen regions of Northern Europe-a force that more resembled the army of a Cyrus or a Xerxes than that of a modern European power.

'This decisive and ruinous conflict sealed the first act of his downfall ; while, in the ensuing campaign in Germany, the battles of Lutzen and Bautzen sustained him for a time, till the issue of the well-contested field before Leipsic induced him, for his own personal safety, to enact the same bloody tragedy on the Elster he had practised before on the Beresina, which as effectually closed the second act. And now the curtain drew up for the third and last.

My friend and I read with joy the repeated accounts of the advance of the allies towards the French metropolis, and joined in the general exultation that the bold achievements of our countrymen under the great Duke called forth, on their passing the Pyrenees, and slaking their horses' thirst in the pellucid streams of the French territory. The constant excitement that existed in our town only served to add to the inflation which had chiefly buoyed up the fortunes of its inhabitants for so many years; but as every successive account arrived of the 



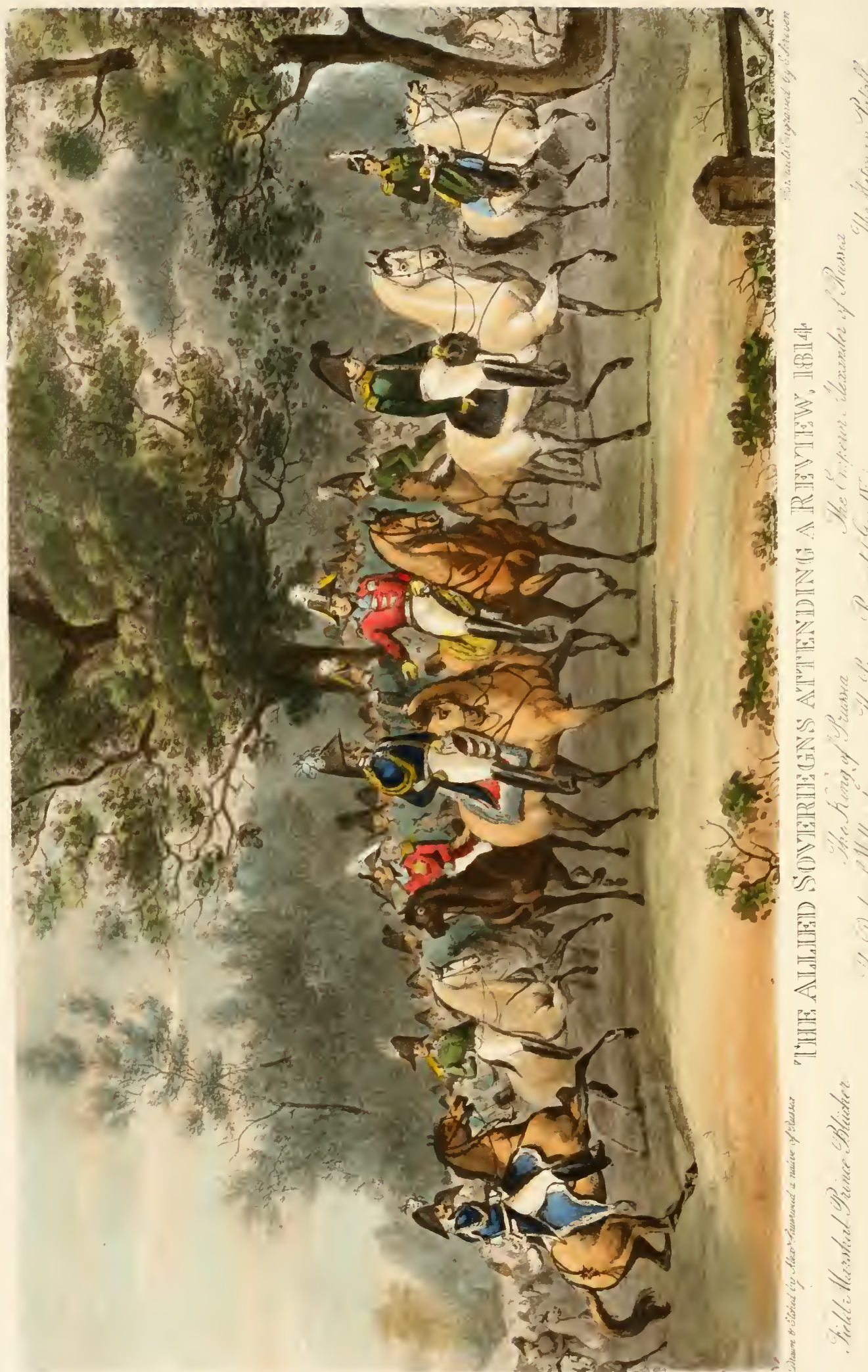


defeat of the enemy, I could plainly see that the collapse, which I should be the first to feel, was near at hand.

At length the allies got possession of Paris. The Emperor abdicated; hostilities were suspended-the Bourbons were recalled-peace was proclaimed. When diplomacy had run its course, and settled the affairs of Europe, and the man who had set the Continent in a flame, and trod its sovereigns under his feet, had been sent off to Elba, his conquerors, to further gratify themselves and their followers, prepared to risit England.

This was the signal for such scenes in the old town as had never been before witnessed. It was soon made known that the foreign potentates, with the principal generals or commanders, would accompany the Prince Regent on a tour of inspection to this grand naval arsenal and garrison. They had already excited the gratification and curiosity of the metropolis, and were now about to transfer their august persons to be scanned and idolized by the provincials.

Every preparation was made by the authorities for the proper reception of such guests, and every means at the disposal of the more humble inhabitants were made available for the enjoyment of their London or country relatives. Consequently, not only the town, but every village and hamlet within reach, was crowded with visitors. Strangers daily poured in from all quarters. Not a bed was to be had, and such places were set aside for sleep as would not be thought of for such a purpose on ordinary occasions.

I, with some other of the inhabitants, kept open house, 
and, living two miles on the London Road, had never any lack of customers. My wife's relatives and friends from Dorsetshire-my own from London-my married sister and her husband's family, my co-partners from Northampton and Salisbury, with their wives-both admirable and amiable specimens of their sex; my naval acquaintancesamong whom was the lieutenant officer of my watchand last, not least, my old friend the sixth mate, who, as I have before stated, was unfortunately killed on his next voyage_all made my house their home. One of my own spare coaches, with four good horses, was at the door every morning to take us to the grand point of attraction.

The great wish of all was to see and shake hands with their Imperial and Royal Majesties, with the veteran Blucher, and the Hetman P'latoff. The two former were lodged, one at the Governor's, the other at the Commissioner's House in the Dockyard; the latter at hotels; and one and all, young and old, rich and poor, were smitten with the same mania-that of following in crowds the footsteps of those august personages. So high and so far did this feeling obtain, that the epoch was ever after called "the insanity week."

The first day a review of the fleet at Spithead took place; and never before then was that anchorage so crowded-the whole space between the harbour and the island was covered with ressels of every description, from the Royal Yacht, with her cargo of illustrious visitors, Sovereigns and Princes, down to the poor bumboat-woman's humble craft laden with her youthful family. I had taken care to engage for my party the pilot boat of the man who har so kindly, but a few years 
before, eased me of my four dollars, a fine cutter-rigged ressel; and had given the command to my friend the lieutenant, who manœuvred her so well, as constantly to keep us in view of all the remarkable doings of the day. On one occasion, by his superior knowledge of naval tactics, he succeeded in placing us in full view of the sovereigns, to the exclusion of another ressel, laden with officers and ladies of distinction; which elicited the praise of all around, evinced by waving of handkerchiefs and other expressions of unalloyed delight.

My friend, in spite of his independent spirit, was infected with the same desire to prove his exultation and partake of the general joy; but the old Prussian commander was his farourite object, and I need not say I agreed with him in all his sentiments. Relying on his tact and address for an interview with this brave old man, whom I had seen from the street smoking his pipe at the window, I waited outside, when, watching his opportunity, he said,-

"Come along with me."

Entering the house, we ascended the staircase, and met the reteran on the landing alone. My friend, with his usual self-possession, addressed him thus briefly,-

"Monsieur, fait mois l'honneur à prenner le main d'un tel grand homme."

"Avec plaisir, monsieur," said his Highness, extending his hand.

"Et mois aussi, monsieur le Marechal, si vous plait," said I:

"De tout mon ceur," replied the old soldier, and gave me a hearty shake; then, with an ".Allons donc," he 
descended the stair's with us, and, taking off' his hat at the foot, wished us good morning.

He was a man, I remember, about the common height, with strongly marked features, rather a prominent nose, with a quick and sparkling eye. The ravages of age had already committed rast inroads on his countenance, which, nevertheless, was still rather pleasing than otherwise.

Our company generally divided, some going off to Spithead, other's to the Dockyard, wherever the scene of attraction led them. On one occasion the Emperor Alexander went with the Duchess of Oldenburgh, his sister, to Haslar Hospital, unaccompanied by the Regent or the King of Prussia; and as some of the ladies of $m y$ company had a particular desire to see him, we took a boat and followed. From its not being generally known that he was going, the hospital was not much crowded. I met him in one of the walks of that most efficient establishment, and, taking off my hat and bowing, he extended his right hand to me. I then introduced my wife. mother, and sisters, in French, when his Imperial Majesty was graciously pleased to hold out his royal hand to them also, which two of the Dorsetshire primitives almost devoured with kisses. His tall military figure, and his real Calmuck features, lit up with a genial smile I have not forgotten.

In the evening there was a superb banquet at the Government house, when the grand parade and the slopes of the ramparts were covered with people of both sexes and all classes.

Although gas was not then in existence, the whole 
palace was brilliantly illuminated; and when the Prince Regent appeared on the balcony, accompanied by his Imperial and Royal Guests, the scene had altogether a most magnificent appearance.

Just at the time, as if it had been previously arranged, the Duke of Wellington arrived from London, and joined the Sovereigns on the balcony. They then all drank to the welfare of the British people, when the cheers of assembled thousands greeted the princely assemblage.

I was there, and from the box of my drag had a capital sight of the proceedings, as had my friends from the roof, much to the annoyance of some of the good people on foot, who began to show unmistakable symptoms of uneasiness at my vexatious intrusion, mine being the only carriage there; therefore, having gratified ourselves with all that could be seen, I turned the leaders' heads, and, without exhibiting any irritability at the impatience of the crowd, quietly drove off:

The next and last day there was a grand review on Portsdown Hill, at which were assembled all the troops in the garrison, and for some distance round. Again were my four horses in requisition; and, pulling up in front of the line, which stretched away to Nelson's monument, we had the pleasure of seeing the Sovereigns ride down.

The Prince Regent, dressed in a field-marshal's uniform, was in the centre; the Emperor on his right hand, and the King of Prussia on his left; and being consequently nearer to us, we had a good view of his melancholy countenance-a countenance that spoke but too plainly of bygone woes; and while sympathizing with his 
troubles, we could but recall the very lenient punishment -if punishment it might be named-with which his oppressor had been visited.

"Instead of being allowed to retain the symbols of sovereignty," I said to my friend, "I would have served him as Timour did the Saracen-I would have confined him in an iron cage, and shown him round the world as a monster." This would not have been in accordance with the spirit that afterwards eroked commiseration for the fallen hero, as he appeared to some morbid imaginations; but it would have been more strictly consistent with common sense and retributive justice. 



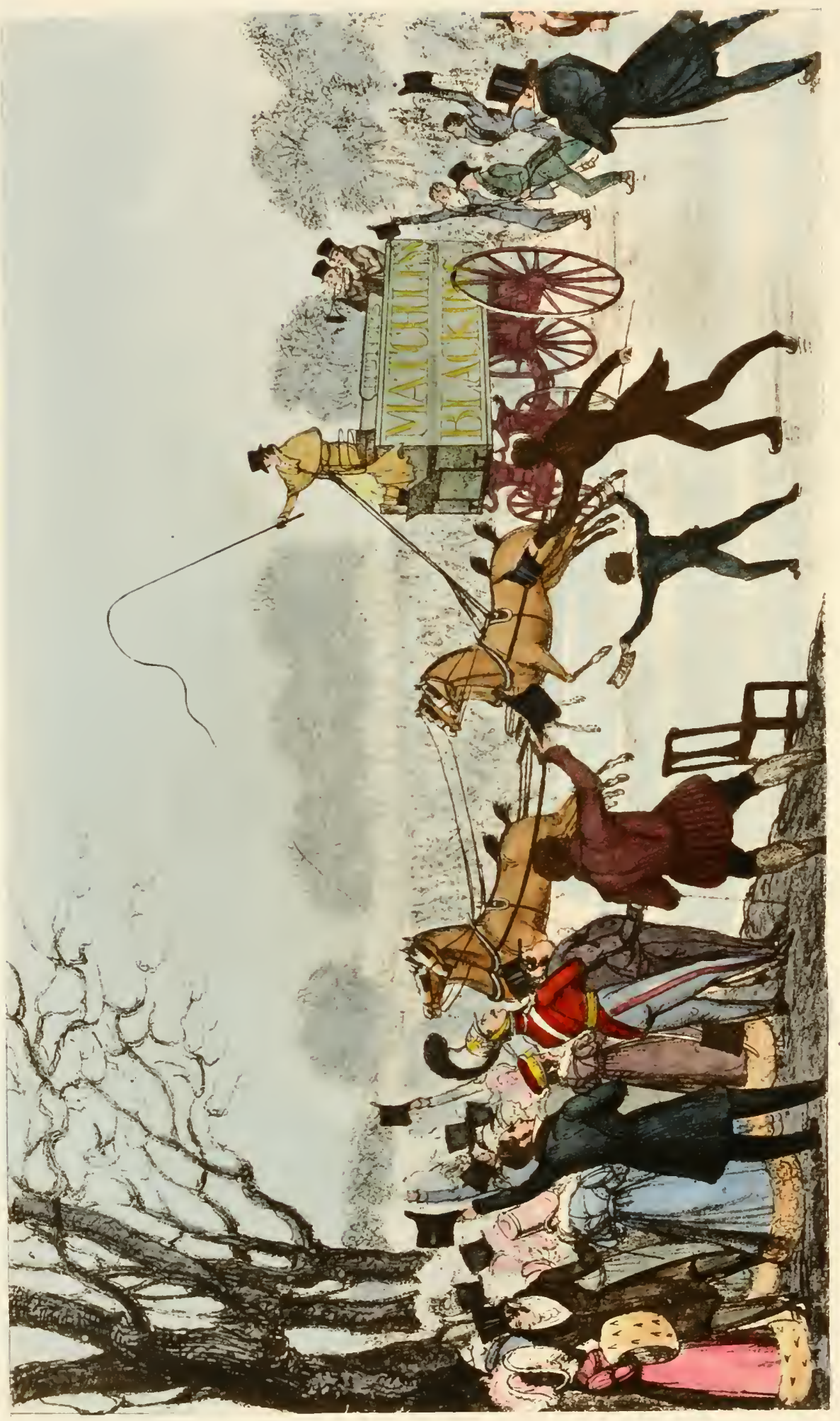




\section{CHAPTER IX}

\section{PROSPERITY CONTINUED}

A Long Frost-Fair on the Thames-Journey to the North-Guinea Pigs-A Younger Brother-Charming Domicile-EdinburghMessrs. J. \& J. Ballantyne-Departure-Deep Snow-Pleasant Ride by Moonlight-Carlisle-Liverpool-Delightful Companions-A Morning's Walk-Peace-Two False Steps-A Master of Hounds-Our Peoples-Scene in a WoodA Yorkshire Tyke-Laughing Philosophy - WhitechapelSomerset House-Portsmouth Dockyard-The Commissioner.

I ought to have stated that the year 1814-a year big with events of rast importance to the nations of Europe -was introduced by a frost which, for its intensity and length of duration, has not been equalled in England in the memory of that respectable authority the oldest

- inhabitant. It was general throughout the island, and was accompanied in many parts with a great fall of snow. Communication by coach or carriage of any sort was, on many roads, for a while suspended. Eren postal arrivals and departures were uncertain, and the mail-bags to important cities and commercial towns could only be conveyed on horses' backs.

A general holiday seemed to be established in London. 'The Thames was frozen over, and a fair held daily on the ice. A bullock was roasted whole near the spot where the middle arch of the present bridge now stands. Crowds 
of people, vieing with each other in the richness or gaudiness of their attire, flocked at the risk of their lives to witness this unprecedented exhibition, as they have since done to see the performance of some favourite actor, and as they now do to listen to a popular preacher-all for the same reason, to the same purpose, and with the same effect.

I have been thus particlar in recording this remarkable variation in our temperate climate, because circumstances called me a distance of nearly 500 miles from home, a journey at that time requiring some little stamina and exertion.

My next brother, about three years younger than myself, had chosen to be a printer; he was accordingly apprenticed to the Messr's. Hansard, the king's printers; and his time having nearly expired, it was thought advisable, to complete his instruction in this wide-spread art, that he should spend the last year or two with Messrs. Ballantyne, of Edinburgh, whose establishment was then considered the most complete in Europe. 'The terms being settied, I was sent for to accompany him to the northern capital. Although I had my hands full, and could but ill afford the time it would take from $\mathrm{my}$ business, I was rather pleased than otherwise at the prospect of the journey.

I quitted home the last day of the old year; and, learing my wife and child with my married sister at their comfortable house on the Downs, drove to Petersfield, where I got into the night coach, and arrived safe in London the following morning. The next day we started from the "Saracen's Head," Snow Hill, in the old York 
coach, the "Nelson." There had been as yet no stoppages on that line of road: still the journey was most tedious, even for those times: while, to relieve the weariness, I once or twice got out, thinking to dirert myself with driving; but, what with slippery roads, bad cattle, and worse tackle, I could make no hand of it, and was glad to get inside again, to preserve myself from the bitter, biting atmosphere.

Arriving at the "Cock," at Eaton, a large coach and posting-house, our first coachman left us; and the guard, giving the way-bill to the proprietor, informed him who we were, when he became very attentive and courteous to us.

In those times the London man was held in great estimation by the country proprietors; and so far had this feeling been carried by my father's predecessor, that he was almost worshipped by them. This arose chiefly from his gentlemanly manners and good principles, so widely different from the low cunning and paltry means that were afterwards practised.

Now, the guard had taken up two soldiers on the road, and from good feeling, as I thought, had, not long before we stopped, put them into the hind boot, and covered them up--the boots in those times being made rery spacious, and opening at the top.

On coming out from the house, where we had taken some refreshment, the proprietor took his leave of us; and his notice being attracted to the hind boot, he called the guard, and asked him what he had got there.

"Only a couple of guinea-pigs, sir," said the gund very innocently, not observing the leakage that had caused 
his master's question, and perhaps aroused his suspicion, and was proceeding to his seat.

"Stop!" said the master ; I never saw a guinea-pig." Getting on the hind wheel, he opened the boot and looked in, when, to his great surprise, he saw two grenadiers.

"Well," said he, looking at the guard, "they are two beauties; where did you bring them from, guard?"

'This was rather' a question ad hominem. My brother' and I getting in, we did not hear any more of the dialogue, and saw no more of the guinea-pigs.

After travelling all that night, we arrived at York the next afternoon, when, in dismissing the guard with his fee, my brother, who would be a little waggish, observed that guinea-pigs were pretty things, but not always agreeable in the sight of strangers.

We continued our journey to Newcastle, where we arrived the following evening. Having acquired an additional number of passengers - it was a six inside coach-the dull monotony of the surrounding country, covered as it were with one white sheet, calling for little or no observation, could only be relieved by conversation ; and my brother, who possessed a good flow of animal spirits, kept us alive by some piquant remark on every little occurrence, or by otherwise evoking the laughter of us all by his powers of mimicry, which he would exercise indiscriminately on those present as well as absent.

He was altogether an oddity, and had a strong inkling for the stage; and when I mention that the celebrated Keeley was his brother apprentice and close associate, the reader will not wonder at his imbibing and possessing a 
fund of amusement, aided as he was by a comic expression of countenance.

At Newcastle we slept, and very glad was I to get a night's rest, though it proved a short one, for the coach left early next morning for Edinburgh, where we arrived about eleven at night.

We took up our quarters at the hotel where the coach stopped, and were conducted to the very top of one of the lofty houses in the old town of Edinburgh. The room we were conducted to for our domicile, with its furniture, was of the meanest description, and void of every comfort; and I went to sleep with but a poor opinion of the cleanliness of the inhabitants of the modern Athens, when I lay down on what was not worthy to be called a bed.

In the morning I awoke in the greatest fright, for on my eyelids gradually relaxing, my sight rested on an immense rat on my shoulders, that sat gazing full in my face. My shouts of fear or horror drove the hateful vermin away, and roused my brother from his slumbers, who jumped to my assistance, supposing I had suffered some grievous injury. I soon recovered my senses, and, hastily dressing ourselves, we beat a retreat from this filthy cock-loft.

On remonstrating with the landlord on the badness of our accommodation, and assuring him we were neither recruits nor tramps, he apologized by saying he was gone to bed when the coach arrived, and was not aware what part of the house had been allotted for our dormitory.

I then presented him with one of my father's cards, and stated we were going to call on the Messrs. Ballantyne, if he would have the goodness to direct us.

VOL. I. 
The latter name was sufficient to call forth all his attention, and to insure us more agreeable treatment.

After performing our toilets in a far different apartment, and partaking of an excellent breakfast, we went out; and, it being Sunday, we entered the first place of worship we came to, which happened to be a newlyconstructed edifice, a church of considerable dimensions, but by no means too large for the congregation.

The service-which did not impress me with that humble though awful adoration of the Deity which our own sublime liturgy never fails to do-being over, I went at once to deliver my credentials at the house of the firm.

I camnot say distinctly which of the gentlemen I saw, but I felt from the length of our conversation--which terminated in an invitation to dinner-that I had not made a very bad impression, while our new acquaintances' very urbane manner was equally satisfactory to me.

We returned after visiting Arthur's Seat and Holyrood, and I spent, J think, one of the most pleasant evenings I ever remember-the conversation turning principally upon the literary productions of the day.

The author of "Waverley" was not then known, but speaking of the poetic works of Walter Scott, Ballantyne seemed very attentive when I expressed my admiration of the "Lady of the Lake," the simplicity of the tale, and the beauty of the imagery, and attempted to point out good specimens of his powers of description, as well as of his genius, displayed in grouping and classifying the characteristics of his native country. 


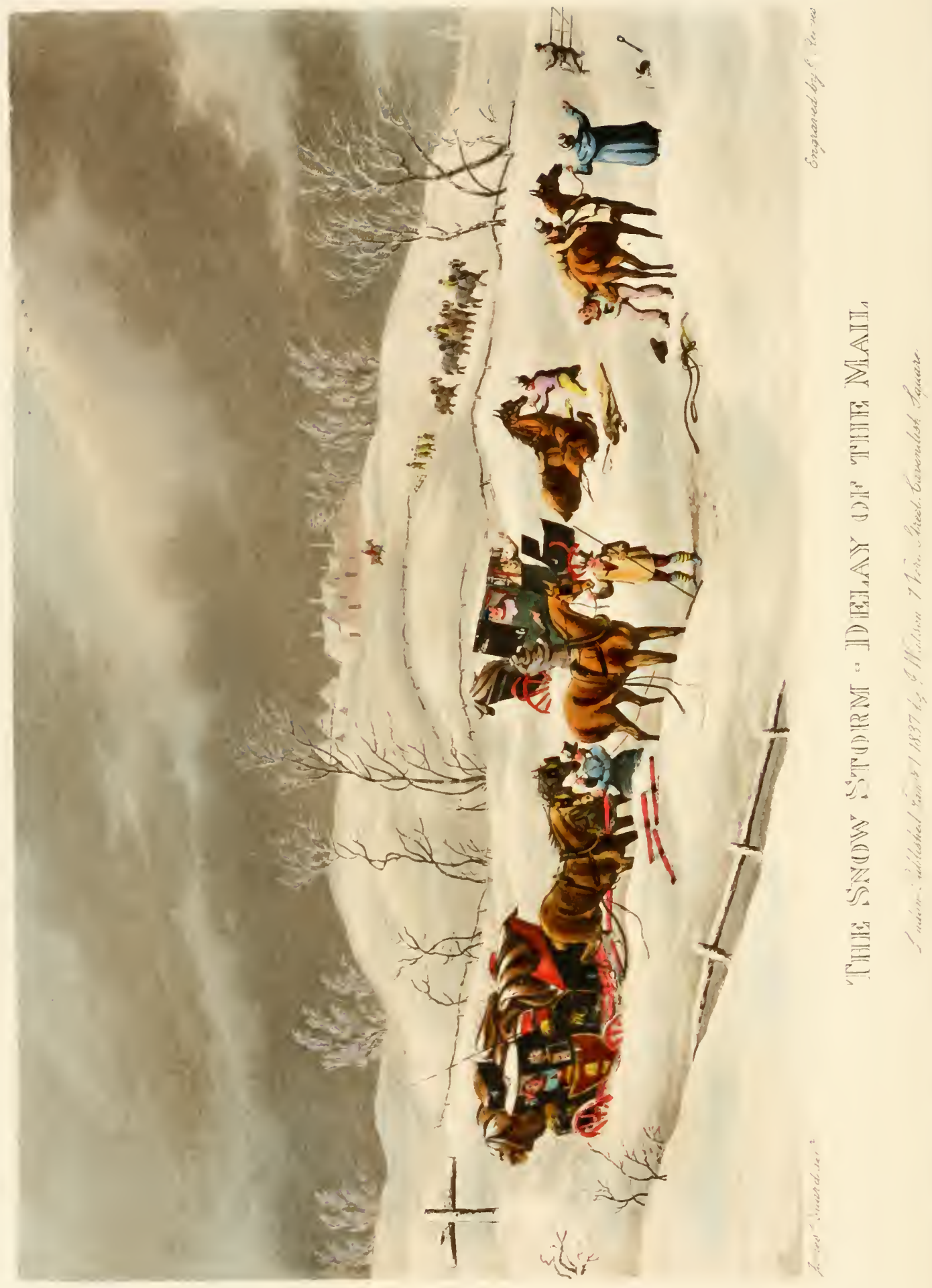


On the Monday morning I again called, and after permanently settling my brother, took leave of my hospitable and very intelligent entertainer.

The weather, which had been particularly bright, though extremely cold, changed on Monday and became very gloomy.

Anticipating a heavy fall of snow, that might cause me to be pent up in Edinburgh, I got into the Carlisle mail that stood at the door of the hotel, as soon as I had discharged my bill, and, taking an affectionate leare of my brother, was quickly outside the Canongate.

My companions, three in number, proved to be coach proprietors, who lived at different stages, and disappeared one after the other, till I was left quite alone.

The snow, as I thought it would, had commenced, and had already obliterated all appearance of a track or road. While stopping, I asked the guard the cause of the uneasy motion I had experienced. He told me that the vehicle was obliged to deviate from the road, in consequence of the obstructions the snow had created.

Arriving, after some little delay, at Hawick, I was shown into a parlour where blazed a beautiful fire, which seemed to offer me a warm welcome I felt very much disposed to accept.

Presently I was told by a tall Scotch damsel that the coach could not proceed any farther, and that the coachman and guard of the down mail had arrived with the horses and bags, having left the coach in the road, it being quite impassable for wheel carriages.

This was bad news for me; however, I sat myself down by the fire, and had resolved to make myself 
content; but the thoughts of home, and a business, distant between 400 and 500 miles, would obtrude, and knowing some of the roads had been closed already two or three weeks, I could not calculate how long I might be detained in so lonely a region, away from every one I knew. I rang the bell, and asked if the coachman and guard were going on with the bags; and was informed that they were just then about to proceed on horseback. I asked if I might accompany them, and was answered in the affirmative; not without some doubts as to the probability of my doing so. I looked out-the snow was falling fast in large flakes; it was about midnight, and our excursion through the mountains of Cumberland, which I had only heard of through the magnifying qualities of the tourist, seemed anything but pleasant; nevertheless, I thought I had been out in worse weather, and there appeared no more danger's or disagreeables for me than for the men. I therefore gave instructions for my portmanteau, and a small hamper of genuine mountain-dew, which the host at Edinburgh had kindly procured for me, to be forwarded as soon as the road was open, according to the direction; and requested, at the same time, a saddle might be put for me on one of the horses. Then tossing off' a glass of whiskytoddy, I took leave of the Scotch damsel; and, mounting a groggy, stale old animal, a pet of the Scotch coachman, who was not well pleased at my warming him up a little with the ash-plant I always carried with me, we commenced a two-and-twenty miles stage.

Such travelling would perhaps be scarcely worth recording; but it bore such a novel appearance to me at 


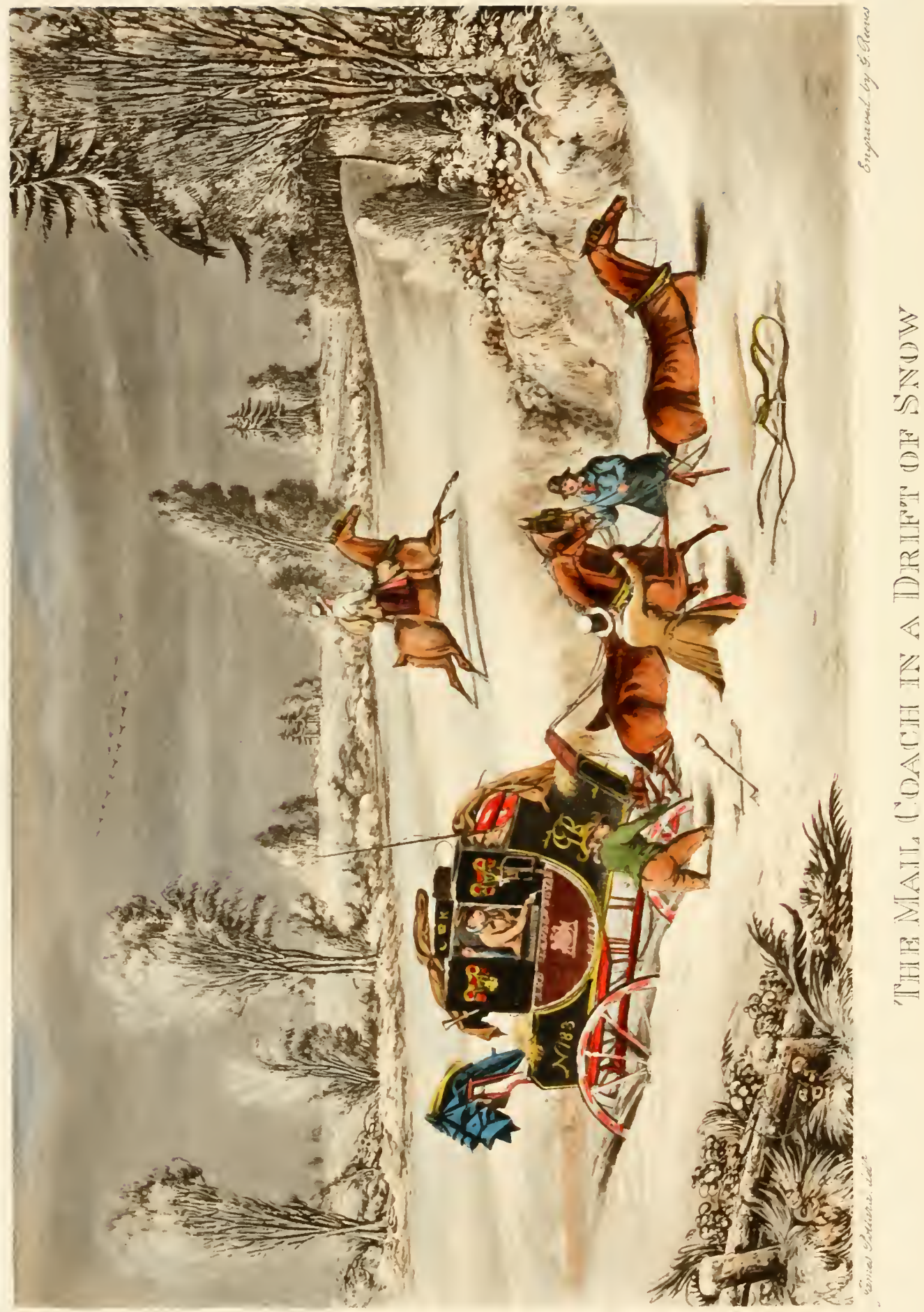


the time, the country too being altogether so strange, I could not help afterwards clothing it in my memory with rather an odd-coloured robe, and considering it as approaching to a romantic adventure.

The road seemed to lay chiefly in a valley, now and then crossing a little stream, that wound between the hills, and the snow having drifted, it required the utmost caution to prevent the animal I rode from floundering or falling in the snow, as he was continually plunging up to his girth. After proceeding about seren miles, where the silence of the night was only broken by the occasional discharge of a fowling-piece, suggesting the retreat of the French in the wilds of Russia and Poland that occurred in the previous winter, we observed the down mail, with only a small part of the roof visible, the other portion being completely covered with snow.

Three miles farther we turned out of the road to an inn, or farm-house, where my two companions refreshed themselves with whisky, in which I joined them, to drown all animosity that had arisen about the illtreatment the superb animal that had been placed at my service had received at my hands.

On remounting, the falling of snow, which had fallen in great quantities, began to abate, and shortly after, the weather clearing up, the moon, which was at the full, shone forth with a beautiful soft light, to which the snowcovered hills and dales served as strong reflectors. Arriving at Langholm, a distance of, as I said before, twenty-two miles, the guard ordered a post-chaise and four to Longtown, where, when we changed horses, 
we found the road perfectly clear and hard, no snow having fallen there.

Anxious to get to Carlisle in time for the mail to Liverpool, I promised the boys a crown a piece if they could accomplish that object; this they did to a minute, and, giving them the promised reward, I got into the mail, after hastily swallowing a cup of hot coffee.

A long day's ride, tedious indeed to me, brought us to Liverpool at half-past three the following morning; and, knowing the coach for London, of which my father was part proprietor, left at six, I did not take my clothes off', but lay down for an hour or two. Sleep I could not; and therefore, directed by the boots, I got up and walked to the "Saracen's Head," in Dale Street. It wanting an hour to the time of the coach's starting, I inquired of the book-keeper what room there was, and on his telling me there was a vacancy for one, I desired him to put my name down. On informing him who I was, he immediately sent for his master, as he was sure he would be extremely angry if he knew I had been in Liverpool and he had not seen me.

This Mr. Bretherton was a gentleman of a much higher standard than country proprietor's attained generally. He was highly connected in this large commercial townindeed, he has since risen to considerable wealth and importance in it; and I could but feel myself flattered with this mark of attention. He pressed me rery hard to stop a day with him, but I was so bent on getting home as speedily as possible, that I politely declined; and, after half-an-hour's chat, chiefly on business affair's, I took my leave of him, and got into the coach. 
My companions were a gentleman and his two daughters, from the IVest Indies, one of whom carried a parrot, and the other a small monkey, in their respective laps. With this company was I doomed to sit, cramped up, as it were, in a band-box, two long days and a night - for we did not arrive in London till seven the next evening-and glad was I to have got thus far on my journey homeward.

After stopping the following day in London, I proceeded by the night-coach to Horndean, from whence I had to walk a mile up a narrow lane, into which the snow had drifted, and had become frozen in places, so that this became really the most dangerous part of my long and arduous journey; for, falling up to my shoulders in the drift, I was only extricated by some labouring men who were going early to their work. Thus I accomplished my task-that is, had travelled nearly 1,100 miles in eleven days, and had been up seven nights out of the eleren-a feat not very common in such an unpleasant season.

This long frost, which lasted thirteen weeks, and did not break up till the last day in March, was followed by a delightful spring and summer, which gave additional enjoyment to the festivities and rejoicings that took place all over the kingdom, in consequence of the successful termination of the longest and most expensive war in which the country had ever been engaged. Joy seemed to be lit up in every countenance; and the continual arrival of soldiers and sailors from foreign stations, with the sudden revival of commerce, caused such an increase of travelling, that conveyances could scarcely be found, or 
sufficient accommodation afforded, to the numerous visitors and pleasure-seekers at the different watering places and towns of fashionable resort.

All this was most beneficial to my father's extensive concern; but he had already found, or fancied he had found, the management of such a business beyond his capacity. This, added to an attack of illness, arising principally from too great anxiety, and the vexation he had already experienced from the combined opposition of the other London proprietors, some of whom were glad to join the unprincipled man my father's money had released from his difficulties-induced him, very injudiciously, to take in a partner.

This was the first step in the wrong direction; for no good could possibly ensue from his making orer one-half of what was then just becoming remunerative to a person without capital, whose principal recommendation was the power he possessed of effecting a reconciliation between my father and the man who had already caused him so much injury.

This was done, and things went on swimmingly for a time, shortly after which death called away that archenemy of our family; and my father's disposition may be judged of, when he was induced by his partner to follow his remains to the grave.

I need not pursue my parent's unfortunate career any more than to state that this ill-assorted partnership lasted but eighteen months, when the per'son my father put such faith in, cunning in his generation, withdrew, having reaped the benefit of two summers, when the business was most lucrative, to one winter, when it was least so; 
and on the opening of the following spring, tired, distressed, and broken down in mind almost, my father parted. with this extensive concern at a great sacrifice, to those who have since built upon his ruin an immense fortune. Such are the vicissitudes of life! Had he retained possession but a little longer, Govermment, that is, the Commissioners of Woods and Forests, would have bought, as they did buy, the premises, and he would have reaped the benefit as well from that as from the large sums received by the principal London proprietors on the first introduction of railroads; and by this, if by no other means, he would have been enabled to have saved himself from that ruin which ultimately orertook him.

I was still in prosperous circumstances, and, being fond of outdoor exercise and employment, took a small farm, to which was attached a large tract of land, which was allotted to the owner by the Commissioners for enclosing the Bere Forest-and this was the first step I took in the wrong direction, involving as it did a considerable outlay of capital, which might have been employed in a more profitable direction.

Nevertheless, it gave me a strong relish and a farther opportunity of indulging in the sports of the field, and was a more general introduction to the yeomanry and gentry of the county, as I still constantly hunted with the Hambledon, and sometimes with the Hampshire hounds. Here I cannot help relating a most ludicrous incident I witnessed.

The master of the Hambledon hounds at that time, however strange it may appear, was a wealthy Dutch Jew, partaking rery much of the Dutch style of build, being stout, thick, and round, as his mind did of the 
peculiar propensities of our people, as the following anecdote will show :-

Giving a dinner one day to the neighbouring gentry, at which he made a great display, "according to the custom of the Jews," one of his guests, the master of the H.H. ${ }^{1}$ than whom a better sportsman, or a kinder master or a gentleman more respected never lived in the county, accidentally broke a beautiful china dessert plate. This was not unobserved by the host, who said, in his broken dialect, -

"Got plesh my soul, every roun of dose plates cost me a guinea!"

Whereupon the offender put his hand in his pocket, and taking out a coin of that value, jauntingly threw it towards the head of the table. The company expressed their surprise by their looks, but they did more by their smiles when they saw their lost quietly take it up and put it in his pocket !

As he lived in a mansion adjoining the Hampshire country, he sometimes hunted with them on the alternate day with his own. One morning, when the former met at Beworth Cross-roads, finding a fox in Thorley Wood, always a certain find, we ran him to Blackhouse, where we came to a check. The Dutch gentleman and others were quietly seated on their horses, not smoking their cigars, as is now so much the fashion, but waiting the effects of a cast that the master was making - a scientific acquirement necessary to the proper understanding of this noble sport, in which he excelled-when suddenly the hounds, hitting off the scent together, gave forth that 
exhilarating music which to be appreciated must be heard in the field.

Away went the horses, but not all their riders, for our friend, the Jew, was caught up like Absalom, in the tree under which he was sitting, while his horse went clean from under him; and presently, after gesticulating and howling, down dropped this scarlet bundle of oddities, like an over-ripened apple, demonstrating, as Newton's did, the centre of gravity as he came on a moist spot of his mother-earth; while his companions, galloping away, had only time to look back on their saddles, and smile at the very ludicrous appearance he made.

Upon another occasion, when, after a sharp run, we had killed our fox in a farm-yard, near Droxford, and stood waiting the arrival of the master of the pack, he came trotting in at the gate with his habitual smile, when, in endeavouring to cross the yard, his horse suddenly sank up to the girth in the straw that covered lightly the manure. The more the animal plunged the deeper he went in the mire, when the alarmed Jew-supposing he was going to the bottomless pit, and the disposal of his ill-gotten wealth occurring to him at the same time -exclaimed with extended arms and terror-stricken visage,-

"My vife, my vife! I leave all to my vife!"

Many other ludicrous feats I could recount of this redoubtable follower of Nimrod, who was the laughingstock of the county-but let the above suffice.

The sudden appearance of this strange gentleman, in one of the first mansions in the county, was a mystery; his antecedents were not known, and the manner in which 
he became possessed of so much wealth was a secret-a secret which is ever held most sacred by the children of Abraham.

It was, however, generally reported and believed, that when the great Napoleon's star was approaching its apogee, this gentleman was employed by that military chief to levy contributions on the inhabitants of Belgium and Holland, and upon the sudden and successful outbreak of Orange Boren, that caused the man who had trodden upon the laws and liberties of the Batavian Republic to retire behind the Rhine, the Jew had not an opportunity of discharging his duties to a fallen Government ; and thinking that both his person and his property, consisting of the money he had thus borrowed of his countrymen, would be safer under British protection, he wisely crossed the channel, knowing that no questions would be asked as to the means he employed to become the possessor of that which all classes here so derotedly worship.

But to the praise of this gentleman it must be recorded that he kept a good house and gave sumptuous entertainments, taking occasion to observe to his guests, as his daughter's one after the other left the dining-room, "Dare goes dirty dousand pounds-dare goes dirty dousand more; "and, notwithstanding all these oddities, was most kind and charitable to the poor of the parishes of Westzneon and Warnford, among whom his name will long be remembered.

It will not be difficult for the reader to understand how the first four year's of my married life were passed. In the full enjoyment of health, as well as domestic comfort and 
happiness, moving in good society, and with a business hitherto lucrative, to which I gave all the attention I could, the love of field-sports did but little, if at all, interfere with it: I could not control, though I partly foresaw, the circumstances that accomplished my fall from a position I had held with credit, and in which I had gained the good will and esteem of those who had known me both abroad and at home.

Among the persons who came within the circle of my acquaintance, but with whom I was not on terms of intimacy, was one of rather strange appearance. He possessed very soft and, to some, pleasing, but by no means polished, manners, and always addressed every one with a smile.

Now, I myself experienced no wrong from this person; and though I was his stepping-stone to fortune, it is not for me to judge how he was enabled to take that step. The first time I saw him, when he was not in very good odour with his fortune or his friends, was in a bookseller's shop I frequented. On one occasion, a stranger-a traveller, I suppose-came in, and, eyeing this gentleman as he made his exit, asked his name. On being told-

"Ah, I thought so," he said ; "I thought I remembered him as one of eleven that ran away from a school at Durham, and, out of the eleven, seven have been hung."

This might have been a little jeu d'esprit of the stranger's, but I do not forget it; for he was a North countryman, and might have fallen under the designation of a Yorkshire tyke, had he not had more lofty aspirations ; neither did I forget his habitual smile, which gained for him in the betting-ring the soubriquet of "Silky," and 
which I always call to mind when I reflect on a maxim I afterwards found in my journey through life to be correct: "The man who always laughs or smiles is a fool; -the man who never laughs nor smiles is a misanthrope: but he who always smiles and never laughs is a deep, crafty, designing person."

With this gentleman was I induced to join in a contract to do the horsework in the dockyard at Portsmouth. At the time he was clerk, at a small salary, to the then contractors, who, with the hopes of getting more money, had given notice to the Government of their intention to better their position, little supposing their own servant was going to supplant them. Of this I knew nothing, and perhaps considered as little. as I was too glad to entertain a project that, if well carried out, would make up for that deficiency in my revenue likely to accrue from a too speedy falling off in my own legitimate business, which the peace and the competition for public favour, in establishing faster and more expensive conveyances, was likely to bring about.

The escape of the ex-Emperor from Elba had renewed the war, and raised the hopes of those who, like myself, anticipated a further benefit from it, but these the decisive battle of Waterloo now rendered illusory; and I thought I was taking a step in the right direction when I acceded to the proposal made me, which was to put in a tender at the Nary Office, Somerset House, for the supply of 140 horses, to do the work in the dockyard, at a certain sum per team of four horses and a man per diem.

Now, my intended partner did no discredit to his birth- 
place or his bringing up; for, like his countrymen, he was a man of shrewd intellect and keen perception, my senior in age by eleven or twelve years, and had made his calculations on such a scale as almost to ensure the reception of our tender, as well as to avoid the great error of being below what might be, indeed, what was a remunerative price.

Accordingly we attended at Somerset House on the day and hour appointed, which was two o'clock in the afternoon. We spent the morning, I remember, in going to Whitechapel, and seeking out what was a great object of interest and curiosity-that is, the birth-place of Matthew, Mark, Luke, and John, four infants of whom a poor woman had recently been delivered.

We had not been in attendance a quarter of an hour before my name was called by the messenger, who escorted me to the room where the Commissioners were assembled. After a few questions, which I answered to their satisfaction, I named tivo bondsmen, of whom my father was one, and the contract was mine, and mine alone; for they would hear nothing of any second person-I must take it entirely on my own responsibility.

When I retired, and reported the result of my interview to my friend, he was a little disconcerted; but on my assuring him that I could and should still fulfil my agreement, he professed to be satisfied.

We afterwards dined with my father, who wished us joy of our bargain, and drank success to its result. In about six weeks we entered on our contract, I transacting all the business with the dockyard officials, while he superintended the supply of provender for the horses. 
This brought me in frequent personal communication with the excellent officer who so long held the office of Commissioner, and performed all its duties with a dignity that sometimes astonished the subordinates, but at the same time with solid advantage to the country.

His religious views were not quite consonant with the doctrines of the talented and truly orthodox preacher who occupied the pulpit in the dockyard chapel; and their dispositions were neither of them sufficiently pliable to prevent now and then an outbreak or unseemly altercation, which, to the best of my belief, terminated in the resignation of the reverend gentleman.

It was many year's after this, when, accompanied on the box by a minister of the Crown, and a near relative of the distinguished officer I have been speaking of, that the conversation turning on nautical subjects, I named many officer's of high rank and distinction, and my right honourable companion asked me if I had ever been acquainted with the Commissioner of Portsmouth dockyard, and requested to hear what I knew of him.

I stated, in reply, that I had known him many year's; and described him as in person of a very commanding appearance, remarkably upright in his carriage-which is not very common with those of the most aristocratic birth, who have spent their youth on board ship-with rather an austere expression of countenance. I said that his manner to those who did not know him would be, indeed was, set down as haughty in the extreme; and that though I always found him affable and polite, it was reported that he carried a brace of loaded pistols about with him, in his breast pocket. 
"Indeed!" said the Secretary to the Treasury, for such he was; " for what purpose, in God's name, did be do that?"

"To shoot the first man he met prouder than himself," I replied.

At this he smiled complacently, assuring me that he should certainly take the first opportunity of making known to the Commissioner the information he had thus acquired. 


\section{CHAPTER X}

REVERSE OF FORTUNE

A Wet Season-Beneficial Farming-A Racing Stud-A Commissary -Petworth-Duke of Somerset-Seymour the Painter-Scene in a Brook-An Alarming Purchase-Contagion-PathologyNaval Captain-Domestic Calamity-Alterations and Improvements-An Unblushing Villain-Driving Clubs-A SatumaliaComparison-An Attraction-A Final Resolution.

I wouLd willingly draw a veil over this part of my history, for it brings to my memory many circumstances of a sorrowful nature, as well as an accumulation of losses of no ordinary occurrence, though at the risk of being accused of possessing a mock or morbid sensibility; but as it is necessary to connect my former life with the character I have assumed in the title-page, I shall proceed, however reluctantly, to give it a place in this narrative.

Some of my readers will be able to call to mind the disastrous year of 1816 , more particularly those engaged in agricultural pursuits. This, it may be remembered, was a very wet season, so much so, that in some parts of the country the harvest was not gathered in till October or November, and I have since heard from undoubted authority that beans were standing in the field at Christmas. 
Now, I have before related that I had hired a farm, of not very large dimensions, certainly about 120 acres, to which was attached 200 acres of unbroke land, consisting chiefly of forest. The timber, with the expense of cutting it, was the landlord's, but clearing the land of the moors or roots and getting it in order for cultivation was the tenant's.

Thus, what with grubbing, clearing, chalking, and well manuring, I had laid out half the value of the fee-simple of the land, when my first crop of wheat, which bid fair to remunerate me in a great measure for all my outlay, was beaten down from its weight by incessant rains, and became mildewed, blighted, and germinated.

The first shower fell, I remember, on Midsummer Day, up to which time the weather had been remarkably fine, and scarcely a day passed after, up to Michaelmas, without rain. My clover and grass crops were already for the most part in swarth, and after repeated attempts to cart, and the people constantly on the watch to take advantage of the least appearance of sunshine, all our endeavours to stack the clover were fruitless, and we were obliged to draw it into the yard to make room for the second crop, which had already begun to peer above its drenched predecessor-reminding one of the Frenchman in the late Charles Matthew's comic tale, "whose hair grew a little above his hat."

My wheat I did not gather till the last week in September, and that not till after a long and expensive time, with all my Lent corn, in the damaged condition I have stated.

We had had a most propitious spring-everything 
looked well on the farm, the crops of corn most luxuriant, and the cattle-sheep I had but few, having no summer food-in a thriving condition: among them three thoroughbred mares, two by Haphazard, the other by Buzzard, and a splendid grey two-years-old colt, by Evander, which, with another yearling colt, by Trophonius, entered in a hundred guinea sweepstake at Goodwood, I had purchased at Tattersall's, all having been the property of a deceased trainer and owner.

These all, as if by a fatality, fell one after the other in this same autumn. The grey, for which I had been offered \&200, staked himself in trying to jump the palings of a lonely homestall. One mare broke her leg in leaping into the road at the sound of a postman's horn ; the other, who would never take to her foal, kicked over the stallpost in the stable and was killed; and the colt that I had

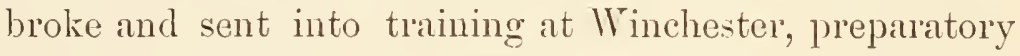
to his engagement at Goodwood, for which he would have walked over, died of inflammation.

My partner in this affair was a gentleman of considerable notoriety, who, after having gone through the Peninsular War as Commissary to the forces commanded by the great Duke-acting also as master of a pack of hounds kept for the amusement of the officer's when the army was enclosed within the lines of Torres Vedras-had purchased a small property in the immediate neighbourhood of the farm I occupied. As our dispositions were alike in regard to the pleasures of a country life and our love for the animal creation, we were on the best of terms; and though the irritability of his temper, and his love of command, contracted in his long military career, would 
sometimes cause me to suppress a laugh, when he came in contact with the simple habits of the farmer, or the rude manners of the labourer, his conversation and general deportment had a charm that chained me to his side. He was highly connected, and had married the sister of my landlord, the owner of Southwick Park, and the more than 20,000 acres that surrounded it, and had commended himself to the tenantry by the introduction of a Spanish boar, that has been the means of a great improvement in the porcine breed in that vicinity, and has tended as much to immortalize the name of William Gauntlett, Esq., as has his arduous serrices in the war in Portugal and Spain.

Thus did my agricultural investment receive a deadly blow from the effects of this unpropitious season, which was most severely felt by others besides myself; and thus was my injudicious speculation in blood-stock blighted in the bud; and though my practice was but short, experience has since led me to believe that the breeding and rearing such expensive animals is incompatible with the more legitimate pursuits of the practical farmer.

In the first place, it is very rare any tract of land, whether 100 or 1,000 acres, long cultivated or recently enclosed, set out for the growth of corn or the grazing of cattle, has the convenience necessary to be set apart from the rest of the farm for their support, with space enongh for their daily exercise; and, in the second place, it is equally rare to find men among agricultural labourers upon whom you can rely for the care and attention that racing stock, at all seasons and at every age, require. Indeed, it seems to me to be a pursuit more fit and 
intended for, those noblemen and gentlemen who, besides their love of the animal, have ample domains, which they can divide and subdivide into small paddocks, adapted for either sex and all ages, and who can afford to employ men of character and judgment in their rearing and training. It is a profession of itself, and requires skill and experience, with "all appliances and means to boot," to attain to an eminence in it-assuming fame, and not profit, to be the object.

Establishments comprising every capability for carrying out this rational and national amusement are scattered over the country, and are to be found in almost every county in England; but, for a regular organized system of management, and for every arrangement and convenience for the breeding, rearing: and training the racehorse, few could come up to, and none could surpass, that of the late Earl of Egremont, at Petworth.

The diversity of the soil was well calculated for every stage in the growth of this valuable animal. The rich pastures of the water-meadows gare ample nourishment to the suckling. while the dry. sandy nature of the adjacent lands, corered with a soft, verdant turf, with a small stream of clear water running through it, was well adapted for the prerention of too great an expansion of the foot, which a maturally wet soil will frequently produce; and, from its extent, gave full scope for the frolicsome and voluntary exercise of the yearling, where he could fairly derelop his quality of speed, and where, from the whole produce, the noble owner selected such as his own excellent judgment pointed out, to enter for the great prizes at Epsom, Newmarket, and elsewhere. 
Paddocks, furnished with well-constructed sheds, for the reception of two, or three at most, colts or fillies, when rising two years old, were enclosed with brick or flint walls; each paddock had its attendant, to feed and water his own particular charge; which then, when fairly handled and broke, was sent to the training stables on the Downs, where the animal was prepared to become a candidate for those great prizes so many of his lordship's horses carried away. It is only by such management and by such means, joined with a perfect knowledge of the properties of particular breeds, and first-rate judgment in selecting that with which to cross and improve his own, that any man can command a flourishing racing stud; and this falls to the lot of but few.

This magnificent establishment, so worthy alike of its purpose and its noble owner, was founded or commenced more than a century since by "the proud Duke of Somerset," as he is termed, in contradistinction to the first of his family, the virtuous, talented, and popular, but unfortunate Protector, who deserved the title of Greatand descended with the mansion and estate to the late proprietor, who presided over it with so much benefit to the turf and to the nation. It has long since become extinct as a first-rate racing stable, and the stud dispersed all over the kingdom; but the blood of old Gohanah still runs in the veins of the most celebrated horses of the present day.

I cannot forbear relating an anecdote here of that haughty old nobleman, the Duke, though the reader may say, what has this to do with stage-coaches? But, as the incident occurred at the princely mansion I have had 
occasion to mention, and as the place, though not the time, comes within my early reminiscences, it will not be travelling far out of the record, as the lawyers say, to give it a place here.

The lordly owner of this splendid domain, and master of one of the finest racing studs in the kingdom, sent for Seymour, the celebrated animal painter of that day (some of whose best productions I have been till recently possessed of, they having been given me by my father), to take portraits of his most celebrated horses, with which to adorn his gallery. The Duke entertained the artist with condescending hospitality, and one day after dimner, filling his glass and turning to his guest, said, in a halffamiliar, half-sneering manner,-

"Cousin Seymour, your health."

"I thank your Grace," said the painter, "but I have more claims to that appellation than you are aware of."

The proud peer immediately rose from his seat and left the room. In a few minutes the steward entered, with a demand from the Duke to know from the artist the amount of his charge, which, upon stating, the steward immediately discharged, saying at the same time there was no further necessity for his remaining at Petworth. The Duke then employed another artist of almost equal celebrity to finish what Seymour had begun, who, soon feeling the inferiority of his own talent, candidly told the Duke that no one could do this but the original artist. Upon this the Duke wrote to Seymour, inviting him to resume his professional occupation at Petworth. He replied, in a short note, "To prove I am one of your Grace's blood-I shall not come." 
When I took the dockyard contract, in conjunction with the person I have before spoken of, we thought it best for each to provide his moiety of the number of horses required, as we could not agree with the late contractors about the purchase of their stock; consequently, I went to the different fairs to buy whatever desirable animals might happen to be in the market. At one of these-Rumsey-my friend and I had been together; and here an incident occurred, of a serioludicrous nature, which I cannot help recording. After dining at the ordinary with farmers, horsedealers, innkeepers, \&c., \&c., I proposed driving to Stockbridge, that is, to the stables of old John Day, grandfather of the wellknown trainer of this name-the place is now, I believe, called Danesbury - as I had a horse there in training that was about to run at our garrison races.

Accordingly, we started in the evening, and, in passing through the water that crosses the road at Somborne, overtook two "gents," whom we remembered to have seen imbibing considerably at the White Horse, at Rumsey. They suddenly stopped to allow their horses to drink. In passing, the step of my gig just touched the wheel of theirs, when, from the slight collision, the gent on the driving side - a very corpulent man-tumbled out, headforemost, into the little stream.

My companion said not a word; nor did I, but kept on at a good pace, which I afterwards-upon his looking round and saying, "They are coming at a full gallop"improved. We had just gained the top of a hill, where the declining sun shone directly on the chalk that had been excavated in the bank, when my horse suddenly 
threw up his head, staggered, and stopped. There was no help for it; he was taken with the meagrums.

On came this Falstaff, bursting with rage; and, in passing, shook his fist at us, and his wet, but not "gory Jocks"-at which I could not help smiling, though his threatening action was accompanied with most abusive ter'ms.

"Don't you know who that is?" said my friend.

"Oh, yes," said I, "I know him; he keeps the Royal Hotel at Stockbridge, and he means mischief, I see."

We were not then more than a mile from Stockbridge; and, after getting out and pricking my horse in the roof of his mouth with a penknife, he recorered and we proceeded. On our entrance into Stockbridge, where the road is very wide, we perceived the gentleman in front of his house, a posse of ostlers and stablemen with him, standing in the middle of the road, with the evident intention of impeding. our further progress.

"Stop him, Will! take hold of his horse's head, Harry!" rociferated the master; for the drenching had not cooled his rage or quite drowned the effects of his potations.

Pretending surprise at such an interruption and a total ignorance of the cause of it, I indignantly told him, calling him by name, that he had committed a breach of the law, by stopping me on the King's highway, for which I should, most certainly, call him to an account before a proper tribunal; adding, that if he had anything to say to me, and could conduct himself decently, I was going but a very little way farther-he would find me at Mr. Day's. 
"Let go my horse's head, sir," said I. addressing myself to the ostler; this the fellow instantly did, and, just touching him with the whip, we were soon under Mr. Day's hospitable roof, where I always had a hearty welcome.

We had scarcely discussed a good erening's meal, at which I always substituted malt liquor for the lighter and more polite beverage-and my excellent host's homebrewed was of the best quality, and recommended itself strongly to my not very elevated taste-when the subject of our, or rather my, laughter came in. I saw instantly that he was another man; my coolness and self-possession had subdued him. Seeing me, too, a welcome guest at the house of his neighbour and friend, he found reason to alter his tone.

He addressed me by name, which he had learned in the interim, and said he was sorry he had stopped me; adding that had he known my name, or where I was going to, he should not have done so; but he considered himself very unhandsomely dealt with by my rumning against him and causing his ejectment into the purling brook.

I attempted an explanation, pleading ignorance, and attributing the accident to the effects of Rumsey Fair, and the excellent port of mine host of the "White Horse." After a little further argument or altercation, our friend Day interfered, and proposed our shaking hands and drowning all animosity in a bottle of the best his cellar could afford. This was speedily put on the table, and on the angry Boniface had the desired effect.

But this comic interlude preceded a very serious afterpiece. 
At one of these fair's-Stow-in the Wold in Gloucestershire, our time growing very short, I was induced to buy a mare, at rather an inferior price, of a man whom I knew to be as big a scoundrel as the fraternity could produce, but I did not at all suspect the piece of villany that had been practised on me. Arrived within nine miles of home, the mare showed some very suspicious symptoms - so much so, that I dare not send her into the dockyard, as all horses had to pass the inspection of a man appointed by Gorernment before they were admitted; and, for my own credit's sake, I would not risk this. Had I had her destroyed at once, I should have been spared the ruin that at no distance of time overtook me. I rery foolishly sent her to my own private stables, and kept her two or three days: when such unmistakable proofs of that dire disease, the glanders, manifested themselves, that I had her killed.

Every precaution was taken, as far as cleansing, whitewashing, and fumigating the stable went, to prevent its spreading, as I well knew what a virulent, as well as what a contagious disease it was; and the summer of that year passed away without any appearance among my other horses of anything like infection. Indeed, I did not occupy this particular stall till the hunting season had commenced, and it was not till Norember that this alarming disorder reappeared.

I went to meet the Hambledon hounds upon as good a hunter as ever went into a field; but on its coming on wet, I altered my mind, and rode to the village of Hambledon. On meeting with a farmer I knew, he asked me hor it was that I was not with the hounds. 
I told him I was too late; for they had found a fox and gone away.

After looking at my horse some little time, he said, "It is a good job you were too late, for your nag has a serere cold ; see how he discharges at the nostrils."

I thought the animal had not shown his usual spirit, and, after stopping half an hour, I rode him gently home, and treated him according to the directions of the experienced hand I had met in the morning. He got no better, and in a few days alarming symptoms began to show themselres-so much so, that I wrote to a very noted reterinary surgeon at Salisbury. I had long known him, as he and his father had been engaged with my father in the coach business, and he had been rery judiciously placed at the college in London, where he had, some time before, passed an examination with very great credit.

He came by the mail in the morning, and, after examining the horse, pronounced his disease to be the glanders, of the most malignant description. I need not add that the animal was led out and immediately killed -an operation that my friend most skilfully performed, by inserting his knife between, and a little behind, his ears, thereby causing almost instant death.

Thus, reader, have I been perhaps tediously explicit in relating the commencement of a malady, or I may say plague, that ravaged my stables, and caused, in the course of a few months, a loss of 120 horses, the greater part of them young and valuable animals; and this, added to my other losses on the farm, was enough, comparatively speaking, "to break a royal merchant down." 
Truly might I quote from that beautiful poem some of us were taught to lisp in our childhood,--

"My cattle died, and blighted was my corn."

When I look back to this sad calamity that accomplished the ruin from which I nerer recovered, and that altogether led to the change in my position that afterwards followed, I am led to ask, "How is it that little or no advance or improvement has been made in the veterinary art? While we read of discoveries in other sciences, some of which are made patent to our senses, we find none in Pathology that would lead to the successful treatment of a disease which has proved most destructive to the noblest and most useful animal in the creation, although it has excited the study and attention of firstrate practitioners, both here and on the continent, for now more than 100 years. Nay, even the seat of the disease has never been properly defined-stomach, lungs, and head, have each been pronounced as such, by different professor's of this most useful art; but dissection after dissection has failed to trace the source of this bane to the animal's existence.

In the absence of all cure, then, and in despair of finding any antidote, how necessary is it to use every precaution to guard against its appearance; and this I cannot more forcibly recommend than in the words of a distinguished and most excellent naval officer, ${ }^{1}$ whose custom it was to hang on his cabin-door, every night before retiring to rest, his own written instructions for the guidance of the officer of the watch. I need not say they

${ }^{1}$ The late Admiral Sir Joseph Sidney Yorke. 
varied with circumstances, and were generally written in that jocular spirit that would be justly appreciated by officers, with whom he always lived on the best of terms :-

"All physicians, from Hippocrates and Galen, down to the learned and celebrated Dr. Eady, have decided that prevention is better than cure. Keep a d- good look out-do!"

Lofty and well-ventilated stables, that should not be crowded, and particular attention directed to the animals' diet being sweet and wholesome; with good grooming, in which care against the horses taking cold should be included, as well as cleanliness in all stable utensils, will mainly contribute to that desirable end, and will prevent any predisposition of the system's imbibing the germ of this insidious disorder. It sometimes commences with farcy, a disease almost as fatal. Always remember that the first loss is best, and death is the only prevention of contagion.

How frequently have I witnessed the injurious effects of a wretched and parsimonious economy in the purchase of inferior corn. Diabetes, inflammation of the kidneys, acrid humours, general debility, and other diseases, all arising from cheap or stale oats, frequently terminate in farcy or glanders.

As an instance of the virulent as well as dangerous nature of this disease, even to the human subject, I remember a man employed as a knacker, inoculating himself while in the act of flaying a horse that fell a victim to it, and dying a few days after, in the greatest agony. 
I will merely subjoin, that strangles and influenza, to which all horses are subject, are frequently mistaken for this horrible disorder; there is a similarity certainly in the early stages, but ulcerated nostrils and the nauseous smell of the discharge are always decisive, and as soon as these are evident the animal should be destroyed. No one need wish his neighbour, be he friend or foe, who has anything to do with horses, a greater or more serious evil than the glanders.

The misfortunes with which I liad been risited, though evils of no common occurrence, were such as all men in business are subject to, and from which some have better opportunities of recovering than other's, some also can display better judgment in treating them than others: be that as it may, it pleased the Almighty about this time to visit me with a sore and heavy aftliction.

My wife had now for some time shown symptoms of a complaint, common and so fatal in this climate, that had already carried off an elder brother and sister. I have every reason to believe her death was accelerated by my reverse of fortune; but nothing, I was well assured, could arrest the enemy that had made such rapid progress in the destruction of all the organs which sustain vitality.

I shall not dwell upon this sad epoch of my life any more than to say, that after living a little more than four year's in connubial felicity, I was left with two children, the younger but eighteen months old; and after my wife's remains were interred in the vault my father had built, I had ample leisure to contemplate my desolate condition.

During the period I have been writing of, a very 


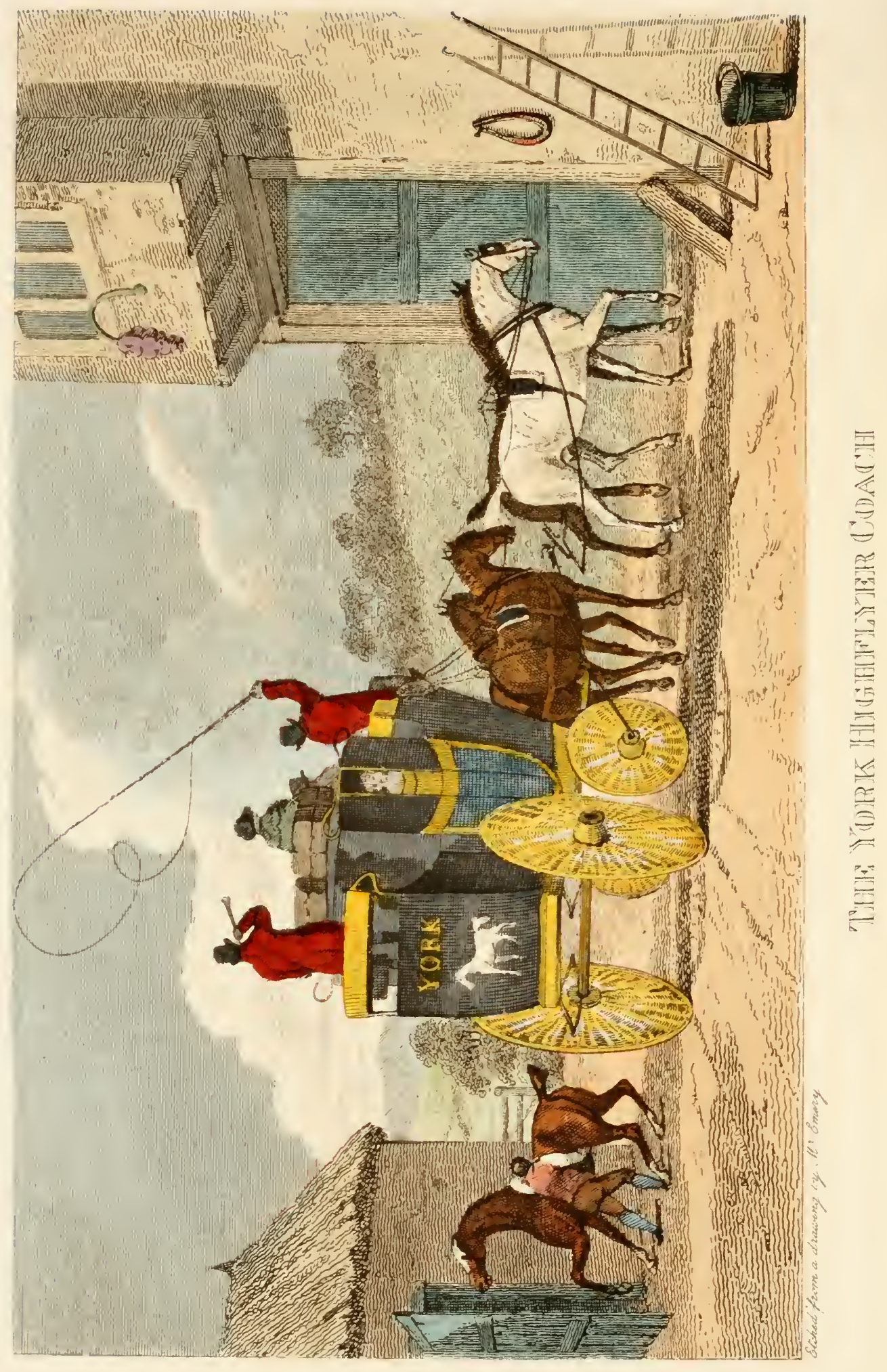


remarkable alteration and improvement had taken place in the system of stage-coach travelling. Instead of the old heavy lumbering vehicle, with the boot fixed on the foreaxle, and a large basket on the hind, with a license to carry six inside passengers and as many as could well be crowded on the outside, after repeated steps in the forward direction, the new and elegant Telegraph coaches made their appearance. With them came a change in the quality of the animals, whether biped or quadruped, attached to them.

It is with the former I have more particularly to do. Those of the original craft, sons of men who had been long known in the old school-of whom I may speak more particularly hereafter-assumed a different style of dress; and having benefited a little more by education than their fathers, could assimilate themselves better to the manners and understanding of a very different grade of travellers-while the great improvement in the pace and sort of animal required rendered the situation of the "dragsman," as he was now termed, one of enviable delight.

Consequently men of a far different class aspired to it. Yeomen left tilling their farms-military men forsook their profession - even clergymen their pulpits, to enter upon this pleasing vocation. ${ }^{1}$

These alterations and improvements began first of all

1 Some of my readers may remember the handsome military officer, Captain Proben, who officiated on the Reading coach (not Williams') for many years, who has since inherited considerable property in Gloucestershire; as they will the poor Parson Demis, who exchanged his vicarage in Berkshire for the box of the White Hart, Bath, but finished his career on the Norwich road.

VOL. I. 
on the Bath and Oxford roads. It was a little before this time that driving four-in-hand became a fashionable amusement among the more wealthy residents of the latter city and university. Siudying the rudiments of the art in a school where every facility was rendered for acquiring proficiency, and associating with some of its most respectable profestors, they soon became comoisients, as well as amateurs, and, increasing in numbers, finally resolved themselves into a club or institution, called the B.D.C., for Bedford Driving Club, but lately extinct; after which, by a handsome donation of a hundred guineas, they founded another B.D.C., or Benerolent Driving Club, which has also been defunct some little time. Both tended very much to the adrantage, and also to the respectability, of their more humble tutors in the art, and their successor's.

About this time, and out of this institution, sprang up another, termed the "Bang Cp," in accordance with the slang then much in vogue. and it reckoned among its numbers some of the most distinguished and wealthy members of the aristocracy of the day. Cavendish Square was their place of rendezrous; and here on a Sunday aftemoon might be seen assembled from twenty to thirty of the most splendid turns-out that money could buy or judgment could select.

After some little time spent in putting to and adjusting bearing-reins, coupling-reins, \&c., they would mount and drive in procession into and round Hyde Park, eliciting the surprise and admiration of the gaping multitude, which consisted of all classes and both sexes, some of whom passed judgment upon the merits of the different 


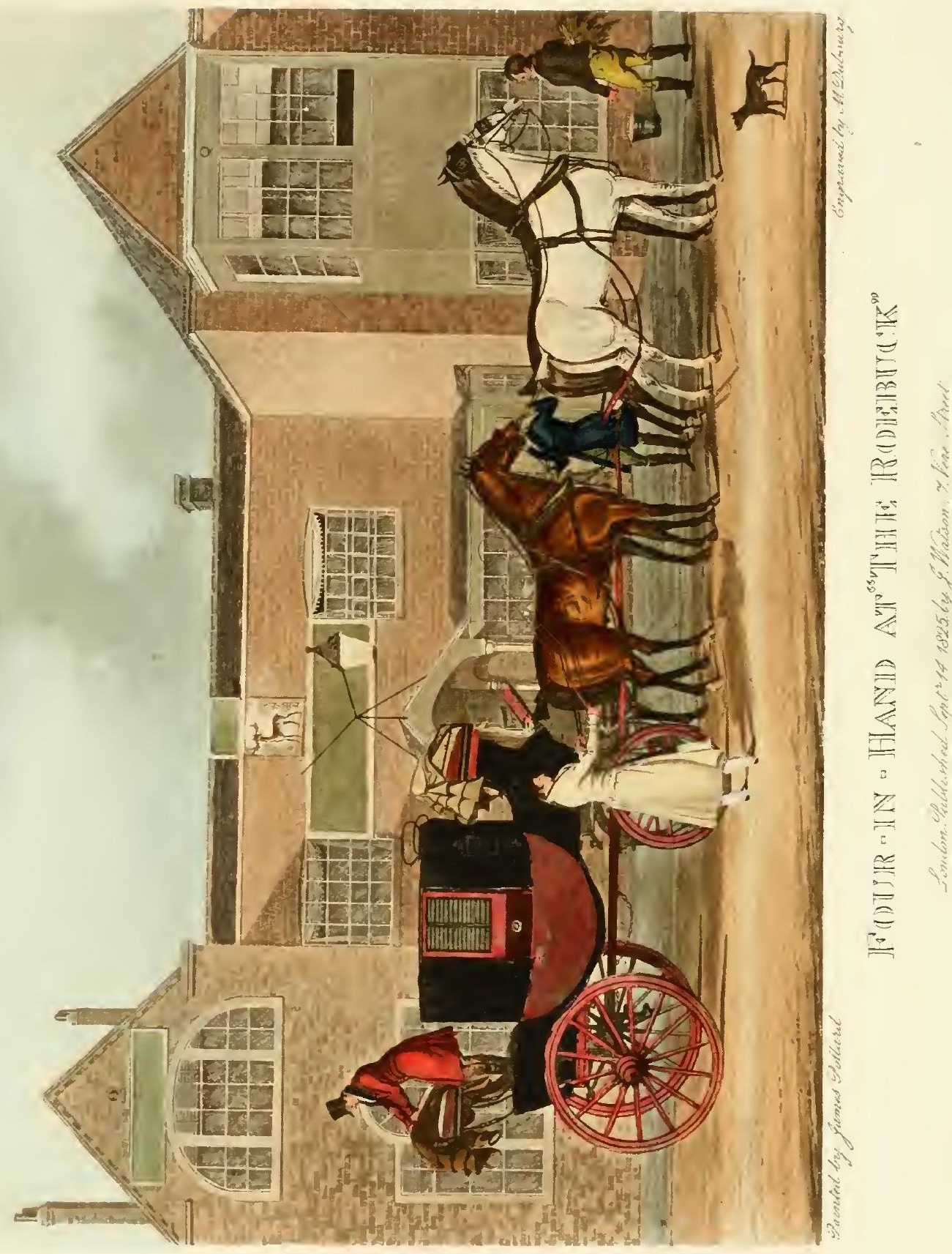



teams-their shape, make, colour, and action; others equally criticized the attitude, skill, or execution of each particular performer; while all rejoiced at so splendid an exhibition of an enjoyment purely national.

The subjoined song, which I since penned in my idle moments, and once had the honour of singing before a crowded audience, will give some idea of what the fourin-hand was :-

\author{
SONG. \\ (Tune, the "Trotting Horse.")
}

I drive the four best spicy prads of any out of town;

Well matched for size and colour too, and where's the man to frown? Their heads all up, they step along, at such a splendid rate, The pride of all the gazing throng, the enry of the great.

When I push along, dash along, there's none so good as they, All England can't produce their match, I'll bet you, play or pay.

Near thorough-bred, their action's like four rowers in a boat, So true their step, so fast their pace, so shining erery coat; A pack-thread string will hold them all, so temperate and kind; And if you only drop your hand, why, they'll outstrip the wind. As I push along, ide.

Dark chestnuts of the rarest stamp, their like was nerer seen; All young and sound, from mane to tail no blemishes between; Their harness neat, and polished bright; and then the varmint drag, Who would not boast of such a team, of such a turn-out brag?

When I push along, \&c.

Now, when all the swells, on Darby-day, to Epsom hurry down, And vie in every style of drag, who most can come it brown; No sooner on the crowded Downs, with elbows squar'd, I stop, Than nobs, professors, come around, and on their fortune drop.

When they see me push along, \&c.

Returning with our skins well lined, and chaffing's all the go,

Dukes, lords, and squires, to pass the throng try ererything they know.

Apollo's son was ne'er so proud, nor half so pleased as I,

When, dashing past a host of things, I say, "My lord, good-bye." As I push along, ile. 
Now, if the railroads, that vile foe, t' our sport should put an end, And England's pride, the four-in-hand, no longer have a friend, To some lone cot I will retire, and dream upon the past, And live again on what was once the fastest of the fast.

When I used to push along, de.

But with all this, to me there was something wanting to finish or fill up the picture. Although the four hor'ses were shown off to the best advantage that skill and judgment could produce, joined to minute attention to the appointments of both carriage and harness, still there was a nakedness about the whole affair, when contrasted with that more humble, at the same time more useful, candidate for public favour - a stage-coach-they were striving their utmost to imitate. Indeed, there was something absurd in my eye in a nobleman or gentleman sitting alone on his box, behind a splendid team that required little or no driving, with no companions to share his pleasure, envy his position, or admire his skill:-and whose expensive equipage would seem to an indifferent observer, deroted only to the enjoyment of two or more flunkeys, seated on the hinder part of the rehicle, with folded arms, surveying the beauties of the surrounding country, through which their master was conveying them so kindly, and in such a magnificent style.

It is not intended by these observations to detract from the merits, the beauty, or the utility of the accomplishment of driving four horses well, or to deny the necessity of practice in order to become a master of this manly and national art, but to show how the want of companionship would deprive the solitary votary of Jehu of half his pleasure. Compare this with the well-appointed, well-loaded stage-coach; admire, as you may, the splendid 



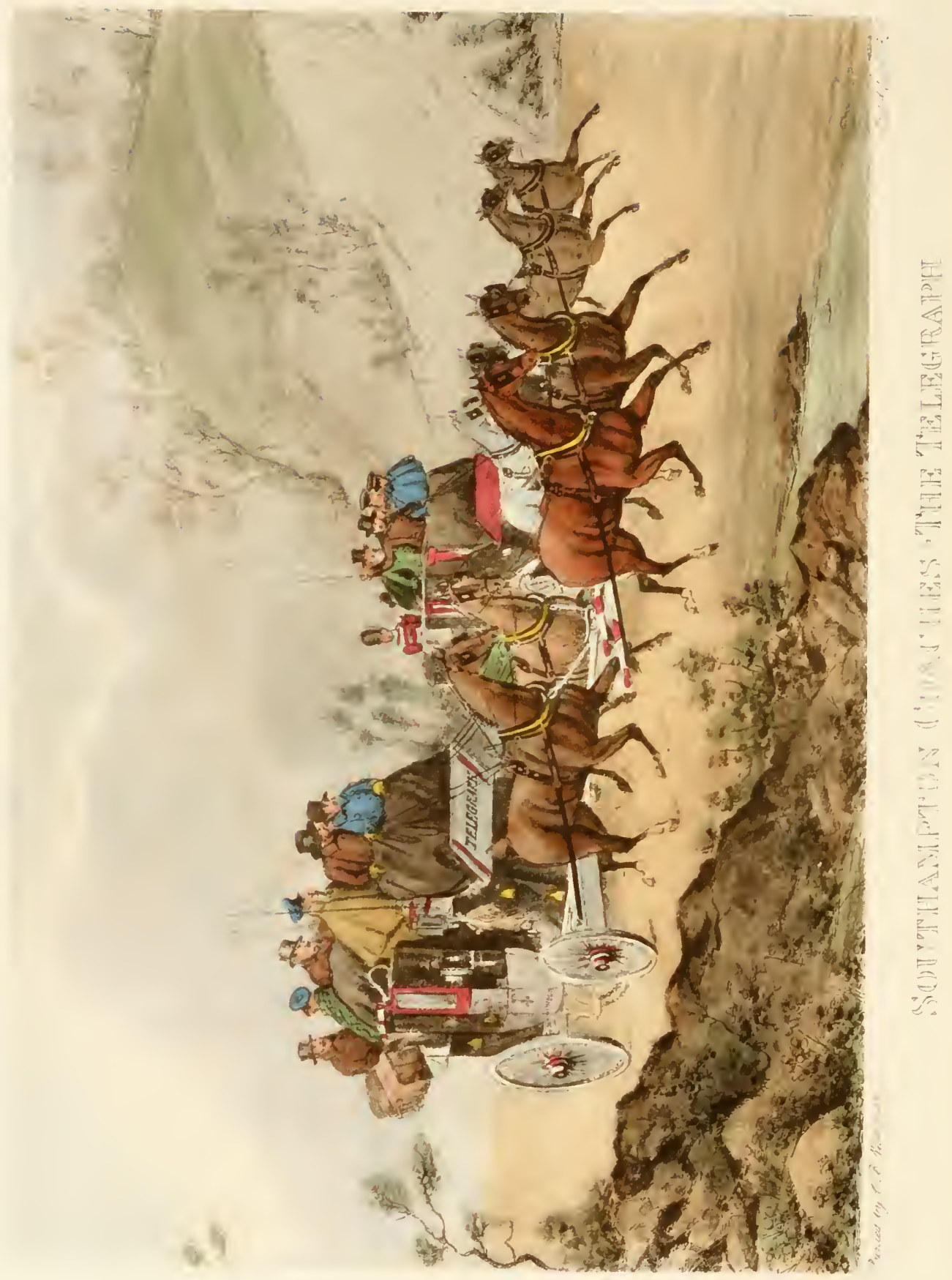


turn-out of a noble Marquis, ${ }^{1}$ who had issued with his four iron-greys from the gates of Strathfieldsaye-the seat of his illustricus relative, the Iron Duke-for an hour's drive, and had just pulled up at the "White Hart," at Hook; and then see come rattling along, at ten or twelre miles an hour, the "Southampton Telegraph," with four "spicy prads," not to be matched in colour, not going at any measured pace, but all well in hand, with their heads up, slashing along under the skilful management of the then celebrated John Peer, who sits at his ease conversing with his box companion, or turning his head to answer some query of a passenger on the roof, with whom his titled compeer intended to have a minute's chat that morning. But no-the "Independent" is close at his hind boot, and John can only acknowledge his Lordship's condescension by a slight but well-timed obeisance in passing. Compare the two, I say, and then judge if the eye would not cease to be captivated by the racant splendour of the nobleman's equipage, and follow to its utmost ken those two rival (one almost matchless) and admirable specimens of this useful, elegant, attractive, but now almost obsolete art.

Before I leave this part of my subject it will not be deemed irrelevant to say a little more of the unsightly machine that but few of my readers can remember, as it was just going out at the time I commenced life; therefore would they scarcely recognize the purpose for which it was intended, or believe that this rude invention of our fathers was made use of for plundering the simple and unwary.

${ }^{1}$ The late Duke of Beaufort, then Marquis of Worcester. 
The improvidence and recklessness of our seamen, as regarded their hard-earned pecuniary remuneration, is well known-for these have not quite passed away; neither are we likely to forget the swarms of Jews and infidels of both sexes constantly lying in wait to pounce upon the unsuspicious sons of Neptune, to ease them of the light but seductive burden they had been supplied with, after year's of toil in a distant and sultry climate.

It would naturally be supposed that, after rumning the gauntlet of our seaport towns, they would be safe from any further depredations. Not so-as the following anecdote will show :-

Many years after I left the place of my prosperity, while on my last stage, business or pleasure called me down to my native county, and on my return I got on the box of the Godalming coach. In the coachman I recognized a very old servant of my father's. After expressing, not in the politest terms, his pleasure at seeing me again, he began conversing on the hardness of the times, comparing them with days of old.

"Them was the times, when I drove the old Blue for your father out of Portsmouth. Why, I have got more money in one night than, I fancies, you does in six months."

"Why, how was that?" said I. "I always understood that sailors never gave anything to coachman or guard.'

"Give anything: We didn't give 'em a chance."

"Why, how did you manage, then?"

"We used to set 'em a-fighting in the rumble-tumble, when they'd be sure to drop something worth picking 



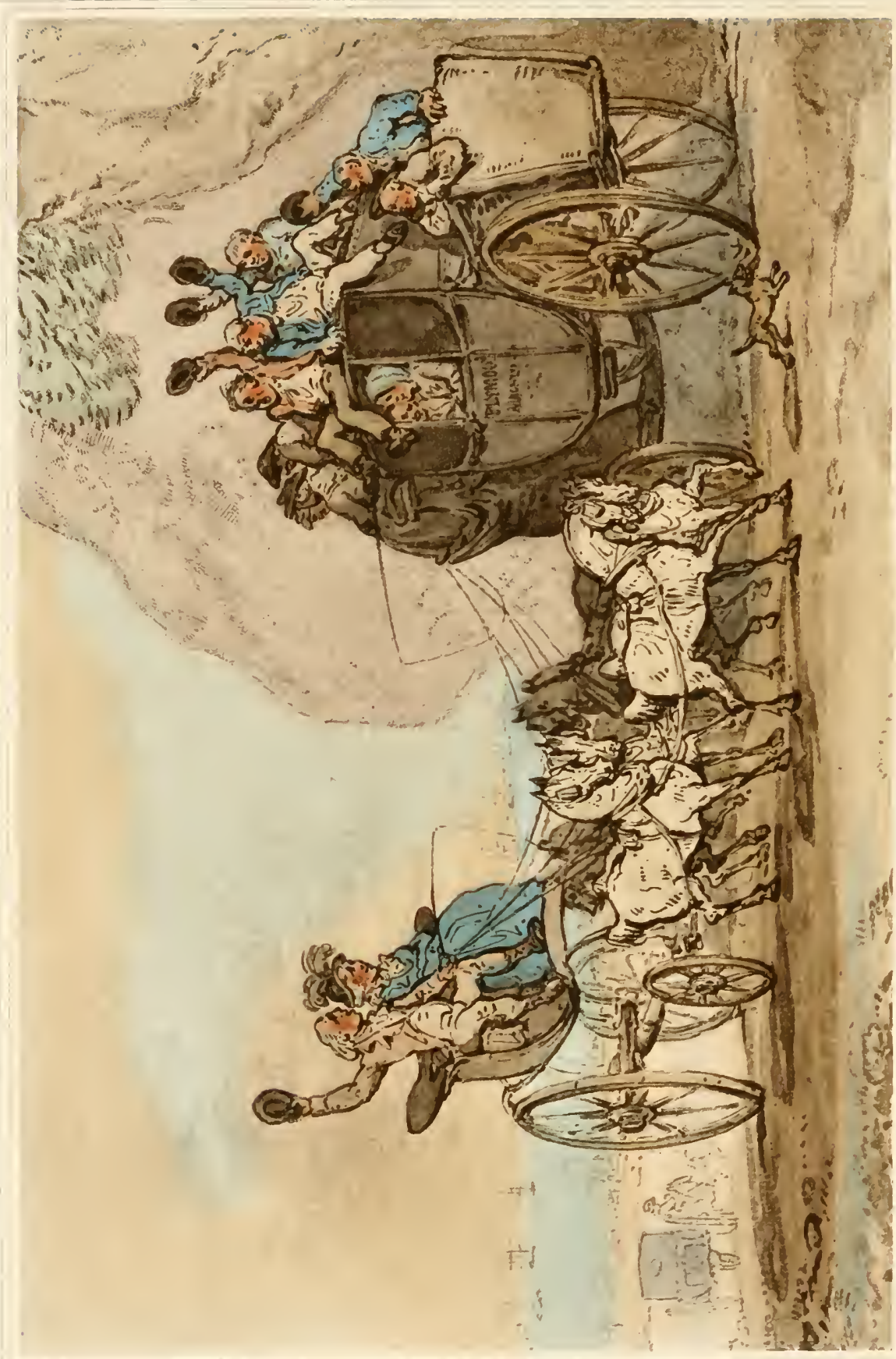


up. Some of 'em would carry their blunt in their hats; and one night there was a fellow had got ninety pounds, all notes, tied up in a roll; and old Bob Chandler was guard of the old Night-coach, and give me the office, when we pulled up together at the Hammer Ponds. Going over Rodborough, Bob contrived to knock the fellow's hat off, when I got down and picked it up; and on our arrival at London old Bob and I went snacks. There's no such times as them now."

I could but stare with indignation at this fellow's villainy and shameless audacity.

I add a further proof of the facility there was in imposing on these simple-minded people.

The Portsmouth Night-coaches changed coachmen at Godalming, in Surrey-the mail at Mousehill, a village two miles nearer Portsmouth; consequently, there were two of the fraternity every day at each place, with their time totally unemployed. On one occasion the two from Godalming walked over to Mousehill, as was their custom in fine weather, to play a game of skittles with their brethren, or otherwise amuse themselves. On their reaching the "White Horse," they observed the daycoach about to pull up, laden with sailors on the outside.

"I'll bet you a beefsteak for the four," said one to the other, "that I will draw one of these sailors of a pound."

"A done," said the other, who was a much younger hand than his friend.

The coach stopped, and the coachman dismounted and went into the bar. 
"Give me your way-bill, coachman," said the one who had made the bet, at the same time giving him the wink. Then, addressing the first sailor who had entered the house- "Holloa, you sir! you have not paid your fare!"

The poor fellow replied, with an oath, that he had.

"What's your name?"

"John Scott.

"I don't see that name," said he, looking over the way-bill. "You must pay, or you can't go any farther."

"How much is it, then?" said Jack.

" One pound."

"Take it, and be d-_ ! " the man exclaimed, as he threw down the note, which the other pocketed, and thereby won his bet.

That fact accomplished, the money was returned; for though of the old school, W. Bishop was not the man to participate in such vile practices; and I have recorded it only to show how easily sailor's could be duped, as well as to show how these poor fellows were rewarded when returning to the country which their undaunted bravery and unwearied toil had preserved.

The means practised by crimps and touts were in a far more wholesale way; for they would not only take the money of the sailors, but take care that many of them should never see the coach, which, leaving with half the complement they had booked, would find a lot more waiting, in charge of these worthies, at a house two or three miles on the road, and they, rather than not go, would clamber up, after having been induced to reward 
their kind offices, in thus procuring them a passage, with more than double fare.

With these improvements, then, in the style of both man and cattle, constantly passing before my eyes on the one hand, and the threats of poverty assailing me on the other, I began to consider seriously of the proprietyindeed, of the necessity - of adapting myself, my inclinations as well as my circumstances, to the times.

The serious losses I had sustained had already compelled me to dispose of the greater part of my coaching business; and the dockyard contract, which had turned out a good paying concern, but, requiring daily attention, I was also obliged to make orer to my partner, for which I received a small premium. I still occupied my farm-but this did not sufficiently occupy my time; and now, having but one coach left of my extensive establishment, I thought I could not do better than save myself the expense of a coachman, and reap the rewards the box afforded. Besides, from the domestic aftliction I was labouring under, I wanted something to fix my attention and to dirersify my thoughts; and my undertaking to drive my own coach offered the best-indeed the onlymeans within reach of supplying the deficiency, as stated hours of employment would do the one, while the daily change and rariety of company would induce the other.

It was on the Portsmouth road, then, that I first made my debut in the character I have assumed in my titlepage; and although I did not remain there long, for reasons which I shall presently relate, I continued my career in the profession with but little intermission until railroads put a stop to it altogether. 


\section{CHAPTER XI}

THE POR'TSMOUTH ROCKE'T

Ambition-The Beetle-Loss of Caste-The Brighton Road-Box Companions - A Naval Hero-Sporting Colonel-R. B. Sheridan-New Friends-A Race-The Result-Fog-Singular Appearance-Talkative Companion-A Spill-Scene in the Bere Forest-Unrewarded Friends-Experience-An Exeat.

WIIATEver the philosopher may imply, or however the cynic may deride, it must be conceded that ambition forms part of our existence; it is wound up in all our thoughts, words, and actions, and is as much the moring power of those engaged in commercial pursuits, of whatever grade, as it is of either of the liberal professions.

It would be a difficult matter to decide whether to place it in the category of our virtues or our vices, for it is an allurement both to the good and the bad, of every age and nation. It is a deity that is worshipped alike by the warrior and the priest-the statesman and the poet - the lawyer and the doctor, in the higher sphere-the mechanic and the merchant-the industrious and the idle-the honest man and the thief, in the lower.

All sacrifice at its shrine, all are eager alike to mount its ladder, and all are subject by a false step to fall "e'en 
from its topmost round." In vain, then, has our great bard said,-

"Cromwell, I charge thee, fling away ambition!"

It was ambition that made that quondam butcher's boy, into whose mouth the poet put these words, a priest and a statesman, and by his talents and intrigues a ruler of sovereigns.

It was ambition, instigated by religious zeal, whether real or assumed, aided by the most consummate art, that subsequently enabled a private gentleman of Huntingdon to obtain supreme porver, to subvert an ancient dynasty, and to govern by his own strong head and arm.

It was ambition made a Corsican advocate's son an Emperor, and the scourge and curse of Europe. It is ambition that makes literary aspirants cabinet ministers. Ambition makes a clever mechanic a millionaire-an industrious journeyman a wealthy and prosperous master. Ambition also makes members of parliament of fortunate speculators and successful adventurers-and gentlemen of swindlers; and maybe 'twas ambition, "though not the true one." that made coachmen of gentlemen and nobles.

It was then the ambition of the humble individual now inditing these pages to become a great coach proprietor. From his father's position at the head of one of the largest establishments in London, he had an opportunity of contemplating the importance, the status it gave a man in society; and comported himself accordingly, to acquire a knowledge of its relative duties and advantages.

It will be recollected but by few, I fear, of my readers, that the coaching world was comprised in a circle, and 
that each large establishment was a little kingdom of itself-that each particular road was a territory that perhaps jointly, perhaps solely, became the right from long usage of this or that establishment, and any infringement of such right was considered an offence, and immediately met with retaliation.

The general result was open and declared hostilities, in the shape of opposition coaches, going at a more rapid pace and at reduced fares, terminating frequently in the ruin of one or both parties.

It will not then be difficult to divine that it required a good general, that is, a man with a good capacity, of keen judgment, and, what is more, of considerable caution, to preside over such an establishment; for he had to seek and secure alliances among the different country proprietors, and to hold it in his power to reward the allegiance of one, or punish the delinquency of anotherall of which involved tact, penetration and forethought.

For want of these my poor father fell, and, in his fall, crushed the rising aspirations of his more ambitious son, and blotted them out for ever. It would be worse than a foolish vanity to compare this with the fall of those brilliant stars of greater or less magnitude, whose careers are emblazoned in the pages of history; but the effects on the individual are the same as is so truly depicted in the lines emanating from a spirit that could so justly appreciate the beatings of the human heart, in the lowest as well as in the highest condition :-

"And the poor beetle that we tread upon, In corporal sufferance feels a pang as great As when a giant dies." 
I must claim the reader's indulgence for thus expatiating upon the change of my circumstances; but such reflections form the necessary comnection betreen my previous and then present position, and the feelings they gave rise to are brought more forcibly to my mind by the scenes I daily see around me.

Many were the opinions passed among my own acquaintances and friends, as well as the public generally, upon the step I had taken, which was lauded by some, condemned by others, and excused by all, who best knew the real cause of my entering upon so formidable an engagement-formidable in the responsibility of having so many of His Majesty's lieges daily entrusted to my care.

In my orm estimation, I felt that I had lost caste, but for this I hoped the novelty of my new way of life rould impart compensation; and as driving was daily becoming more fashionable among the higher class, I foolishly thought I was only following in the wake of others far above myself in rank and station, and should, therefore, have them to share my degradation.

It would not be possible to enumerate all, nor would it be necessary to name any of those men of rank and title who forgot their birth, and what was due to their connections and position in society, to figure in the capacity of dragsmen. The Brighton road was the chief locale for these distinguished ornaments of the profession, and of printsellers' shops. They have passed awaytheir occupation has become roid; and the swift torrent of the rail has swept them from the public view. Some returned to their patrimonial estates, and exercised the office of magistrates in their own district, after having 
subjected themselves to a similar tribunal in others; some finished their career before the devouring flood arrived; and one in particular ( - Stevenson, Esq.) who, from necessity, made the profession his choice, after being at the University, and who, amidst all the profaneness of the calling, preserved the character of a gentleman, was

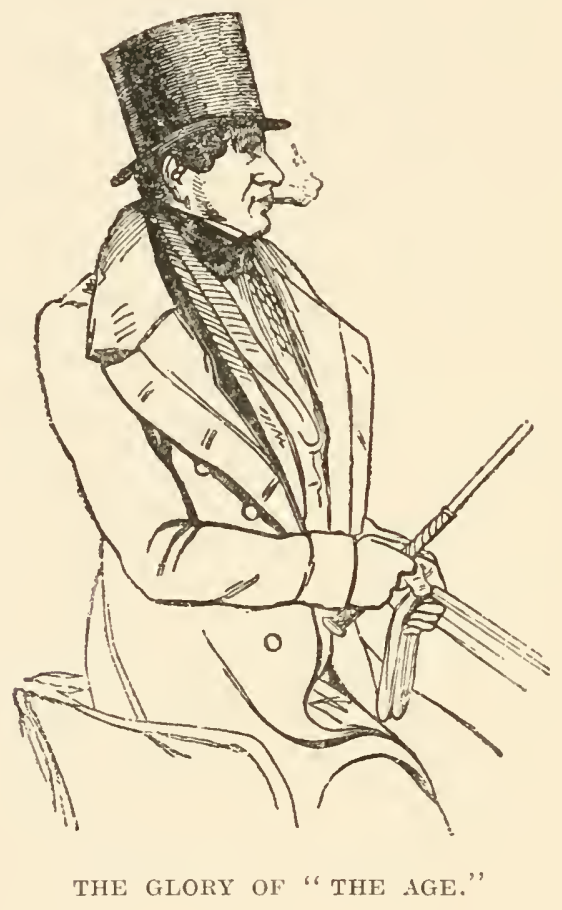

cut short by the hand of death. But the Brighton "Age" still lives in the memory of his friends, and is transmitted to posterity by the pencil of Herring.

It was at the latter end of the summer of 1816 that I commenced my new rocation. The coach which left every morning at nine o'clock I horsed myself half-way to London, where, at the "White Lion," at Mousehill, a 


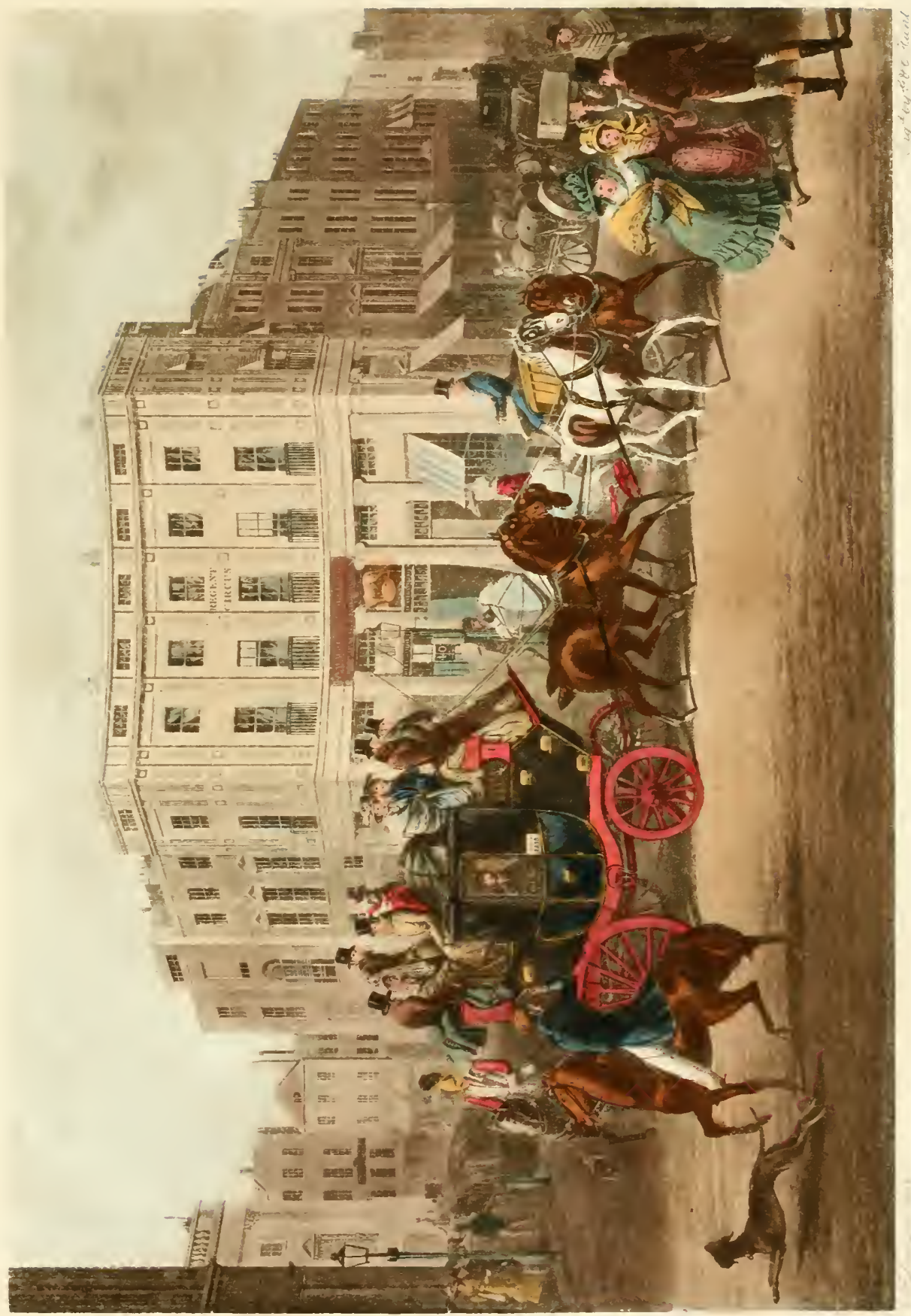

年, 

village about two miles south of Godalming, I met the down coach, and, after partaking of some refreshment, each driver turned back. My time of arrival at Portsmouth was seven o'clock in the evening-so that the houl's were about the best that could be chosen; and consequently, as the roads were very good, though rough, the work was light.

To make use of an old simile, like a child with a new toy, I was pleased for a while. There is something-but what it is I never could discover-that induces your companion on the box-should you have one-to enter into conversation; and that not always upon general subjects, but upon something appertaining to his own profession, or his family, his birthplace, or a scene in which he himself has played a prominent part. He will describe a law-suit, a speech in parliament, his introduction at Court, his first appearance at the fives-court, the management of his tenants, his travels abroad, or the number of his pheasant.

Such topics would at once announce to you that your companion was an aristocrat of the highest order, and you would listen with profound attention to the many wonders he was condescending to unfold to you. But there were persons of all grades, whose profession and station in life you could readily ascertain from their conversation.

It is said of Sheridan, the great wit, orator, poet, and playwright, that he once made a bet with one of those exalted nembers of the senate with whom he then frequently associated, that he would tell any man's calling, howerer much a stranger he might be, by his 
conversation, when and wherever he came in contact with him.

The wager was closed, and he met the individual selected to be the object of his experiment at a grand dinner-party. The cloth was cleared, and the company, consisting of the greatest wits of the day, were eager to witness the skill and penetration of their friend. The conversation became general, and the stranger acquitted himself like a man of rank and fashion, seemingly possessed of every accomplishment; every topic he discussed with apparent ease and eloquence-so much so, that the wit, who had tried erery means that the shrewdest intellect could derise to extract the kernel from the shell, found himself beat at his own weapons.

As the morning advanced, all his efforts became fruitless, and he was about to gire up in despair and acknowledge having lost his wager, when the stranger, who had been made acquainted with the secret of his being invited to meet this man of acute penetration, rose to take leave of the company. He observed that he could but testify to the pleasure he had experienced in the company and conversation of so distinguished a man as Mr. Sheridan, and should be most happy to continue an acquaintance so pleasantly began.

"I have," he added, "a pretty little spot on the skirts of the town-"

"Where, sir? - the slivts" of the town?" cried the wit, in a tone of exultation. "A tailor, a tailor, I'll be sworn!" The truth of the guess was admitted, and the wager won.

I must confess myself to have been very much enter- 
tained at times with this sort of conversation, which would lay open family secrets, intended family alliances, friendships, liaisons, disagreements and disputes in very high quarters -in one of which I remember the character of a cabinet minister, or his brother, was very seriously attacked. Such gossip, I say, amused me, and through a long career has been chiefly instrumental in rendering tolerable the daily drudgery of the employment, by relieving its monotony.

The only two companions of the former description I was honoured with during the short time I performed on that stage, that I can recollect, was the hero of Navarino, ${ }^{1}$ but then just returned to England in command of the Blalie, 74, in consequence of his promotion; and his very fine appearance, and manners, and conversation, at once convinced me that I was in company with a first-rate specimen of humanity.

The other joined me at Petersfield one morning, coming from Up Park, the magnificent seat of Sir Harry Featherstonehaugh, Bart., about three miles distant, and was then, or had been, in command of a crack regiment of Hussars. I remembered having seen him at the dinner given by the officers to their illustrious colonel.

He was a tall, long-legged man, and had a brace of greyhounds with him. Our conversation ran principally upon the merits of that portion of the family of the canine species, with which he was thoroughly acquainted; nevertheless, it did not require the eye or ear of a Sheridan to perceive that his time had not been devoted

${ }^{1}$ Vice-Admiral Sir William Codrington, Bart.

VOL. I. 
wholly to hunting and shooting, or that his associations were even of the very highest order ; altogether, he might be set down as a fair specimen of the followers of the court of the Regent. ${ }^{1}$

It is not my province to pass judgment upon persons I met, as it were, by accident; but it was my fortune to fall in company with many distinguished individuals, and it was my inclination, also, to know something of them. I am thus able to pass in review a great number of characters who have rendered themselves more or less conspicuous on the world's wide stage.

After having made choice of my arocation it naturally followed that I should, now and then, mix in company with some of its long-standing professors, nay, it was impossible to aroid, as it were, becoming one of them; but, as I had known most of them before, it was a matter of some little difficulty, and it required some little tact to lower myself to their level, that is, to render it consonant to my feelings-to which, in truth, they were quite indifferent, with the exception of one or two, who never lessened in their respectful conduct towards me.

There were two other day-coaches on the road, but as they left Portsmouth at different hours, there was no fear of our coming in contact. With the down coaches it was different, as from their leaving London by different routes, and other circumstances of stopping or not stopping to dine, would sometimes in the middle of the journey throw us together.

It happened on one occasion that on my return I overtook the other day-coaches at the "Anchor," at Liphook,

${ }^{1}$ Colonel Leigh. 
a house I have before spoken of, where they changed horses and dined.

I stopped to leave a passenger or parcel, when, as the drivers were sitting with a bottle of wine before them, one of them asked me if I would take a glass; I assented, and the bottle was soon emptied. I called for another, which was as quickly despatched, but they would not suffer me to pay for it. While hurriedly tossing off the last glass, one of my companions asked me what time I intended to get to Portsmouth that evening, at the same time I observed he gave his companion a wink. Having answered, much about the usual time, I left. They too were then ready to start, and as I had to change horses about half a mile further down the village, I drove off. While I was changing, both passed at a swinging pace, looking round and smiling, as much as to say, as I thought, "Come along." Nothing loth, I mounted, and taking hold of four, all nearly thorough-bred tits, I was soon after them.

Now, the road from Liphook to Petersfield, to speak plainly, is all up and down hill, the two steepest being at the end of the stage, and at that time it was extremely hard and rough. After ascending the first rise, I saw my two opponents, one a little in advance of the other, full a mile distant, seemingly going very fast. I put my little thorough-bred ones into a gallop, and as the road narrowed in places, I had to mark in my mind where I could or should pass them.

The first, the "Regulator," I overtook going up the hill out of the village of Rake, and passed him with the greatest ease; and the other, the "Hero," I could descry 
full half a mile before me. I knew very well I had the best team. I therefore followed at full speed. Being light loaded, the deflection of the springs corresponding with the unevenness of the road, the only passenger I had behind, a soldier, was tossed up and down like a shuttlecock from a battledore: so much was this the case, that I kept continually looking back to see if he were safe.

At the top of Sheet Hill I overhauled my competitor, as the sailor would say, and we went down the hill broadside and broadside. When nearly at the bottom we met a postchaise, whose driver, staring with astonishment, pull into the bank to let us pass.

A turnpike being just ahead I pulled in, or I do not know what might have been the consequence-but knowing my rival must be nearly beat, I marked the spot on the opposite hill where, as I thought, I could easily pass lim. I did not know, though $T$ might have known, the nature of the man I had to deal with.

Upon rising the hill my leaders were again at his forewheel, when the only inside passenger he had put his head out, and in a most angry tone, gesticulating violently at the same time, said,-

"If had a pistol, sir, I would shoot you!"

"Put your b- old head in, do!" said his coachman, and immediately pulled his horses right across my leaders' heads, driving them up a steep bank, into which the off fore-wheel stuck.

Luckily no strap, or trace, or buckle was broken or displaced, but the delay necessary to put the leaders straight, though short, was enough to allow me only to 


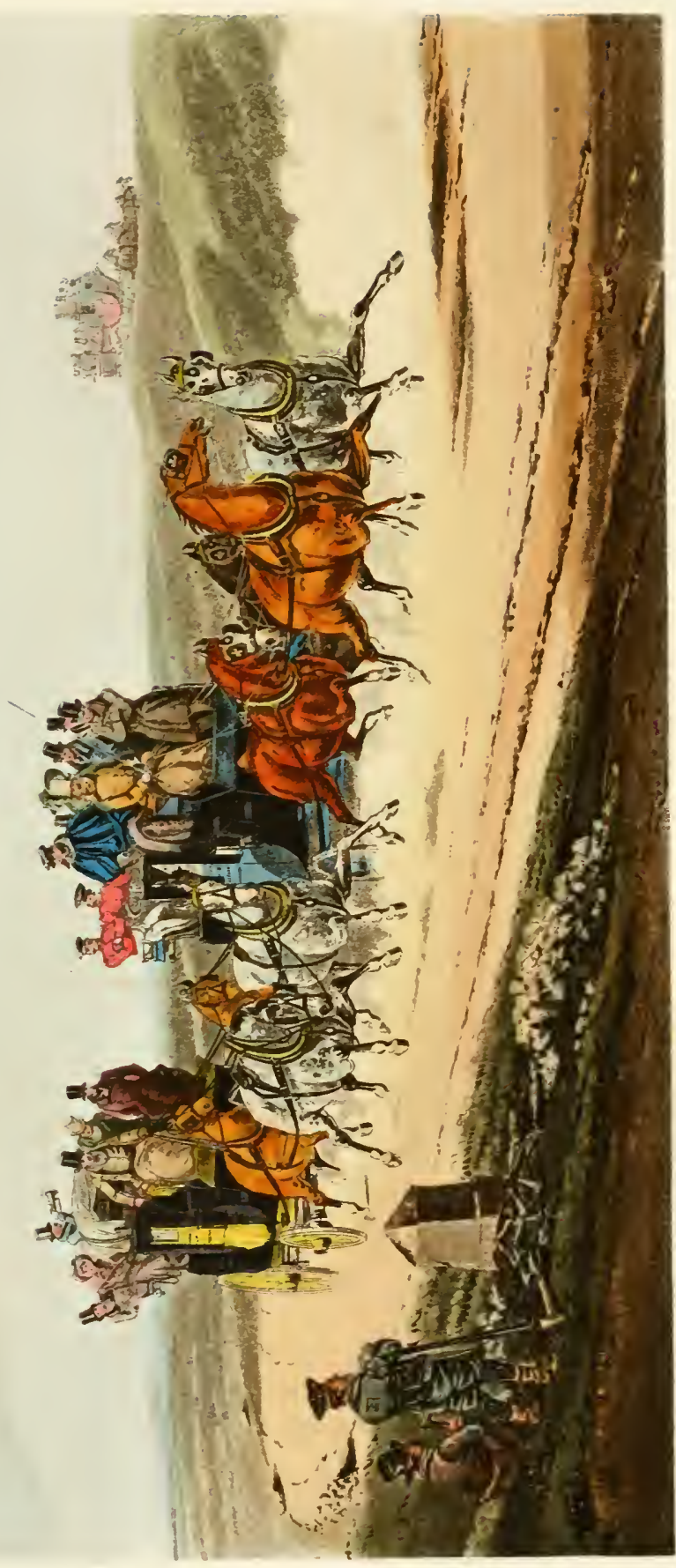

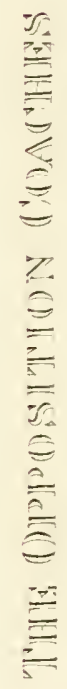




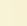


reach his hind boot when he pulled up at Petersfield. And thus ended our eight-mile course, which was accomplished - by the watch of my box-companion, who enjoyed the sport beyond anything - in a few seconds over twenty minutes.

Although my horses were none the worse for the race, they being light, spicy well-bred animals, fit for that stage, and that stage only, three of my opponent's four never came out of the stable again. $\mathrm{He}^{1}$ was a most powerful man, as well as a very superior workman, but of such a temper, that I believe-indeed he afterwards so acknowledged - he would have risked his own life as well as the passengers' before he would have let me pass him.

The result of this, my first attempt at fast driving, did not redound much to my advantage. The town of Petersfield was up in arms against the rash and inexperienced young man who could so endanger the lives of his passengers; and as my father had lived among them many years, the principal gentleman or magistrate thought proper to write to him on the subject.

The proprietor of the "Anchor" at Liphook, too, who had suffered most severely from this spirited contest, wrote to him a long letter of complaint. The consequence was, I had a business-like but parental admonition, which did not tend to make me further in love with the profession I had adopted, or to render me more inclined to support the gibes and taunts of my old associates.

However, this, like most other occurrences of a similar

1 This poor man, whose name was Abraham Titmuss, was killed not long after this by the axle-tree breaking. 
nature, was, in the course of a short time, remembered only as an extraordinary feat, and things went on pretty well till the middle or latter end of January. It was a rime frost, accompanied, or followed, by one of those thick and lasting fogs so common in this climate. I was on my return, and had for my companion on the box a man I had long known as an old inhabitant of Portsmouth; he was a respectable tradesman in the town-a boot and shoe maker-but better known as a man whose extraordinary volubility would not unfrequently rush, uncurbed, into the regions of fiction.

The display of this very agreeable gift or acquirement had not been at all lessened by the small potations he had imbibed on his way from London; for it was extremely cold.

We left Mousehill without any appearance of the fog dispersing; and on our reaching the top of Hindhead, the scene was most singular and peculiarly romantic. We seemed to be on an elevation in a small island looking down upon the sea: the sky above us was beautiful and clear, without a cloud to blot or to destroy the serenely blue concave; while the trees that reared their heads above the edge of the Bowl were adorned with icicles that hung down like crystals projecting from a rock, with equal grace and brilliancy. It was not long before we were again in this immaterial ocean, and, after sipping a little to arm us against the cold when we changed, we quitted Horndean, and entered the Bere Forest. As the erening advanced, the fog increased, and my friend's rolubility by no means decreased.

At an unfortunate moment, when he had distracted 
my attention by his unceasing tongue, I found the coach a little off its equilibrium on my side. To restore it, I whipped the off-wheel hor'se, when a noise like the report of a cannon, and I on my back, made me aware of the consequences of inattention.

I was on my legs in an instant, and soon sufficiently recovered my senses to ascertain that I was unhurt and near the spot where, but a few years before, I had had a narrow escape with my life on the runaway mare.

There were four young ladies inside, all of one party, who were soundly asleep when the accident occurred, and they innocently asked what had happened.

After extricating them, and disentangling the team, I left three of them in charge of my valuable and voluble fellow-traveller, who had, like myself, received little or' no injury, and mounting the other horse galloped to the residence of my brother-in-law, about a mile and a half distant, to obtain assistance. This was immediately granted, in the shape of three or four stout labourers and a strong cart-rope, but on our return to the scene of my misadrenture I found the coach upon her legs and in the road, the ladies again in the inside, and only waiting for me to put to, and proceed on the journey.

In this part of the forest was a plain or large dale, that afforded scope and shelter to number of those wandering people whose virtues are the theme of some of our first writers of fiction, though in real life these are exhibited chiefly in the hen-roosts and dovecotes of the neighbouring farmers. Hence the quick and workman-like manner in which all things had been put right. After thanking the motley group of males and females, children and 
adults, I proceeded on my journey safely to the end, arriving a little less than an hour beyond the usual time.

Ruminating on the accident, our harmless escape, and the ready assistance we had received, it struck me that I had neglected to reward the good people who had so promptly and so efficiently put forth their exertions in my behoof; but in groing to unload the hind-boot, I found that I need be under no uneasiness on that score, as, anticipating my forgetfulness in the hurry of departure, they had rewarded themselves with two or three baskets of game that I had taken up at Liphook, deeming pheasants and hares a greater treat to them than to the people to whom they were addressed, or their friend, the owner of Hollycombe; and eren for this I had to be thankful, for had they made choice of one or two of the ladies' trunks for a reward, I should have had much more trouble in restoring them, or finding an equivalent, than I had in paying Mr., afterwards Sir C. Taylor, for his game.

It was a maxim of one of the oldest London proprietors ${ }^{1}$ never to employ a man who had not had, at one time or another, an overturn-for this plain reason, not having such experience he would not know how to get a coach up again; I, although not possessing this valuable knowledge, could now take credit for it.

This, without creating any very great cry to my disadvantage in the town-for the fog and the darkness of the night were extenuating circumstances-called forth the strong remonstrances of my father, who was still

I Mr. Roberts, of the "White Horse," Fetter Lane. 
the London proprietor ; and elicited, at the same time, the dislike my family had to my remaining in such a situation.

But, however, this, like the other little faux pas, was soon forgotten. In the meantime, I began to grow weary of my occupation. The coach, like all others not now supported by the war, loaded light during the winter months; the passengers, some above, some below, generally offered me the gratuity, and I was not sufficiently initiated to ask for it.

My landlord offered to relieve me from the lease of the farm, knowing full well that the capital I had expended would soon invite another tenant. Not being enabled to indulge in my former amusements, without neglecting my daily business, I resolved to leave the neighbourhood; therefore making both the farm and the stock of horses, harness, \&c., over to my father, I bid a long farewell to my native county, resolved to seek in the metropolis employment on some road where I was not known, to await the chance of some incident likely to restore me to my lost position-a very vain and foolish expectation. 


\section{CHAPTER XII}

\section{THE CROWN PRINCE}

Amor Patrix-Domestic Arrangement-Emery-A Revolution-Education-A Swell Dragsman-Contrast-Leamington-A Proposition-Warwick Castle-Stoneleigh Abbey and Kenilworth-An Agreeable Surprise-A New Start-Idle Hours-A Country Walk-Gorhambury-A Pleasing Adventure-Sir Harbottle Grimstone and Lord Bacon again-Reflections and a Reflection-An Invitation-The Consequences-A Scene at South Mimms.

If there be one feeling more common to our kind than another, it is that of attachment to one's native place; and leaving it generally creates regret. This applies, perhaps, as well to individuals and families as to nations; though among the latter it is more remarkable, inasmuch as it is strongly developed in the uncivilized portions of our fellow-creatures. History and experience teaches us this.

The Esquimaux cannot be prevailed on to quit the desolation of his frozen regions; the Negro sighs for a return to the pestiferous vapours of his tropical clime; and the Bedouin exults in the deadly blast of his arid desert. The more polished member's of the human family, who boast of a superior knowledge of the great Author of the Universe, and profess, if they do not practise, doctrines deduced from His revealed will, have long enjoyed the benefits of a social and commercial intercourse with each 
other, and have found a home in every clime, even in the most distant parts of the globe; yet with all the advantages their moral condition and physical constitution give them, whether luxuriating in the voluptuous pleasures of the east, or penetrating with indomitable courage and persererance the recesses of savage nature in the west-also cherish a vivid remembrance of the home of their fathers, and a proud regard, if not a latent hope for, a return to it.

Now, it is no affectation to say that it was with some such feeling as this I left my native county. It is true, I was but little remored from it; but as for again enjoying the society to which I had been accustomed, or indulging in the pleasures her beautiful hills and dales afforded me, I might as well have been in the Bush in Australia-for even there my thoughts could only revert, as here they have never ceased to do, to times and scenes of the past.

As my father still retained one of the minor establishments in London, and had a residence there, I made it my home. My mother I found in declining health, and principally for her benefit, my father proposed taking a house at Leamington, in Warwickshire, vainly hoping to stay the progress or alleviate the agony of a disorder, the cure of which was impossible.

As the only coach to this place, celebrated for its mineral waters and the beauty of the surrounding country, was from our yard, at my father's desire I went down, and of course became acquainted with the proprietors on the road, and those of the fraternity who figured on the box. 
I had not as yet acquired sufficient knowledge of the moral merits of any individual engaged here in the Coaching business-for this plain reason, I had not associated with them long enough. In my own locality, and in my father's establishment, I had hitherto known them only as servants or inferiors, and therefore could know but little of their habits or character when off the box.

It is true I had heard of one or two who had visited the antipodes on Government business (loilie), as Emery used to say, in the character of Tylie, in the "School of Reform"; but this might have happened from a misconstruction of the law of meum and tuum, to which all were liable; or, at any rate, from the different interpretation given to it by master and man. The causes of such a distinction I therefore simply thought, could not apply to any of those noted practitionel's whose company was sought, and dress and manners imitated, by gentles and nobles, and who indeed appeared to me to be as much beyond such vulgar imputations as their employer's.

As I am now about to speak of some of the members of the fraternity, it will not be considered out of place if I here give a slight sketch, or general outline, of this sect of the community as it at that time existed - a time of transition, be it remembered, from the old school to the new ; from the votaries of gin and beer-from those who delighted in the pully dews of the morning - to those who basked in the noonday sunshine of Sherry or Moselle; from the old box-coat, with its hundred capes, slouched hat, and huge bare chapped hands, to the cape and Mackintosh, nobby tile, and white gloves. 



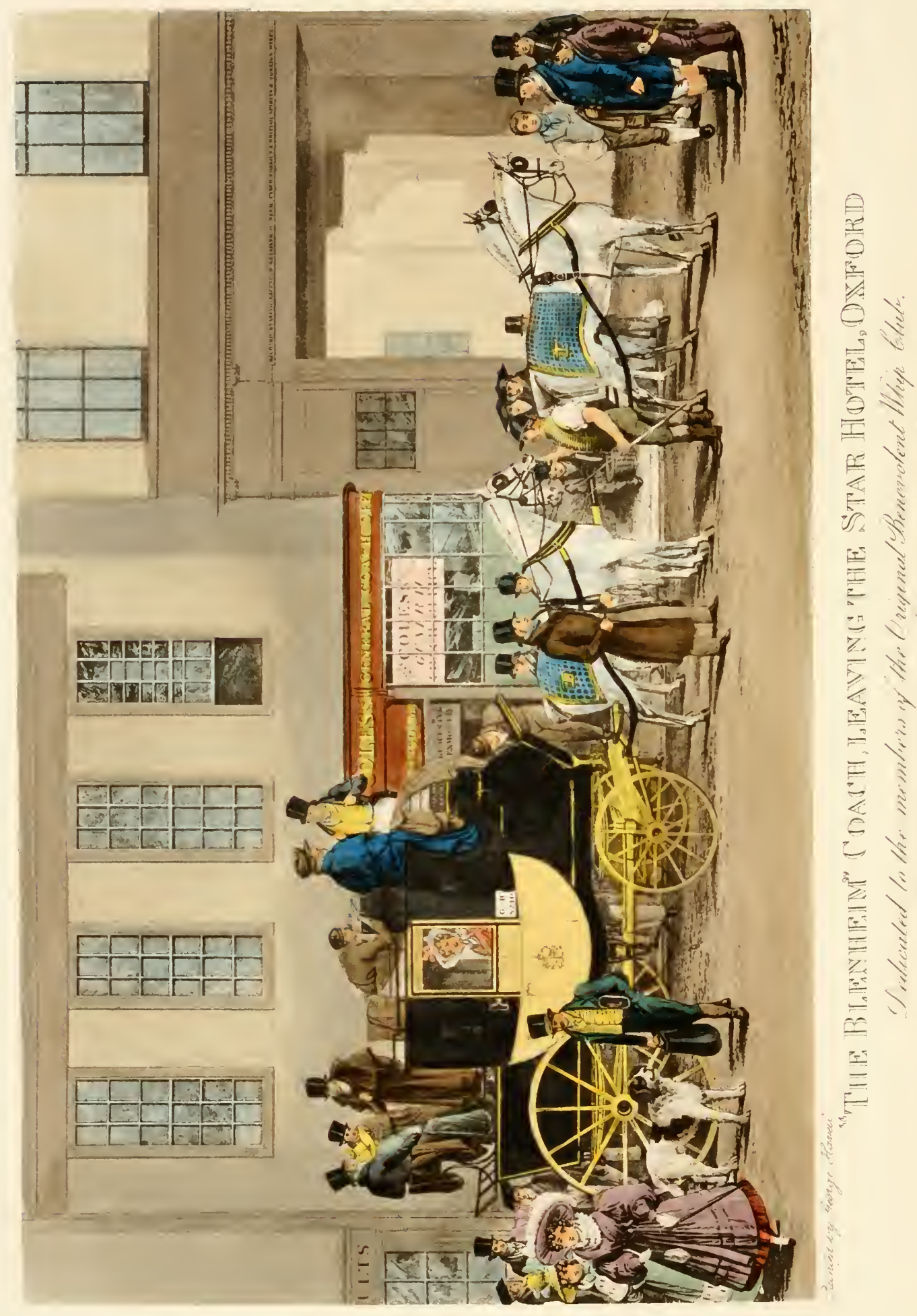


I have in a former chapter given an account of the peculiar sort of depredations committed on the poor sailors, with which I was after'wards made acquainted; these, though no doubt common, were confined to one or two particular roads.

But the old school had passed away with the clumsy vehicles, and coarse and vulgar members of the cloth, fit only for an ignorant generation; and another and more accomplished race of men had sprung up, with the improred or new-invented carriages, faster pace, and better accommodation, that the changed circumstances of the nation, from war to peace, and the consequent improvement in trade, manufacture, and commerce had put in requisition.

In most parts of the country, and on roads of 100 miles and more in extent, which led principally to manufacturing towns and districts, innkeepers were the principal proprietors; and the employment falling mostly in the night, the drivers were generally selected from their own stable-yards; and it was considered a promotion to put a postilion on the mail, who was afterwards advanced to one or other of the coaches on the same line of road.

Not so with Brighton, Oxford, and other towns at the distance of fifty miles or so from the metropolis. Here a more dashing professor was sought, to give a more attractive appearance to the whole turn-out: and to those places men who had gained some little notoriety, by their superior skill and strong nerve, resorted for employment. At this period, and for some time before, the whole business in the last-named place had been in the 
hands of one man, who had inherited it from his father or uncle; and, under the masterly superintendence of Richard Costar, Esq., Oxford set an example to the whole kingdom, and acquired a celebrity for the advance it had made in the general improvement of public conveyances.

In this school, and under this gentleman's fostering protection, some of these men had thrived, and afterwards showed their gratitude by leaving his service, and becoming the principal instigators of a competition,opposition it may more properly be termed,-which gained them a celebrity many of the more youthful professol's were anxious to acquire. These men, and such as these, were sought by the London proprietor's when they started any new coach, whether in opposition, or to some newly-discovered fashionable watering-place.

About this time, too, a sort of flash language, called slang, was very much in use, and it was considered almost a necessary accomplishment, and a recommendation for employment on the box, although the candidates had picked it up in the purlieus of St. Giles's, and among associates who were now and then unwilling pleaders at the bar of the Old Bailey. It was not then thought necessary to know anything of the moral condition of the man-whether he were the husband of one wife, or lived in the grossest immorality. A good outward appearance, plenty of confidence, and a notoriety, it mattered not by what means, or at whose expense, acquired, were qualifications sufficient to obtain employment in the first establishments in London; whereas the same qualifications might, and did, cover other's that should have conducted their possessors to the penal settlements. But it will not 
do to look too narrowly into the characters of our public men, in whatever sphere they may be placed, or the country would lose the services of many able denizens.

Notwithstanding this, there were coachmen whose aspirations did not lead them to so lofty a pitch of celebrity, and who were content to live in the approbation of their employers and in the general esteem of their fellows.

Now, upon the coach that went to Leamington, or rather through Leamington and Warwick to Birmingham, and which had been denominated the "Crown Prince," in honour, I suppose, of the French heir to the throne of Sweden, there were four men employed-one at each end, and two in the intermediate ground; and two out of the four were good specimens, though from an opposite view, of the description I have given.

The man who officiated out of London was one of those flash gentlemen who possessed all the characteristics (and would, from his appearance, at the present day, be pointed out), as one of the members of the swell-mob: indeed, that might have been his principal arocation, and this only a subordinate one, for he assumed to be acquainted with every thief in London. His stature was short, and his head protruded from his rounded shoulders like a wen; the contour of his countenance was something akin to a hawk; his eye indicative of a prowling, knavish disposition; and his whole expression was not unlike that inimitable representation of Ancient Pistol by little Simmons, as he was called. His manners were coarse, his speech vulgar, and his conversation of the worst and lowest description. His knowledge did not seem to 
extend beyond the prize-ring, and his principal patrons consisted of those unfortunate scions of the aristocracy who, not from choice, took up their residence, for a time, within certain prescribed limits in the immediate neighbourhood of the Fleet Prison, allotted them by the law. I was not a little surprised to find this man an especial favourite with the innkeepers and proprietors on the road, and was fain to attribute the dislike I had to the man to prejudice, or want of knowledge of what should constitute a respectable and desirable servant. Indeed, his natural bearing, made up of impudence, ignorance, and swagger, would convey an impression to the unthinking that he was a person of considerable importance.

Passing over the next, who was, or had been, a gentleman's coachman, or flunky, and had acquired his position, as our younger sons of nobility and others do in the army, by purchase; I come to the third, whom I found to come a little nearer to what I had pictured to myself ought to be the conductor of a public conveyance, loaded with visitor's to a fashionable watering-place. As the up and down coaches met midway, and the men exchanged seats and way-bills, the other man had told him who I was, consequently there needed no introduction. He was a fine, tall, good-looking young man, and an excellent workman. The day was fine, the company all of the better sort, and in conversation with those on the roof, he seemed quite at his ease. We dined together at Southam, and, after discussing a bottle of port, soon became on familiar terms.

Arriving at Leamington, he pulled up and put me 
down at the "Royal," and, his day's work terminating at Warwick, but two miles farther, he said that he would return and spend the evening with me. With this I was much pleased, as my father had not yet moved the family down, and I was quite a stranger.

In the meantime, I walked over this new town, that had sprung up like a mushroom. My father had told me that the house I should alight at was, in his time, the only house in the village; and that, upon one occasion, he and his partner, when he first had possession of the large establishment in London he had lately left, stopped there on their way from Shrewsbury, where they had been to establish a new coach, and, having to remain all night, they drank all the wine and spirits the landlord had in his house-a proof of the former insignificance of the now flourishing town of Leamington, with its sixteen thousand inhabitants; a contrast that a paltry pot-house afforded with some of the most splendid hotels in the kingdom.

My friend soon returned, and, in company with the host, a merry, facetious, at the same time most hospitable little man, whose society I enjoyed many times afterwards, I spent a very agreeable evening.

The consequence of that day's ride and that evening's association was, that I had to undertake to drive the London end of this said coach, of which my new friend was part proprietor.

I had not much time to consider their proposition, after retiring to rest; for the length of the ride and the goodness of the entertainment caused me to sleep very soundly. Waking early in the morning, I recalled the VOL. I. 
overnight's conversation, and, after some little deliberation, resolved to profit by it as soon as occasion would permit.

I had been offered a situation as a commercial traveller in a large wine-house in London; but having known some of these gentlemen, and observed how their habits tended to a short, though to them perhaps a pleasant life, I hung, as it were, in the balance-more particularly as the man I was to succeed was then in the last stage of diseased liver and lungs, at something considerably under forty years of age.

I did not immediately return to town, but, at the invitation of mine host, who was a capital fellow, I remained nearly a week, enjoying the salubrity of the air in daily drives - one day going to Warwick Castle, whose tall keep and old walls, with its galleries filled with portraits, and its halls lined with ancient armour; its extensive domain, as viewed from the western front or windows, gives a pretty good idea of what a feudal baron was, and brings to recollection the deeds and character of the last and most powerful of that class, whose name is illustrious in our history as the King-maker, and is the subject of one of the best productions of the best of novelists ${ }^{1}$ - - the next day going to Stoneleigh Abbey, then the seat of Chandos Leigh, Esq., who was afterwards ennobled by the title of Lord Leigh, and still holds possession of one of the most beautiful seats in the county of Warwick. Afterwards I went to Kenilworth, now a ruin, but to me not half so romantically situated or so interesting as those of Corfe, although its history is rife 1 "The Last of the Barons." 


\section{A CHANGE}

with incidents of the court of Queen Bess, and is the scene of one of the most admired fictions of the great Wizard of the North.

My evenings were spent in company with my friend, who returned from his drive about six, and daily we became more closely allied; nor did he one day omit to importune me to take hold, as he termed it, in which he was always backed by our little merry host. To this I could give no satisfactory response, as I felt considerable unwillingness to ask even my father to displace any man on my account. What was my surprise, then, when, on his return one evening, I could but observe, though always a good-tempered looking man, his eyes sparkled with unusual joy as he told me that Humpy-as he called him-was off; that my father, annoyed at his insolent and assuming manner, had summarily dismissed him, and had sent out "a yokel" with the coach, and would insist upon it that the box was reserved for me. I did not doubt the former part of his information, but the latter I did very much. However, nothing would do, inhospitable as it may seem, but that I must return with him in the morning-which I did, equally charmed with my reception and his good intentions towards me, deeply impressed with the beauty of the county, and ready to subscribe to the truth of its celebrity for good ale and pretty women.

Arrived in London, I prevailed on my father, much easier than I expected, to allow me to take possession of the box; and on the following Monday I entered on my new vocation. To speak technically, the drag to which I was appointed was the first, and continued some few years the only, day-coach to Birmingham. 
After passing through St. Albans, Dunstable, Stony Stratford, Towcester, and Weedon, it proceeded through Leamington and Warwick, turning out of the direct road (through Coventry) at Daventry, making the whole distance 112 miles.

Starting from London at five in the morning, my functions ceased at liedbourn, a large village four miles beyond St. Albans, where I had to await the arrival of the up-coach from Birmingham at six in the erening, and then return to London, which I reached between nine and ten.

With this arrangement I was by no means displeased, for the reason that ererything was new to me. I wanted change, and I had it. I was removed from the scene of my former enjoyment, it was true; but the regret for that was counterbalanced by the satisfaction I felt at being comparatively unknown in what I could but consider my present menial condition. I drove none but my father's cattle, therefore I had no blustering country proprietor to bully me. At the inn or public where I stopped at Redbourn the passengers breakfasted, so that I collected my fees without any difficulty; and though at first with some little repugnance, this was soon obliterated by the generally cheerful manner in which the custom of a spontaneous offering was adhered to. Another thing, the coach loaded well, seldom in the summer months a day passing without a full complement of passengers, and, I may say, almost all of a very genteel description; so that in a little time I became reconciled to my fallen estate, with which, no doubt, the certain 
remuneration, without any risk or outlay on my part, had much to do.

But how was I to pass my time? The many hours I should have to remain waiting for the up-coach, how were they to be disposed of? The place being a great thoroughfare, on the high road to Birmingham, Manchester, Liverpool, Leicester, Nottingham, Sheffield, \&c., the mails to those places, with many other coaches, changed horses there, and it might be called a depôt for horses and horse-keepers; consequently the inhabitants consisted chiefly of publicans, and a few small shopkeeper's and tradesmen. Many other coachmen stopped here, but none so long as myself, as mine was the first coach down in the morning, and the last up at night. At first $I$ felt this vacant time as a great inconvenience, which, however, I presently found means to alleviate by indulging in my fondness for books; and frequently, on a fine day, I would saunter about the lanes and fields with one in my hand.

On one of these occasions I found myself in what had a semblance to a gentleman's park; and, observing a rustic seat under a wide-spreading oak, I took the liberty of setting myself down and resting. I liked the spot so much-for it was on the rise of a hill, and commanded some beautiful scenery - that I repeated my visit several times, till one day I was accosted by a man, dressed like a gamekeeper, who, after asking my name, which I did not hesitate to give him, touched his hat, and departed. The next day, to my great surprise, I received a note from the owner of the mansion and park, threatening to indict me for a trespass should 
I make my appearance there again. Upon inquiring why such a proceeding was thought necessary, I found I was suspected of being in search of pheasants' eggs; and this caused a very angry correspondence between me and the gentleman, in which I did not fail to animadvert upon the illiberal construction he had put on my innocent recreation.

I should not have mentioned this slight incident, were it not to contrast it with another of a very opposite nature. Sauntering one day in another direction, after wandering along bye-paths, through fields and woods, I emerged suddenly on a green lawn, in full view of a fine mansion. It would have appeared that I was observed, for a person issued from the lower apartments, came towards me, and, raising his hat, politely asked if I wished to see the house. Surprised at his question, as well as his manner, I said (having my late error uppermost im my mind) I was sorry I had so unwittingly trespassed, but if he would be kind enough to point out the nearest way to the turnpike road, I would immediately retire; to which he, with a smile, replied, there was no necessity for that. His lordship, he added, had sent him purposely to ask me in, and show me the house and grounds, if I desired it.

"What nobleman," said I, "has done me such honour?"

"Lord Verulam."

"What!" I said, "is this Gorhambury, once the seat of the great Lord Bacon?"

"The same, sir," said my conductor.

"I had no thought that I was anywhere so near it. I should like very much to see it." 
"Then come with me, sir." Closing my book and putting it in my pocket, I accompanied him into this handsome and interesting residence, which I believe was built somewhere about the middle of the last century. The magnificent portico is supported by eight lofty and substantial pillars, with Corinthian capitals, and the elevation is in a similar style of architecture; the rooms are good though not spacious, and were replete with every comfort, and furnished in a fashion suitable to the dignity of its noble and esteemed owner. It did not contain any extraordinary work of art, and the paintings consisted chiefly of family portraits, by Vandyke, Sir Peter Lely, Sir Godfrey Kneller, Sir Joshua Reynolds, and other esteemed artists. A picture that attracted much of my attention was a likeness of one of his lordship's celebrated ancestors, Sir Harbottle Grimstone, who was closely allied to the five members demanded by Charles the First, when he went down to the House of Commons for the purpose of arresting them, and was conspicuous in and out of the House for the share he took in the proceedings on that occasion-which ill-advised act was followed by the Civil War, that finally consummated that unfortunate monarch's destruction.

Passing one room, where my conductor said his lordship was at present engaged, he took me first to the conservatory, full of a variety of the most beautiful and rare exotics: then to the forcing-houses, where multitudinous clusters of grapes hung from the roof in great profusion and perfection. I could but stop and feast my eyes on so pleasing a sight, admiring how art coủld be made to 
surpass nature, and cause this cold and cloudy clime to rival the productions of the sunny South. Leaving this place with a "lingering look behind," I proceeded to the ruins of the old mansion.

Here there is ample food for the archaologist, particularly in the small tower or entrance, which gives evidence of a date far anterior to that of Elizabeth. The ordinary observer might place its erection in the time of our Norman kings, but he would be at a loss to account for two Roman medallions on each side of the building (one of a Caesar), in excellent preservation, unless he knew that they had since been discovered in the neighbouring.ruins of Verulam, and purposely placed there.

My companion then pointed out the room which the great Chancellor generally occupied when pursuing his studies after his retirement from Court;- -when that mighty mind threw open the doors of knowledge, and founded a system of philosophy that has obtained through each succeeding generation, and has been of more benefit to his country and mankind than all the boasted and splendid productions of the ancients; or, indeed, any that have dared to soar in regions which the most powerful of human intellect alone can reach in any age or nationour own Sir Isaac Newton alone excepted.

He may have been, is now, and will be, followed, imitated, almost worshipped, and his works illustrated and embellished-by others, his highly-gifted and talented admirers-but there he stands in the pages of our history, the Jupiter Olympus of a sublime conception, masterly design, sound reasoning, and useful knowledge-com. 
bining to form a practical progressive philosophy that has earned for him a title far more enduring than any a sovereign can bestow.

But I am wandering, as I did years ago among the ruins of that great man's habitation. I turned from it with thoughts on the infirmity of human nature and the mutability of mundane affairs; and I was about to take leave of my kind chaperon, when he stopped me, and said, "His lordship has desired me to offer you some refreshment." Now, although my mind was wrapped in meditation, I was generally alive to the comforts of the body; and as my walk had been a lengthened one, measured more by time than distance, I freely accepted his invitation, and entering a pleasant apartment, I found everything prepared that could tempt the most fastidious-as well as satisfy the most craving appetite. After doing ample justice to both solids and liquids, addressing my friend, whom I concluded to be the steward, I said,-

"Nay I be allowed to ask to whom I am indebted for" this more than common mark of hospitality-to you, sir, or his lordship?"

"Oh, his lordship, most certainly."

"How should that be," I said, "when I am quite a stranger to him?"

"Not quite, I believe. Are you not the person who has lately been in correspondence with one of the magistrates, respecting a trespass you committed in Rothamstead Park?" I answered in the affirmative; he bowed and said no more.

I then clearly understood what was meant, particularly as my host and my correspondent were neighbours, as 
well as magistrates; therefore taking leave of my companion, and requesting him most respectfully to thank his lordship from me, for this especial mark of his favour, I returned to Redbourn, well pleased with my walk and entertainment, contrasting in my own mind the conduct of a man ennobled by worth as well as by rank and wealth-with that of one of mean understanding, who possessing but one qualification necessary for his position, had not a spark of generosity or gentlemanlike feeling in his whole composition.

It was not long after this, when I had, by my solitary walks, or other means with which I was unacquainted, become pretty well known in the neighbourhood, that one of Lord Verulam's tenants, occupying a farm adjoining the town of Redbourn, invited me to dinner. I accepted the invitation; and after receiving a hearty shake of the hand from my new acquaintance, and as polite a reception from his wife, a lady of prepossessing appearance and genteel manners, he introduced me to his friend, in whom I immediately recognized the gentleman who had been so assiduous in his attention to me at Gorhambury.

He expressed his gratification at meeting me again, and we sat down to an excellent repast, in which I satisfied my host that I well knew how to appreciate that part of his entertainment. After the cloth was withdrawn, and the bottle had circulated a little, it did not take me long to discover that I was indebted for my invitation to the gentleman whose acquaintance I had already so unexpectedly made at Gorhambury. It was natural that the conversation should turn on that meeting, and I learnt that the correspondence already spoken of, 
which had been read before the Bench, had attracted Lord Verulam's attention, and raised perhaps alike his curiosity and his disapprobation of the conduct of his neighbour-hence my reception at the Hall, and the gratification I there experienced.

Flattered at having made a favourable impression, I failed to perceive that the good old port, of which the host was by no means sparing, was likely to make an impression on me. Wishing, as I supposed, to mark the favour I had done him by partaking of his hospitality, and knowing my time was limited, he finished the entertainment with two bottles of excellent claret. $\mathrm{He}$ requested me not to hurry myself, as he had ordered his gig, and would himself drive me to Redbourn, a distance a little more than a mile. Nothing loth, I followed his suggestion, and swallowed glass after glass with considerable gusto.

Taking my leave of the fair lady and my friend the steward, I stepped into the gig that was at the door. I soon became conscious that I had over stepped the bounds of prudence. I was, nevertheless, in full possession of my senses, and in no fear of not keeping my equilibrium.

Arriving at the inn, I found the coach there, the hor'ses put to, and the passengers seated-the proprietor, who resided there, looking very serious; and the coachman who had brought.the coach up standing by his side, with a significant smile.

Without saying a word, except wishing my entertainer good evening, I took hold of the reins, mounted without any difficulty, and drove off, determined, as I thought, 
to be doubly particular and careful. As usual, I pulled up at St. Albans for a minute or two. I did not get off the box; indeed, I was afraid to trust myself, for I began to feel more and more the effects of the quantity, as well as the quality, of the wine I had taken. However, we proceeded very steadily and very well to the top of Ridge Hill; from thence, the worst part of the stage being over, the horses were accustomed to go the last four miles at a more rapid pace-consequently I put them on a little faster, and, passing through the turnpike-gate at Mimms, they being all very fresh, I fancied they would like a gallop; so after leaving the village, going down the little descent that opens on to the Wash, I, as the ter'm is, "sprung 'em."

I was perhaps in the middle of the road, and the fence on my off-side being very high, I did not observe the Nanchester "Cobourg" coming round the corner, at about eight or nine miles an hour-I going about double that pace. Just before we got to the turn, we met: my leaders flew out of the road at the instant, over a small ditch on to a bank, where was a lodge with a white gate leading to a residence then occupied by the Duke of Leeds. The carriage-road extended from the lodge into the turnpike, and was marked by two white posts. Inside the first my horses passed, but the sudden jerk in crossing the ditch threw me off, and I lay on my back in the road, and, for a moment, saw the coach falling on me; but in that same moment the body of the coach struck the post, and the hind wheel having spanned the ditch, she, as the sailor would say, righted; and, with the force from the speed they were going at, broke down 
the other post, regained the road in safety, and were stopped just as they reached the little bridge over the Wash :-a most miraculous escape for me.

The passengers who sat still were unhurt; but one gentleman, in jumping off the hind part of the coach, sprained his ankle, and, sore with pain and fright, he insisted upon being conveyed to London in a post-chaise. One or two of the others accompanied him-at which I could not help observing that there is generally one troublesome customer among the passengers when anything occurs, and he is always sure to be a member of the legal profession. As it was, I thought myself well off by paying for the post-chaise, and the injury done to the off-leader of the Manchester coach-my roller bolt having lacerated his shoulder to such an extent as to render him useless.

Altogether, this gross indiscretion on my part cost me $£ 20$ - an inconsiderable sum compared to what might have happened, but enough to purchase a resolution never to throw a chance away again. I assure my reader's that, in my long career, it was never repeated.

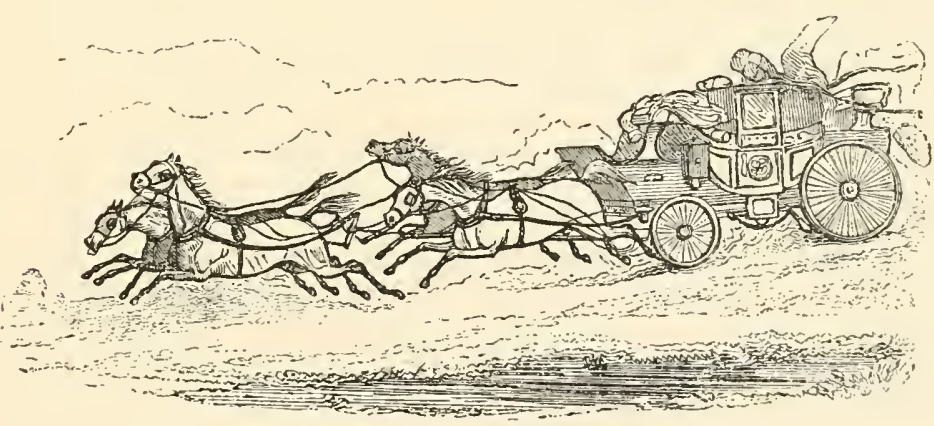

a clear stage, and No fayour. 



-

? 

veternary Library

Tufts University

School of Veterinary Midirim.

200 Westuoro Rd.

North Grafton MA 01530 
